Aus der Klinik für Zahnärztliche Prothetik

(Prof. Dr. med. dent. R. Bürgers)

Im Zentrum Zahn-, Mund- und Kieferheilkunde

der Medizinischen Fakultät der Universität Göttingen

\title{
Bestimmung der Quantität der mRNA ausgewählter Proteine der extrazellulären Matrix des Alveolarknochens mithilfe der real-time RT-PCR
}

\section{INAUGURAL-DISSERTATION}

zur Erlangung des Doktorgrades für Zahnheilkunde

der Medizinischen Fakultät der

Georg-August-Universität zu Göttingen

\author{
vorgelegt von \\ Christian Große Steffen \\ aus
}

Salzgitter

Göttingen 2016 
Dekan:

Referent/in:

Ko-Referent/in:

Datum der mündlichen Prüfung:
Prof. Dr. rer. nat. H.K. Kroemer

Prof. Dr. med. N. Miosge

PD Dr. med. Dr. med. dent. R. Gruber 
INHALT

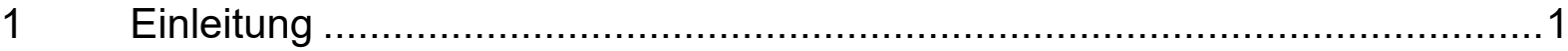

1.1 Aufbau und Funktion des Knochens .................................................. 1

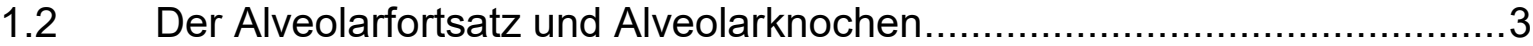

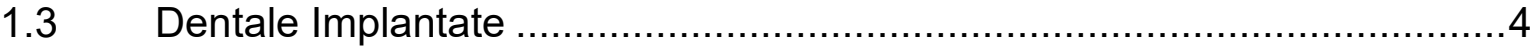

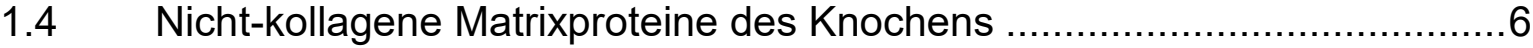

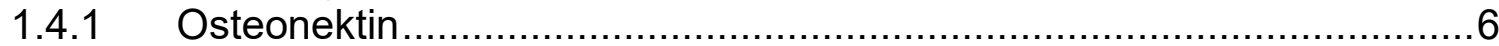

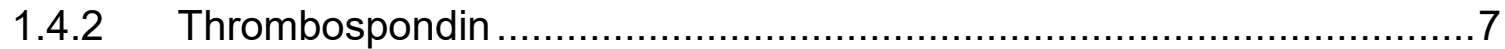

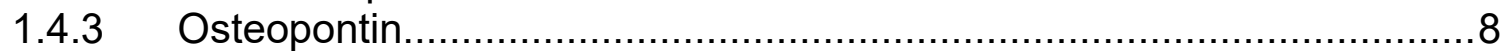

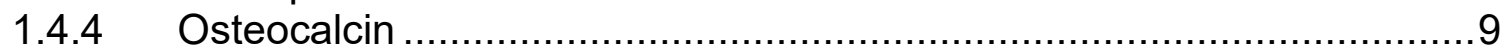

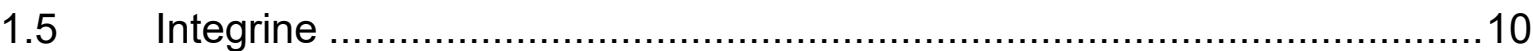

$2 \quad$ Fragestellung und Zielsetzung der Arbeit......................................... 12

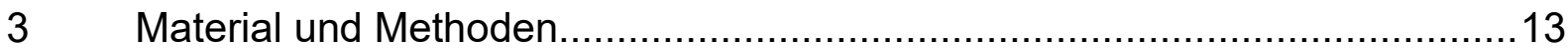

3.1 Quantitative Bestimmung der mRNA mittels real-time RT- PCR .............13

3.1.1 Gewinnung des Alveolarknochens von Mäusen ............................... 13

3.1.2 Isolierung der RNA aus dem Alveolarknochen .............................. 13

3.1.3 Umschreiben der mRNA in cDNA .......................................... 15

3.1.4 Die real-time RT-Polymerase-Kettenreaktion (PCR) ....................... 15

3.1.5 Primer Design ......................................................................... 17

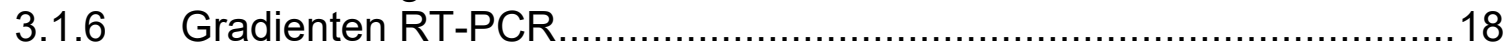

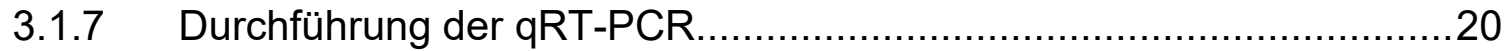

3.1.8 Effizienzkorrigierte Auswertung nach Pfaffl.................................21

3.1.9 Relative Quantifizierung ......................................................... 21

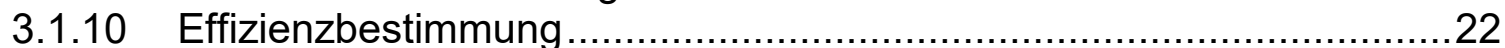

3.2 Lichtmikroskopischer Nachweis von Osteocalcin, Osteopontin und

Osteonektin mittels Immunhistochemie im Tuber maxillae und der

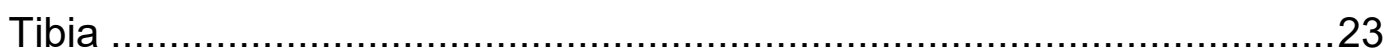

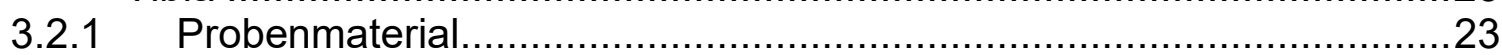

3.2.1.1 Gewinnung des Alveolarknochens......................................... 23

3.2.1.2 Herkunft des Tibiaknochens …......................................... 24

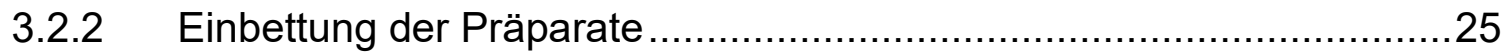

3.2.3 Anfertigung der Gewebeschnitte ............................................... 26

3.2.4 Entparaffinierung und Rehydratation .......................................... 26

3.2.5 Zur Methode der Immunhistochemie ........................................... 27

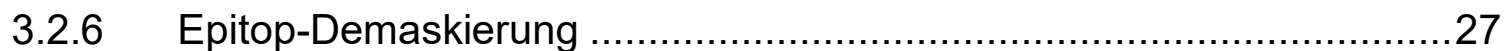

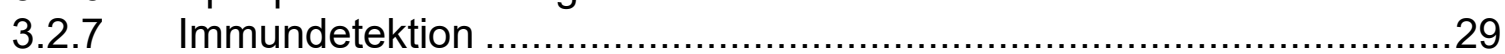

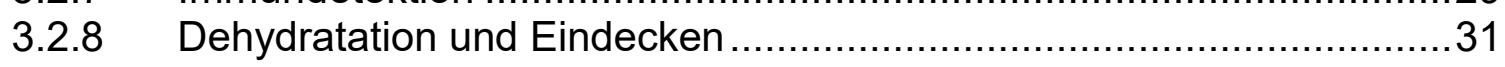


3.3 Statistische Methodik

$4 \quad$ Ergebnisse

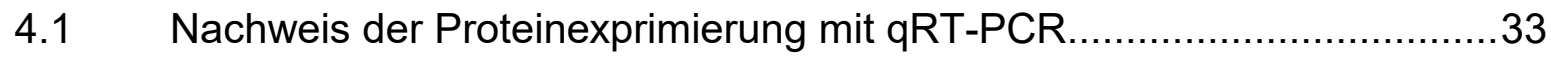

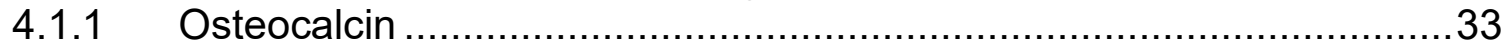

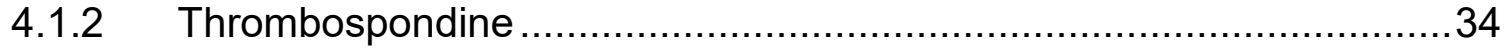

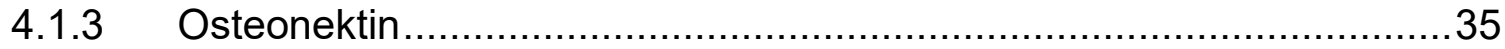

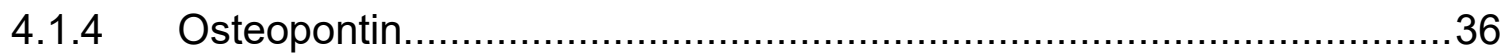

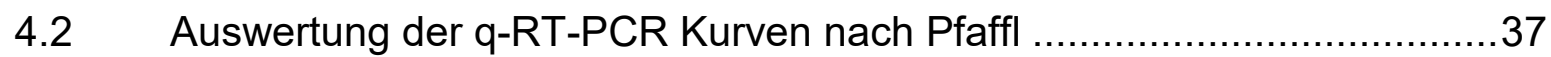

4.2.1 Housekeeping-Gen Beta-Aktin bei Probe und Referenz.....................37

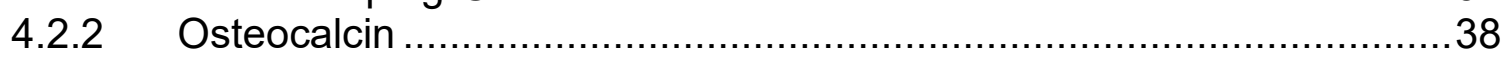

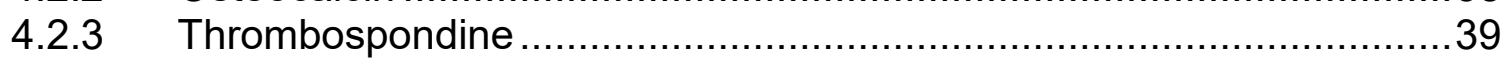

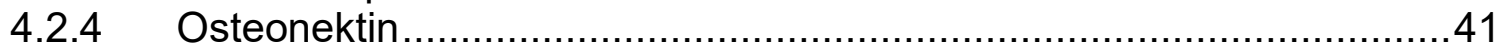

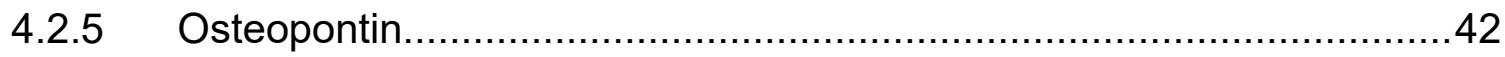

4.3 Immunohistologischer Nachweis von Osteocalcin, Osteonektin und

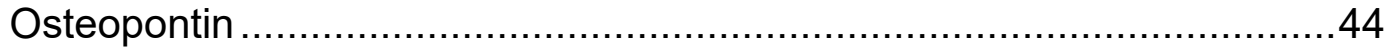

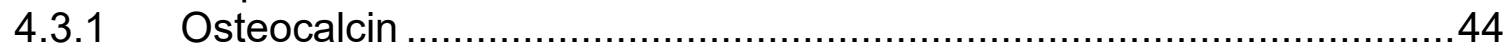

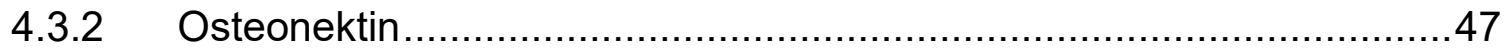

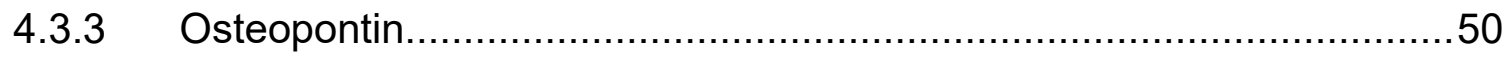

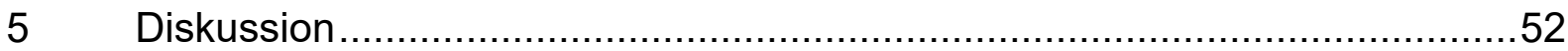

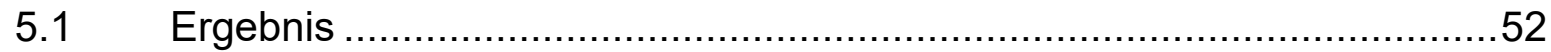

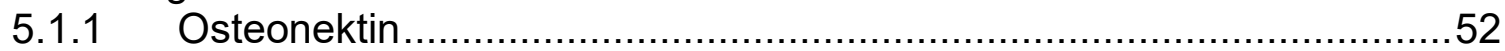

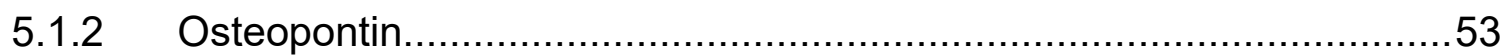

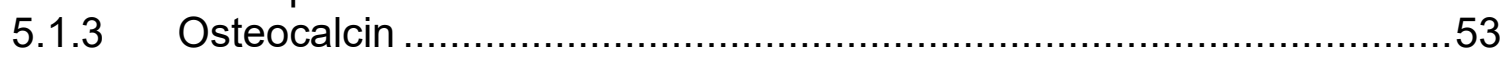

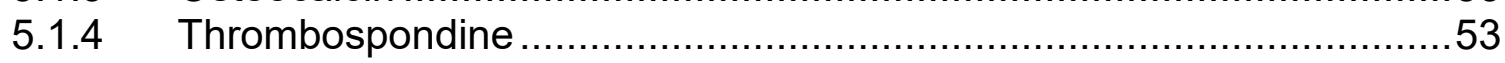

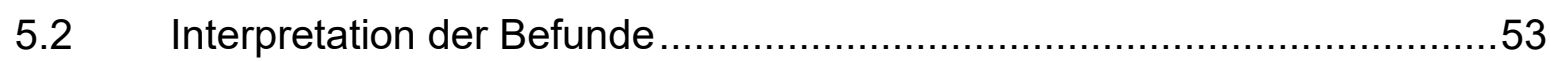

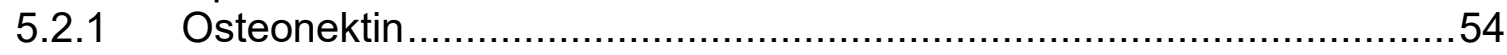

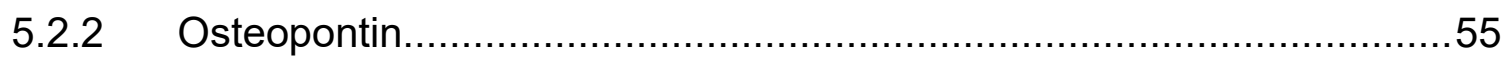

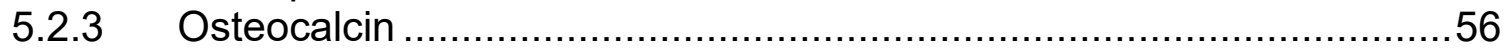

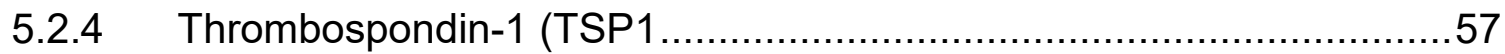

5.3 Zusammenfassende Analyse der Resultate ...................................58

5.4 Diskussion der Resultate .................................................................. 60

5.4.1 Kritische Betrachtung der Methode ..........................................60

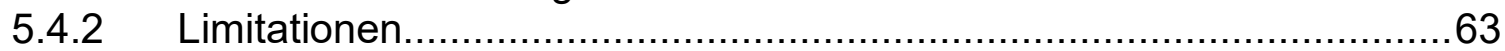

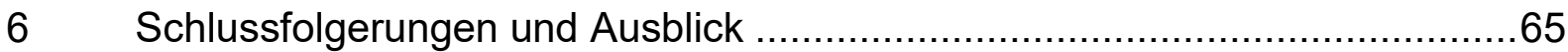

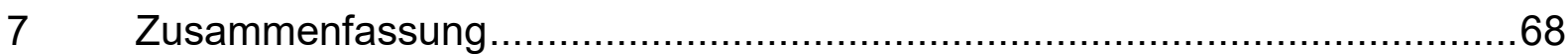

$8 \quad$ Verzeichnis der Abkürzungen ....................................................... 70 
$9 \quad$ Verzeichnis der Tabellen ...................................................................... 72

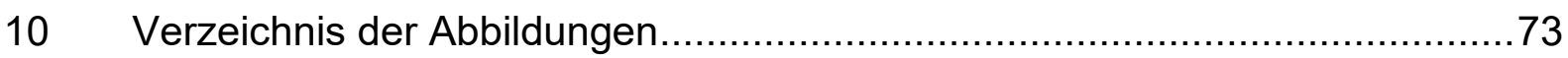

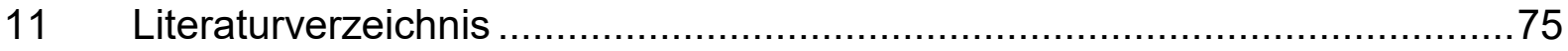




\section{Einleitung}

Die vorliegende Arbeit untersucht die These, dass das besondere Einheilungsverhalten etwa dentaler Implantate im Alveolarknochen durch das vermehrte Vorhandensein bestimmter wachstumsfördernder Proteine des Alveolarknochens begünstigt wird.

\subsection{Aufbau und Funktion des Knochens}

Der menschliche Knochen dient als Stützapparat sowie als Calcium- und Phosphatspeicher. Er besteht zu $30 \%$ aus einem organischen und zu $70 \%$ aus einem anorganischen Anteil. Dabei setzt sich der anorganische Teil hauptsächlich aus Calcium und Phosphor zusammen, welche in einem gemeinsamen Komplex, dem sogenannten Hydroxylapatit, vorliegen. Kollagen Typ I bildet mit über $90 \%$ den größten Teil der organischen Matrix des Knochens. Neben Kollagen Typ III, Typ V und Typ VI bilden nicht-kollagene Proteine wie Osteocalcin, Osteonektin, Osteopontin, Sialoprotein, Proteoglykane und Serumproteine die restlichen organischen Bestandteile.

Zelluläre Bestandteile des Knochens sind Osteoklasten, Osteozyten, Osteoblasten und endostale Belegzellen, die sogenannten bone lining cells. Vollständig differenzierte Osteoblasten bilden Kollagen Typ I und regulieren dessen Mineralisation. Osteozyten liegen eingeschlossen in der Knochenmatrix, stehen aber über ein System von Kanälen, den sogenannten Haversschen Kanälen, miteinander in Kontakt. Dieser Kontakt erfolgt über bis zu $200 \mu \mathrm{m}$ lange Zellfortsätze, die über gap junctions verbunden sind. Die Belegzellen sind auf der Knochenoberfläche zu finden, Osteoklasten hingegen können sich bewegen und sind für den Knochenabbau verantwortlich (Felsenberg 2001).

Es wird zwischen Geflecht- und Lamellenknochen unterschieden. Unter Geflechtknochen versteht man eine unreife Form des Knochengewebes. Hier liegen Kollagenfasern und Knochenmatrix in einer ungeordneten Struktur vor, woraus eine geringe Belastungsfähigkeit resultiert. Diese Art des Knochens findet sich in der Entwicklung oder während Heilungsvorgängen. Letztlich wird 
der Geflechtknochen durch Lamellenknochen ersetzt. Dies ist ein vollständig mineralisierter, strukturierter Knochen und der Hauptbestandteil von Kompakta und Spongiosa. Kompakta ist massiv und findet sich in den Randbezirken eines Knochens, wohingegen sich Spongiosa im Inneren befindet. Diese stellt sich als Gebilde aus feinen Knochenbälkchen (Trabekel) dar (Welsch 2006).

Der Knochen unterliegt einem ständigen Auf- und Abbau (Remodeling). Damit reagiert er auf verschiedene physiologische Belastungsformen, indem er entweder seine Oberfläche verändert, oder es ändert sich die Mineralisation des Gewebes. Dieser Vorgang wird durch diverse Faktoren beeinflusst, unter anderem durch die oben genannten nicht-kollagenen Proteine, welche auch bei der Frakturheilung eine Rolle spielen.

Die vorliegende Arbeit beschäftigt sich mit der Bedeutung einiger ausgewählter Proteine der extrazellulären Matrix des knöchernen Zahnfachs, dem sogenannten Alveolarknochen. Liegen bestimmte Proteine in einer auffallenden Konzentration vor, könnte diese besondere Zusammensetzung des Alveolarknochens z. B. für die Einheilung von dentalen Implantaten in den Kieferknochen bzw. direkt in das Zahnfach nach Zahnextraktion von Bedeutung sein.

In der Zahnmedizin gibt es Situationen, in denen das Knochenangebot für eine Implantation nicht ausreicht und augmentiert werden muss. Hierfür bedient man sich entweder xenogenen Materials, welches aus aufbereiteten tierischen Knochen besteht oder eines patienteneigenen Knochens (autogenes Transplantat). Entscheidet man sich für ein autogenes Transplantat, gibt es die Möglichkeit, dieses der Beckenschaufel oder ortsständigen Knochen wie dem Kieferwinkel bzw. dem Kinn zu entnehmen. Auch in diesem Fall könnte die unterschiedliche lokale Zusammensetzung der extrazellulären Matrixproteine eine Rolle spielen. 


\subsection{Der Alveolarfortsatz und Alveolarknochen}

Es wird zwischen dem Alveolarfortsatz und dem eigentlichen Alveolarknochen unterschieden. Als Alveolarknochen wird der innen liegende, das Zahnfach auskleidende Knochen bezeichnet. Der Alveolarfortsatz ist der Abschnitt des Kiefers, der den Zahn bzw. die Zähne umfasst und so das eigentliche Zahnfach bildet. Im Oberkiefer wird dieser Teil des Knochens als Processus alveolaris und im Unterkiefer als Pars alveolaris mandibulae bezeichnet. Der Alveolarknochen besteht aus kompakterem Knochen, der inn direkt umgebende Knochen ist spongiös.

Abb.1.1: Das knöcherne Zahnfach (Wolf et al. 2003, S. 17): C (kompakter Knochen= Alveolarknochen), S (Spongiöser Knochen)

Wie auf Abbildung $1 \mathrm{zu}$ sehen ist, hat der Alveolarknochen viele kleine Öffnungen, daher bezeichnet man diesen Teil auch als Lamina cribriformis. Durch diese sogenannten Volkmann- und Hartmannkanäle ziehen sich Blut- und Nervengefäße. Der Alveolarknochen kleidet die gesamte Alveole aus und bildet koronal den Alveolarknochenkamm, der in ca. 1-2 mm Abstand parallel zur Schmelz-Zementgrenze des Zahnes verläuft und auch als Limbus alveolaris bezeichnet wird. Hier geht er in die äußere Schicht der Kompakta des Kieferknochens über. 
Der Zahn ist mit seiner Alveole nicht fest verwachsen, sondern über Kollagenund Oxytalanfasern flexibel aufgehängt. Diese Fibrae dento-alveolaris (SharpeyFasern) inserieren im Wurzelzement, wandeln die Druckkräfte, die der Zahn während seiner Funktion erfährt, in Zugkräfte um und leiten sie an den Alveolarknochen weiter. Dies ist möglich, weil sie gewellt von koronal nach apikal verlaufen und durch einwirkende Kräfte gestreckt werden (Lehmann et al. 2008).

Diese Belastungsform von Knochengewebe findet sich auch in den Ansätzen von Sehnen und Bändern des Skeletts. In diesen Regionen liegt ein spezieller Typ des Geflechtknochens vor, man spricht dort, ebenso wie bei Alveolarknochen, von Bündel- oder Faserknochengewebe (Schwenzer und Ehrenfeld 2009).

Fehlt ein Zahn und somit die physiologische Belastung des Kieferknochens, bildet sich der Alveolarfortsatz schon nach kurzer Zeit zurück. Dies ist daher mit entscheidend für den Zeitpunkt einer geplanten Implantation.

\subsection{Dentale Implantate}

Dentale Implantate dienen in der Zahnmedizin dazu, verloren gegangene Zähne zu ersetzen. Dabei substituieren sie entweder einzelne Zähne oder dienen als Pfeiler, die den Halt von Zahnersatz verbessern bzw. diesen erst ermöglichen. Sie sind im Gegensatz zu anderen orthopädischen Implantaten meist aus sogenanntem Reintitan. Neuere Implantatsysteme bestehen auch aus Zirkonoxid-Keramiken, hierzu liegen jedoch keine Langzeiterfahrungen vor. Zumeist sind die Implantate schraubenförmig und werden in den Ober- bzw. Unterkiefer inseriert, das heißt, sie stehen in direktem Kontakt zum Kieferknochen. Bei neu entwickelten Implantaten ahmt der mittlere Teil die trabekuläre Form der Spongiosa nach; dies soll zum Ein- und Anwachsen des Implantats beitragen (Wigfield et al. 2003). Neben der Entwicklung unterschiedlicher Formen und Materialien für Implantate gibt es auch Bestrebungen, das sogenannte Mikrodesign dieser zu verbessern, indem die Implantate mit 
Bestandteilen der extrazellulären Matrix oder Wachstumsfaktoren beschichtet werden (Eckelt et al. 2007).

Bei der Einheilung von Implantaten in den Knochen werden zwei verschiedene Formen unterschieden: die fibroossäre Einheilung und die Osseointegration.

Bei der fibroossären Einheilung liegt zwischen dem Implantat und dem eigentlichen Knochen eine aus Bindegewebe bestehende Zone. Diese Bindegewebszone gilt als klinischer Misserfolg, da dieser Verbund zwischen Implantat und Knochen anfällig für bakterielle Kontaminationen ist und die Prognose daher als schlecht bezeichnet wird. Die Osseointegration ist definiert als die direkte, strukturelle und funktionelle Anlagerung von geordnetem, lebendem Knochen an die Oberfläche eines Last tragenden Implantats ohne Nachweis von Weichgewebe auf lichtmikroskopischem Niveau und Erhalt dieser Verbindung unter Funktion (Brånemark et al. 1977).
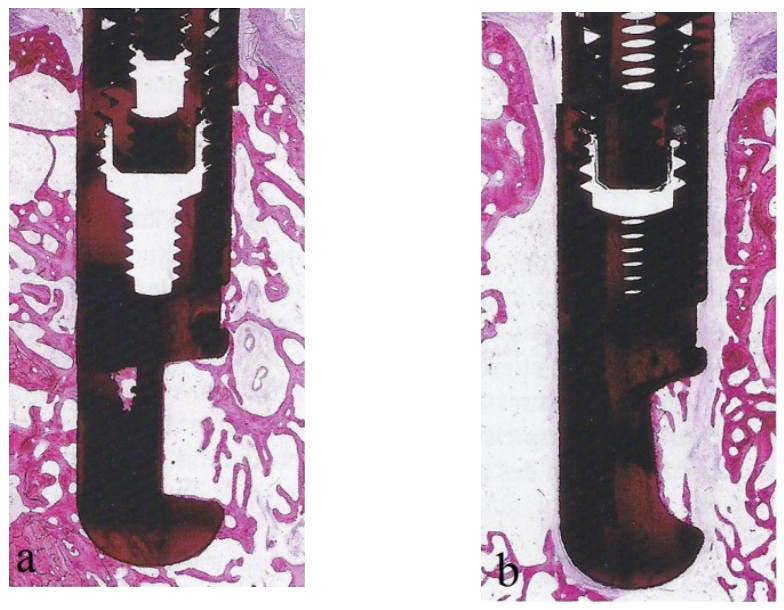

Abb.1.2: Osseointegration und fibroossäre Einheilung (Schwenzer und Ehrenfeld 2009, S. 232): a Osseointegration; b fibroossäre Einheilung

Neben dem korrekten chirurgischen Vorgehen ist für die erfolgreiche Osseointegration des Implantats die Qualität des umgebenden Knochens entscheidend. Unter zellulärer Betrachtung weist ein qualitativ guter Knochen ein hohes Regenerationspotenzial auf, das heißt, er ist in der Lage, das Präparationstrauma schnell zu heilen (Schwenzer und Ehrenfeld 2009). Proteine der extra- 
zellulären Matrix beeinflussen diese Qualität mit, da sie direkte Auswirkungen auf die Osseointegration haben (Stanford und Keller 1991).

Nach der Implantation findet zunächst die Wundheilung mit Bildung von Granulationsgewebe und einer Fremdkörperreaktion in der Region um das Implantat statt. Nach 14 Tagen beginnt sich ein Geflechtknochen in Form eines Kallus zu bilden mit parallel stattfindender Resorption. Der Geflechtknochen nimmt durch Osteoblastenfunktion zunehmend eine lamelläre Gestalt an, was zu einer Festigung des Implantats führt. Letztlich bildet sich ein neuer Knochen, der bis zu einem Jahr nach Implantation weiter sklerosiert (Schwenzer und Ehrenfeld 2009).

\subsection{Nicht-kollagene Matrixproteine des Knochens}

\subsubsection{Osteonektin}

SPARC (secreted protein acid and rich in cysteine), welches auch als Osteonektin (ON) bezeichnet wird, ist ein $32 \mathrm{kDa}$ großes Protein, das vor allem in Geweben mit hohen Umbauraten - wie dem Knochen - oder bei Verletzungen vorkommt (Termine et al. 1981). Findet sich SPARC in der Basalmembran, wird es auch als BM40 bezeichnet. Im Knochen wird es von Osteoblasten synthetisiert und hat hier die Möglichkeit, an weitere Komponenten der extrazellulären Matrix wie Hydroxylapatit, Thrombospondin, Kollagen und Calcium sowie an Zellen zu binden (Lane und Sage 1994). SPARC hat Auswirkungen auf die Kollagensynthese und auf die Anordnung von Kollagen I in der extrazellulären Matrix. Wahrscheinlich kann SPARC über die Bindung an Proteine der Zelloberfläche die Konformität und die Proliferation dieser beeinflussen (Sage und Bornstein 1991). Die Tatsache, das SPARC die Differenzierung von Osteoblasten (Delany et al. 2003) sowie die Expression von Matrixmetalloproteinasen fördert und Auswirkungen auf die Effektivität von Wachstumsfaktoren hat, lässt darauf schließen, dass dieses Matrixprotein entscheidend die Zellinteraktion mit der extrazellulären Matrix in der Entwicklung und während der Verletzungsreaktion beeinflusst (Bradshaw und Sage 2001). 
Im Knochen findet man SPARC in der perizellurären Matrix von Osteoblasten und Osteozyten (Alford und Hankenson 2006).

\subsubsection{Thrombospondin}

Thrombospondine (TSP) sind Glykoproteine, die Einfluss auf die Angiogenese und auf den Kontakt von Zellen zur extrazellulären Matrix haben. Es gibt insgesamt fünf Thrombospondine, die in zwei Gruppen unterteilt werden: TSP-1 und 2 sowie TSP-3, -4 und -5 . Die beiden Thrombospondine TSP-1 und -2 setzen sich aus drei Ketten mit einem jeweiligen Molekulargewicht von 145 kDa zusammen, wohingegen die TSP-3 und -5 Pentamere aus Untereinheiten mit jeweils 105 kDa bestehen (Bornstein und Sage 1994). Im Knochen werden sie von mesenchymalen Zellen und von Chondrozyten des sich bildenden Knorpels exprimiert (Mackie und Murphy 1998).

TSP-1 und TSP-2 können an verschiedene Proteine der extrazellulären Matrix wie Fibrinogen, Kollagen, Heparansulfat, Proteoglykane, Fibronectin und Laminin binden (Alford und Hankenson 2006); allerdings sind sie in der extrazellulären Matrix nicht für die strukturelle Integrität zuständig. Sie üben Einfluss auf Zellen aus und können so indirekt auf Vorgänge im Knochen einwirken (Bornstein 2001). Diese Eigenschaft besitzen nicht nur TSP-1 und TSP-2, sondern auch Proteine wie SPARC, Tenascin C und Osteopontin, sodass bei dieser Gruppe auch von matricellular Proteinen gesprochen wird (Bornstein 1995). TSP-1 kann über das Integrin avß3 (Lawler und Hynes 1989) und den Cluster of Differentiation 36 (CD36) an Zellen binden (Asch et al. 1991). So fördert beispielsweise die Bindung von TSP-1 an Osteoklasten über den CD36-Rezeptor die Knochenresorption (Carron et al. 2000). Durch die Möglichkeit der Inhibition der Angiogenese könnten Thrombospondine die Vaskularisation während der Knochenbildung regulieren (Armstrong und Bornstein 2003; Streit et al. 1999). Ebenso verhindert TSP-1 die Mineralisation des Knochens (Ueno et al. 2006). Weiterhin scheint TSP-1 aufgrund seiner Beeinflussung der entzündlichen Reaktion im Zuge der Wundheilung eine wichtige Rolle während dieser zu spielen (Bornstein et al. 2004). 


\subsubsection{Osteopontin}

Osteopontin (OPN) ist ein stark phosphoryliertes Sialoprotein, das hauptsächlich in der mineralisierten extrazellulären Matrix von Kochen und Zähnen vorkommt (Giachelli und Streitz 2000). Seine Größe variiert zwischen 44 kDa und 75 kDa (Sodek et al. 2000). Dieses Matrixprotein wurde ursprünglich Bone Sialoprotein I (BSP I) genannt und zusammen mit dem BSP II entdeckt (Franzén und Heinegård 1985). Der Name Osteopontin beruht auf seiner Fähigkeit, durch eine Polyasparaginsäure- und RGD-Sequenz den Kontakt von Zellen zu Hydroxylapatit zu ermöglichen (Oldberg et al. 1986). Die RGD-Sequenz ist die Aminosäuresequenz der drei Aminosäuren Arginin, Glycin und Asparaginsäure, ArgGly-Asp. Die Bindung an die Zellen erfolgt dabei über sogenannte Integrine, in diesem Fall über das Integrin $\alpha \vee \beta 3$, welches sich auf der Zelloberfläche befindet (Ross et al. 1993). Neben der Möglichkeit, über Integrine an Zellen zu binden, kann OPN dies auch über den CD44-Rezeptor (Weber et al. 1996). OPN wird während der Knochenentwicklung von Osteozyten und Osteoblasten in die extrazelluläre Matrix sezerniert (Cowles et al. 1998), wo es in seiner phosphorylierten Form die Mineralisation inhibiert (Goldberg und Hunter 1995; Giachelli und Streitz 2000). Während der enchondralen Ossifikation im Zuge einer Frakturheilung wird OPN von vollständig differenzierten Chondrozyten, Osteoblasten und Osteoklasten exprimiert. Die Transkription von OPN wird durch Vitamin D3 vermehrt (Prince und Buter 1987) und während der Knochenresorption vermittelt OPN die Adhäsion der Osteoklasten an den Knochen (Ross et al. 1993).

Im Zuge des Remodelings spielt OPN eine Rolle bei der Verbindung des alten mit dem neuen Knochen (McKee und Nanci 1995). Die durch das Parathormon indirekt induzierte Knochenresorption über den Receptor-activator of nuclear factor $K B$ ligand (RANKL) kann ohne OPN nicht stattfinden (Ihara et al. 2001). 


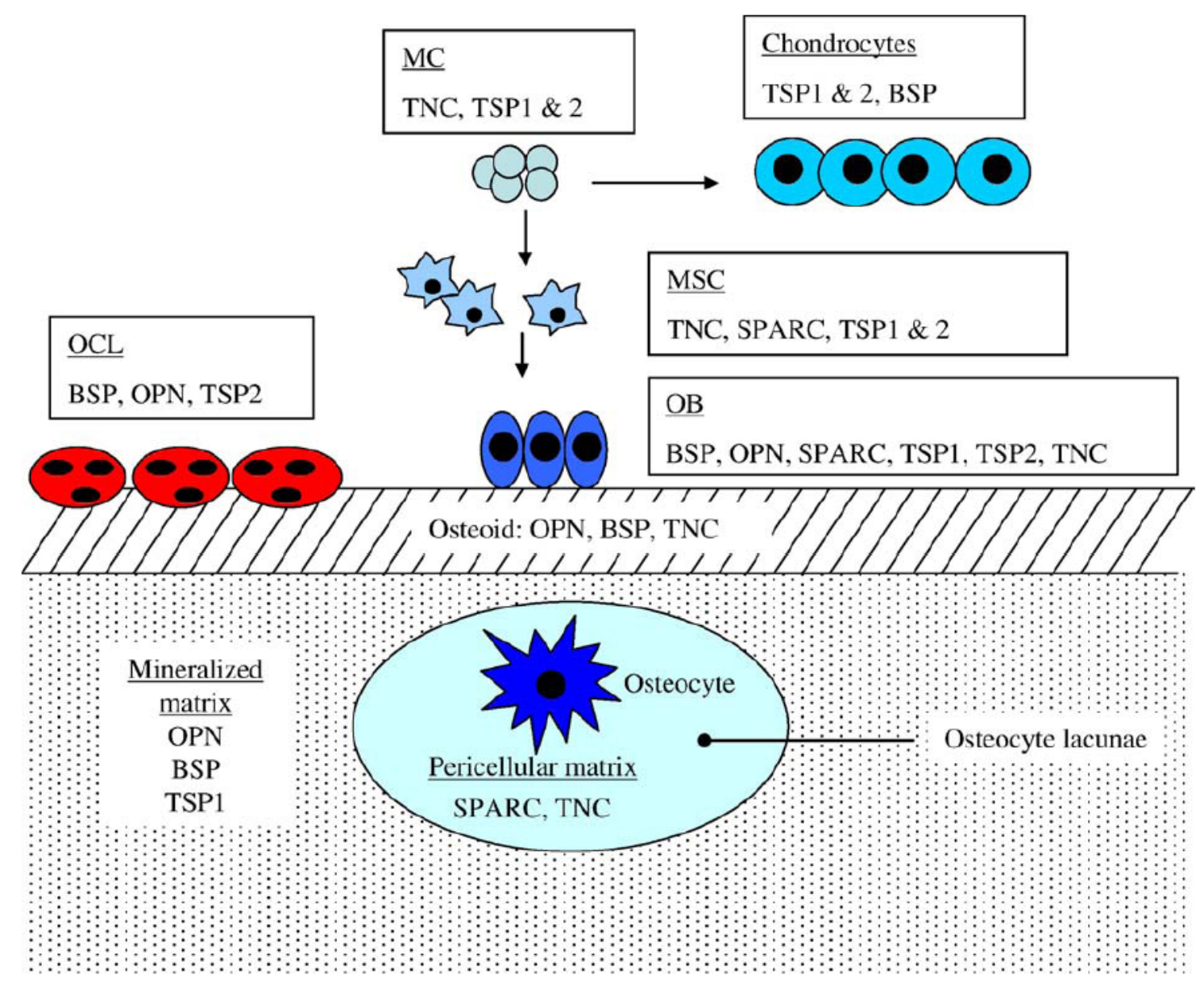

Abb.1.3: Expression von Matrixproteinen durch Knochenbelegzellen (Alford und Hankenson 2006, S. 753), Expression der Matrixproteingene stehen in den Kästen neben den jeweiligen Zellen. Die Zusammensetzung von neu gebildetem Osteoid und mineralisierter Matrix ist ebenso dargestellt. Abkürzungen: MC (Mesenchymales Kondensat); MSC (Knochenmark Stammzellen); OB (Osteoblast); OC (Osteozyte); OCL (Osteoklast); TNC (Tenascin C); OPN (Osteopontin); TSP (Thrombospondin)

\subsubsection{Osteocalcin}

Osteocalcin $(\mathrm{OC})$ war das erste nicht-kollagene Matrixprotein des Knochens, welches 1975 charakterisiert werden konnte. Es ist auch unter dem Namen bone gamma-carboxyglutamic acid-containing protein (BLAP; BGP) bekannt. Osteocalcin wird im Knochen von Osteoblasten und im Dentin des Zahnes von Odontoblasten gebildet und ist ein 5,8 kDa großes Protein, welches posttranskriptional durch Vitamin K-abhängige Enzyme modifiziert wird, sodass es unter anderem an verschiedene Faktoren der Blutgerinnungskaskade binden kann. 
Hierbei werden in einer Vitamin K-abhängigen Reaktion zwei Glutaminsäuren in drei der namensgebenden Gamma-Carboxyglutaminsäuren umgewandelt, die es dem Osteocalcin ermöglichen, an Calcium zu binden (Hauschka et al. 1989; Sodek und McKee 2000). Wird diese Modifikation mit dem Vitamin KAntagonisten Warfarin blockiert, sinkt die Osteocalcin-Konzentration im Knochen und dieser wird hypermineralisiert (Price und Williamson 1981). Da der gleiche Effekt bei Mäusen beobachtet wurde, deren Bglap-Gen ausgeschaltet war (Ducy et al. 1996), lässt dies den Schluss zu, dass Osteocalcin die Mineralisation der Knochenmatrix reguliert (Sodek und McKee 2000).

Aktuelle Forschungen zeigen, dass Osteocalcin eine blutzuckersenkende Wirkung hat, indem es die Insulinsekretion fördert (Ferron et al. 2008). Sogar eine fruchtbarkeitsfördernde Wirkung konnte an männlichen Mäusen gezeigt werden (Oury et al. 2011).

\subsection{Integrine}

Integrine sind Rezeptoren, die die Bindung von Zellen an Proteine der extrazellulären Matrix vermitteln (Hynes 2002). Im Knochen besitzen z. B. Osteoprogenitorzellen, Osteoblasten und Osteoklasten diese Transmembranproteine (Cohen et al. 2004). Integrine bestehen aus einer $\alpha$ - und $\beta$-Untereinheit, sie erkennen spezifische Proteine bzw. bestimmte Abschnitte dieser und können daran binden. Zu diesen Bereichen der Proteine gehört die oben beschriebene RGD-Sequenz (Garcia 2005).

Bindet ein Protein an ein Integrin, verbindet sich der zytoplasmatische Teil dieses Rezeptors mit dem Zytoskelett und mit Transduktionsmolekülen der Zelle. Dadurch werden verschiedene Signalkaskaden ausgelöst, wie z. B. FAK, Proteinkinase C, Rac, Rho und MAPK (Shekaran und Garcia 2010). Über diesen Weg können Zellzyklus, -wachstum und -differenzierung oder das Einwandern von Zellen geregelt werden und somit auch die Entstehung, Aufrechterhaltung und Heilung von Gewebe (Giancotti und Ruoslathi 1999; Chen et al. 1997; Danen und Sonnenberg 2003). Darüber hinaus sind Integrine für die 
biologische Reaktion von Gewebe auf ein Implantat von Bedeutung (Anderson 2001).

Das Integrin $\alpha v \beta 3$ wird auch als Vitronectinrezeptor bezeichnet (Felding-Habermann und Cheresh 1993). Der Name suggeriert, dass das Integrin primär Vitronectin bindet, es kann aber über die RGD-Sequenz auch eine Vielzahl anderer Proteine binden. Man findet es nur auf bestimmten Zelltypen wie einigen Tumorzellen, Endothelzellen der Blutgefäße und Osteoklasten. Das Integrin avß3 gehört zu den meist exprimierten Integrinen auf der Oberfläche von Osteoklasten. Die Adhäsion von Osteoklasten an die Knochenoberfläche kann durch Proteine mit RGD-Sequenz geblockt und die Knochenresorption in vitro inhibiert werden. Auch mit av $\beta 3$ Antikörpern konnte eine solche Adhäsion blockiert werden (Rodan und Rodan 1997). 


\section{Fragestellung und Zielsetzung der Arbeit}

Ziel der vorgelegten Arbeit ist die Bestimmung der Quantität der mRNA ausgewählter Proteine der extrazellulären Matrix im Alveolarknochen mithilfe der real-time RT-PCR. Dabei wurden die Proteine unter dem Gesichtspunkt des Remodelings und dem möglichen Einfluss auf die Einheilung dentaler Implantate und die Knochenaugmentation ausgewählt.

Die besondere Zusammensetzung des Alveolarknochens soll auf diesen Aspekt hin untersucht werden.

Als qualitativer Nachweis dient eine immunhistologische Untersuchung des humanen Alveolarknochens und der Tibia. 


\section{Material und Methoden}

\subsection{Quantitative Bestimmung der mRNA mittels real-time RT- PCR}

\subsubsection{Gewinnung des Alveolarknochens von Mäusen}

Da humaner Alveolarknochen für die Gewinnung von RNA nicht in ausreichender Menge zur Verfügung stand, wurde dieser von Mäusen der Linie C57/BL6 gewonnen. Die Studie wurde durch die Tierschutzkommission der Medizinischen Fakultät der Georg August Universität Göttingen genehmigt. Es wurden je fünf männliche und fünf weibliche Tiere zur Probengewinnung benötigt. Die Tiere wurden mittels zervikaler Dislokation im Alter von 6 Monaten getötet. Der Kopf wurde vom Rumpf abgetrennt und das Cranium von Weichgewebe befreit. Nach vorsichtiger Extraktion der Seitenzähne wurde unter lichtmikroskopischer Kontrolle mithilfe einer Splitterpinzette der so dargestellte Alveolarfortsatz mit dem Alveolarknochen aus dem Kiefer herausgebrochen. Um eine ausreichende Gewebemenge zu erreichen, wurden die Proben aller Tiere in einem Pool zusammengefasst. Zur Gewinnung der Referenz-mRNA wurde der Unterkieferwinkelknochen gewählt, welcher ebenfalls präpariert wurde.

\subsubsection{Isolierung der RNA aus dem Alveolarknochen}

Um die RNA aus den in den Proben enthaltenen Zellen gewinnen zu können, darf deren Integrität nicht intakt sein. Zum Aufschluss der Zellen wurde der Probenpool in einen Porzellanmörser gegeben und anschließend mit flüssigem Stickstoff übergossen. Dieser hat eine Temperatur von $-196{ }^{\circ} \mathrm{C}$, sodass die Knochenfragmente schockgefroren wurden und mit einem Stößel leicht zu zerkleinern waren. In diesem Prozess wurden die Membranen der Zellen zerstört, sodass die enthaltene RNA freigesetzt wurde.

Das so entstandene Pulver wurde in $1 \mathrm{ml} \mathrm{TriFast}^{\mathrm{TM}}$ (Fa. PEQLAB, Erlangen) gelöst. Diese Lösung enthält Guanidinisothiocyanat und Phenol. Das Guanidinisothiocyanat hat die Eigenschaft, Zellen zu lysieren und vorhandene, die 
RNA abbauende Enzyme, sogenannte RNasen, zu inhibieren. Nach Zentrifugation mit $14.000 \mathrm{~min}^{-1}$ wurde die obere Phase abpipettiert. Das entnommene Volumen wurde 1:1 mit einer Chloroform-Isoamylalkohol-Mischung vermischt, für 2 Minuten bei Raumtemperatur stehen gelassen und wieder mit $14.000 \mathrm{~min}^{-1}$ zentrifugiert. Die weitere RNA-Extraktion wurde mit dem RNeasy mini Kit (Fa. Qiagen, Hilden) durchgeführt, welches RNeasy Mini-Säulen, RPE-, RW1-, RLTPuffer, QIA Shredder und RNase freies Wasser enthält.

Je 100 $\mu \mathrm{l}$ der wässrigen Phase wurden $350 \mu \mathrm{l}$ RLT-Puffer und 3,5 $\mu \mathrm{l} \beta$-Mercaptoethanol (Fa. Sigma-Aldrich, Steinheim) hinzugefügt. Das $\beta$-Mercaptoethanol dient dabei der Spaltung von Disulfidbrücken zur weiteren Denaturierung der enthaltenen Proteine. Nach sorgfältiger Durchmischung wurden $350 \mu$ absolutes Ethanol hinzugefügt und alles gemischt. Diese Suspension wurde auf eine RNeasy Mini-Säule pipettiert und zentrifugiert, der Durchfluss entsorgt.

Die Mini-Säule enthält eine Silicat-Membran, die die RNA gebunden hat. Die nun in der Säule enthaltene RNA musste anschließend gereinigt werden. Hierzu wurden $700 \mu \mathrm{l}$ RW1-Puffer auf die Membran pipettiert, zentrifugiert und der Durchfluss wurde verworfen. Das Gleiche erfolgte mit $500 \mu \mathrm{l}$ RPE-Puffer.

Nach dieser Reinigung wurde die Säule in einem neuen Sammelröhrchen mit $14.000 \mathrm{~min}^{-1}$ zentrifugiert, wodurch letzte Reste der Waschpuffer aus der Säule entfernt wurden. Anschließend wurde die Säule in ein 1,5 ml Eppendorf Reaktionsgefäß gesetzt, mit $50 \mathrm{ml}$ RNase-freiem Wasser beschickt und für zehn Minuten bei Raumtemperatur inkubiert. Durch die anschließende Zentrifugation mit $14.000 \mathrm{~min}^{-1}$ wurde die RNA aus der Membran heraus gewaschen und befand sich nun im Durchfluss. Zur spektroskopischen Konzentrationsbestimmung der entstandenen Lösung wurden $2 \mu$ dieser in ein Biophotometer (Fa. Eppendorf, Hamburg) gegeben. Dieses misst die Absorption der Probe bei 260 und $280 \mathrm{~nm}$ Wellenlänge, welche dem Absorptionsmaximum Purin- und Pyrimidinbasen der RNA entspricht. 


\subsubsection{Umschreiben der mRNA in cDNA}

Als Probe für eine RT-PCR wird cDNA benötigt. Daher musste die gewonnene RNA in solche umgeschrieben werden. Hierzu wurde das QuantiTect Reverse Transcription Kit (Fa. Quiagen, Hilden) benutzt. Angestrebt wird ein Endvolumen von $200 \mu \mathrm{l}$ mit einer Konzentration von 1ng cDNA/ $\mu \mathrm{l}$. Geht man davon aus, dass der Prozess des Umschreibens im Verhältnis 1:1 abläuft, so lässt sich mit der vorher durchgeführten Konzentrationsbestimmung der extrahierten RNA die hiervon benötigte Menge berechnen.

Das so bestimmte Volumen der RNA-Lösung wurde mit $2 \mu \mathrm{l}$ gDNA Wipeout Buffer vermischt und mit RNasen-freiem Wasser auf insgesamt $14 \mu$ laufgefüllt. Anschließend erfolgte bei $42{ }^{\circ} \mathrm{C}$ eine 2-minütige Inkubation. Dieser Schritt soll die Probe von verunreinigender, genomischer DNA reinigen. Nachfolgend wurde zu der RNA ein Mix aus Reverser Transkriptase (RT), RT Puffer und RT Primer zugegeben und für 15 min bei $42{ }^{\circ} \mathrm{C}$ inkubiert. In dieser Zeit hat die RT die RNA in cDNA umgeschrieben. Um diese Reaktion zu stoppen, erfolgte eine 3-minInkubation bei $95{ }^{\circ} \mathrm{C}$. Bis zur Verwendung der cDNA wurde diese bei $-20{ }^{\circ} \mathrm{C}$ gelagert.

\subsubsection{Die real-time RT-Polymerase-Kettenreaktion (PCR)}

Mithilfe der PCR ist es möglich, DNA in vitro zu vervielfältigen. Dabei bedient man sich des Enzyms Reverse Transkriptase, daher die Abkürzung RT-PCR. Durch die reine Vervielfältigung der Nukleinsäuren allein ist jedoch noch keine quantitative Aussage über diese möglich. Dies wird erst möglich, wenn man einen Farbstoff (SYBR-Green) hinzugibt, der fluoresziert, wenn er in doppelsträngige DNA interkaliert. Diese Fluoreszenz kann dann in Echtzeit (real-time) gemessen werden und ist proportional zu der neu entstandenen DNA, sodass man eine quantitative Aussage treffen kann (qRT-PCR). Der Vorteil dieser molekularbiologischen Methode ist, dass schon geringste Mengen an Probenmaterial genügen, um z. B. Veränderungen der Genexpression zu messen. 
Als Polymerase, die die DNA vervielfältigt, kam eine Taq-Polymerase zum Einsatz. Dieses Enzym kommt im Bakterium Thermus aquaticus vor, welches in Geysiren bei ca. $70{ }^{\circ} \mathrm{C}$ lebt. Es ist hitzestabil und denaturiert während der PCR nicht.

Ein Vervielfältigungszyklus läuft dabei in folgenden Schritten ab:

1. Denaturierung: Im ersten Schritt wird die eingebrachte, doppelsträngige cDNA bei $95{ }^{\circ} \mathrm{C}$ denaturiert, d. h., die Wasserstoffbrückenbindungen zwischen den einzelnen Basenpaaren werden gelöst. Ebenso werden die Stapelwechselwirkungen, sogenannte stacking interactions, aufgehoben. Diese sind für die Stabilität der Doppelhelix verantwortlich und abhängig vom Guanin- und Cytosin-Anteil. Dieser Schritt ist nötig, da der Primer an einen freien DNAEinzelstrang binden muss.

2. Anlagerungsphase: Diese Bindung des Primers erfolgt im zweiten Abschnitt. Dabei wird die Temperatur auf jene herabgekühlt, bei der sich der Primer am besten an die DNA anlagert.

3. Elongationsphase: Ist dies geschehen, erfolgt wiederum eine Temperaturerhöhung. Die Gradzahl ist dabei vom Temperaturoptimum der verwendeten Polymerase abhängig. Sie wird laut Herstellerangaben gewählt, sodass das Enzym bestmöglich arbeitet.

Die Synthese der DNA wird anschließend durch die folgende Temperaturerhöhung zum Aufbruch des neuen DNA-Doppelstrangs beendet.

Diese Schritte wiederholt man bis zu 45 Mal; in jedem Zyklus verdoppelt sich dabei theoretisch die gesamte DNA.

Durch den Einsatz des Fluoreszenzfarbstoffes SYBR-Green kann man diese Verdoppelung registrieren. Der Farbstoff lagert sich in die neu synthetisierte doppelsträngige DNA ein, woraufhin dieser seine Fluoreszenz steigert. Diese Zunahme wird gemessen.

Der Zyklus, in dem die Fluoreszenz des Farbstoffs erstmals die Hintergrundfluoreszenz bzw. einen festgelegten Schwellenwert übersteigt, gibt den ct-Wert 
an (= threshold cycle). Da sich eingebrachte DNA und Fluoreszenz proportional zueinander verhalten, lässt dies Rückschlüsse auf den DNA-Gehalt zu. Das heißt: Je früher sich die DNA so oft vervielfältigt hat, dass ein Fluoreszenzwert gemessen werden kann, der den Schwellenwert übersteigt, desto mehr DNA war enthalten.

\subsubsection{Primer Design}

Die Polymerase braucht ein freies 3' OH-Ende, um mit der DNA-Replikation zu starten. Dieses bietet der jeweils eingesetzte Primer, ein Oligonukleotid, das ca. 20 Basen lang ist. Die Primersequenz ist dabei so gewählt, dass sie sich an den Teil der DNA anlagert, der das zu untersuchende Protein codiert.

Um die Basenfolge des Primers für die gesuchten Proteine zu generieren, wurde die Software Primer3 benutzt. Es wurde darauf geachtet, dass die Primer eine Länge von 18-22 Basen haben und der Guanin- und Cytosin-Anteil bei ca. 50 \% liegt. Die so gewonnenen Primersequenzen wurden mit der Datenbank von NCBI Blast (Nucleotide-Nucleotide Blast (blastn), http://www.ncbi.nlm.nih.gov) abgeglichen, um eine evtl. Anlagerung an Gene auszuschließen, deren Basenfolge denen der Primer glich.

Die so überprüfte Nucleotidsequenz wurde an die Operon Biotechnologie $\mathrm{GmbH}$ (Operon Biotechnologie $\mathrm{GmbH}$, Köln, Deutschland) übermittelt. Diese synthetisierten die Primer und lieferten sie in lypholisierter Form. Nach der Resuspension mit der vom Hersteller angegebenen Menge nukleasefreien Wassers wurde eine Probe der Primer an die Sequence Laboratories Göttingen $\mathrm{GmbH}$ geschickt, um die richtige Sequenz noch einmal zu überprüfen. Es wurden folgende Primer eingesetzt: 


\begin{tabular}{|c|c|c|}
\hline \multirow{2}{*}{\begin{tabular}{|l} 
Protein \\
(Gen-Name)
\end{tabular}} & Forward (3' - 5') & \multirow{2}{*}{$\begin{array}{l}\text { Annealing Temperatur } \\
\left({ }^{\circ} \mathrm{C}\right)\end{array}$} \\
\hline & Reverse (5' - 3') & \\
\hline \multirow{3}{*}{$\begin{array}{l}\text { Knochen } \\
\text { Sialoprotein } \\
\text { (lbsp) }\end{array}$} & ccatcgaagaatcaaagca & \multirow[t]{3}{*}{55,5} \\
\hline & & \\
\hline & agtagcgtggccggtactta & \\
\hline \multirow{2}{*}{$\begin{array}{l}\text { Osteonektin } \\
\text { (Sparc) }\end{array}$} & aatttgaggacggtgcagag & \multirow[t]{2}{*}{62,5} \\
\hline & aagtggcaggaagagtcgaa & \\
\hline \multirow{2}{*}{$\begin{array}{l}\text { Osteopontin } \\
(\mathrm{Spp} 1)\end{array}$} & tgcacccagatcctatagc & \multirow[t]{2}{*}{61,5} \\
\hline & ctccatcgtcatcatcatc & \\
\hline \multirow{2}{*}{$\begin{array}{l}\text { Osteocalcin } \\
\text { (Bglap) }\end{array}$} & aagcaggagggcaataagg & \multirow[t]{2}{*}{62,5} \\
\hline & gctgccagagtttggcttt & \\
\hline \multirow{2}{*}{$\begin{array}{l}\text { Thrombospondin-1 } \\
\text { (Thbs1) }\end{array}$} & gcgatgatgacgatgacaa & \multirow[t]{2}{*}{63} \\
\hline & tctgtgtctgcttggtcag & \\
\hline \multirow{2}{*}{$\begin{array}{l}\text { Integrin } \beta 3 \\
\text { (Itgb3) }\end{array}$} & atatcctggtggtcctgctg & \multirow[t]{2}{*}{63} \\
\hline & cccggtaggtgatattggtg & \\
\hline \multirow{2}{*}{$\begin{array}{l}\text { Integrin } \alpha \mathbf{v} \\
\text { (Itgav) }\end{array}$} & gggtgatcatcttggcag & \multirow[t]{2}{*}{58} \\
\hline & gaacttggagcggacaga & \\
\hline \multirow{2}{*}{$\begin{array}{l}\text { Beta-Aktin } \\
\text { (Actb) }\end{array}$} & gtccctcaccctcccaaaag & \multirow[t]{2}{*}{62,5} \\
\hline & gctgcctcaacacctcaaccc & \\
\hline
\end{tabular}

Tab.3.1: Primer für die real-time RT-PCR

\subsubsection{Gradienten RT-PCR}

Jeder Primer hat eine andere ideale Annealing-Temperatur, bei der er sich am effektivsten an die DNA anlagert. Um diese herauszufinden, wurde eine Gradienten-PCR durchgeführt. Bei dieser PCR werden acht verschiedene Annealing-Temperaturen getestet. Um die optimale Annealing-Temperatur zu 
bestimmen, erfolgte eine Schmelzkurvenanalyse der jeweiligen Produkte. Hierbei wird die Temperatur alle 8 Sekunden von $50{ }^{\circ} \mathrm{C}$ auf $95^{\circ} \mathrm{C}$ in $0,3{ }^{\circ} \mathrm{C}$-Schritten erhöht. Während des Schmelzvorganges wird wieder die Fluoreszenz gemessen. Bei einer bestimmten Temperatur denaturiert die doppelsträngige DNA wieder in Einzelstränge und das gebundene SYBR-Green ist ungebunden. Dieser Fluoreszenzabfall wird registriert.

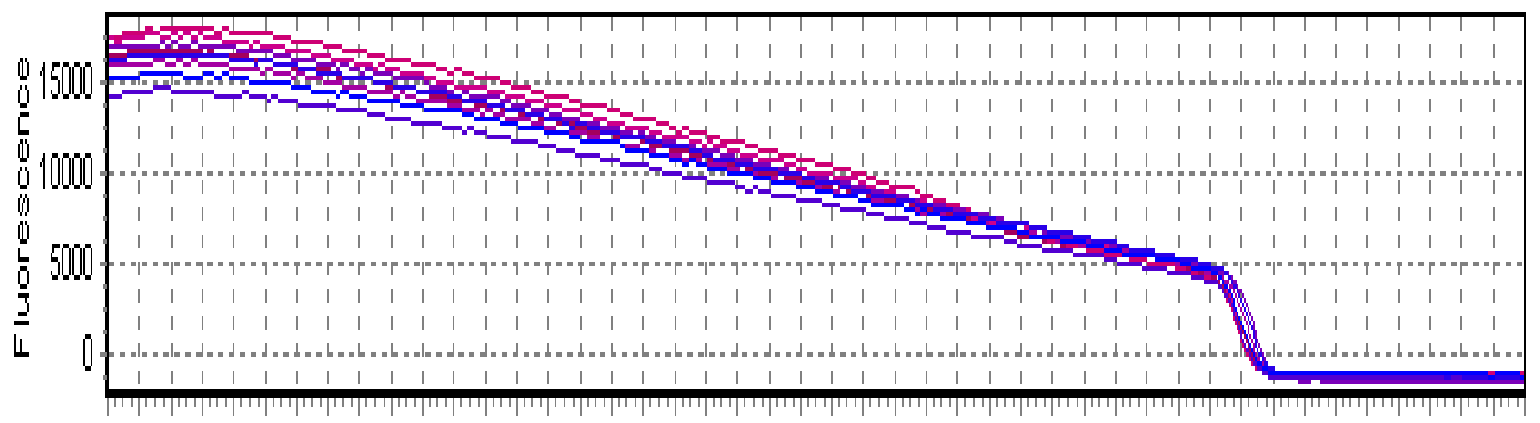

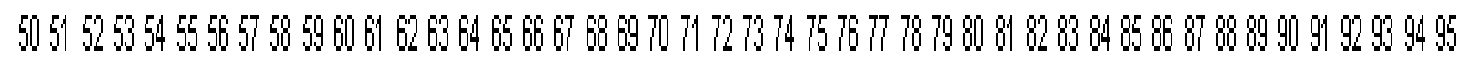
Temperdure [0]

Abb.3.1: Exemplarische Schmelzkurve einer Gradienten-PCR. Ordinate: Fluoreszenzeinheiten (RFU)

In einer grafischen Darstellung der Schmelzkurve als negative erste Ableitung lassen sich grafische Ausschläge (Peaks) erkennen. Es wurde die AnnealingTemperatur gewählt, bei der der Peak am eindeutigsten war.

Jede getestete Annealing-Temperatur kann einem Peak zugeordnet werden. Es wurde die Temperatur gewählt, bei der der Ausschlag am höchsten war. 


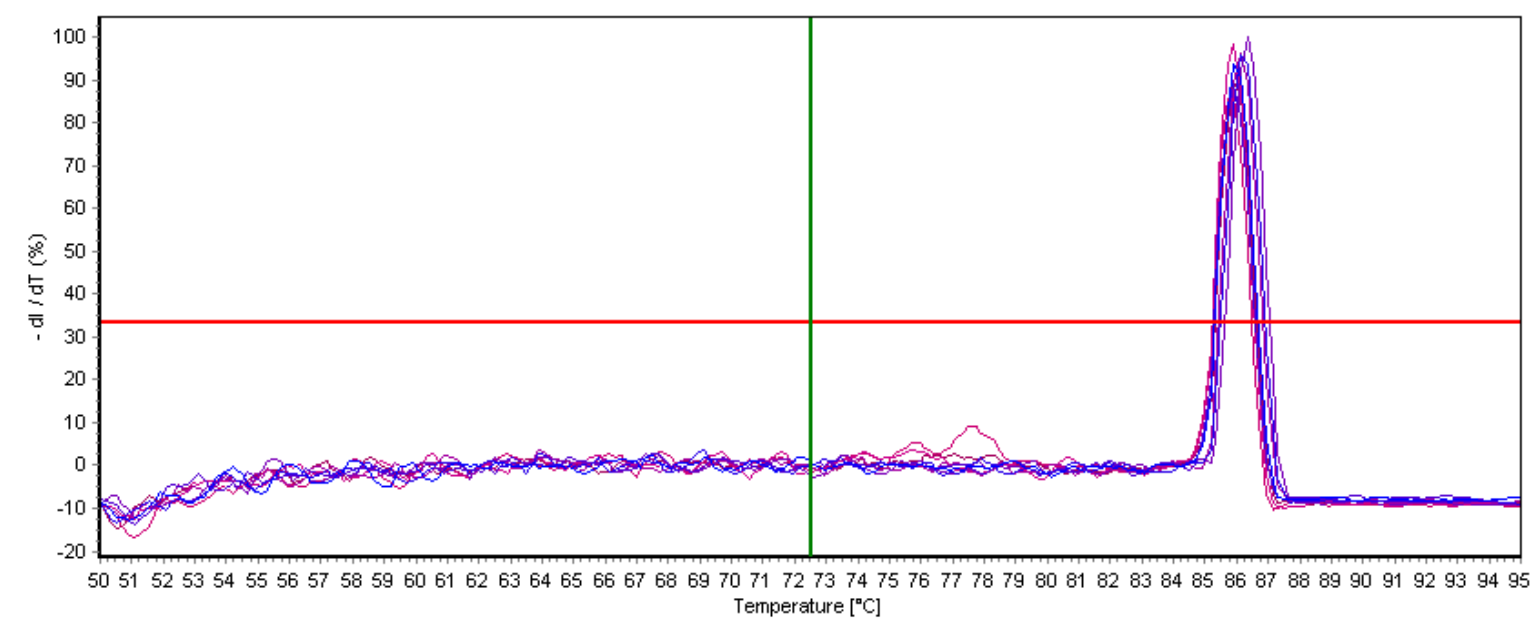

Threshold: $33 \%$

Abb.3.2: Beispiel der Schmelzkurve einer Gradienten-PCR. Ordinate: Änderung der Fluoreszenzintensität: -dl/dT (\%)

Das PCR-Produkt wurde an die Sequence Laboratories Göttingen GmbH geschickt, wo die Basenabfolge analysiert wurde. Das Ergebnis der Analyse wurde mit der NCBI-Nukleotiddatenbank verglichen; so konnte sichergestellt werden, dass das PCR-Produkt dem gesuchten Zielgen entspricht. Es wurden nur solche Primer eingesetzt, bei denen dies der Fall war.

\subsubsection{Durchführung der qRT-PCR}

Zur Durchführung der qRT-PCR wurde ein Mastercyclerß ep realplex 2 (Fa. Eppendorf, Hamburg) benutzt. Ein Well einer 96-Well-Platte wurde nach folgendem Schema beschickt:

\begin{tabular}{|l|l|}
\hline Substanz & Menge in $\boldsymbol{\mu l}$ \\
\hline cDNA einer Probe & 1 \\
\hline RNase freies Wasser & 2,5 \\
\hline Primer (for + rev) & 2 \\
\hline $\begin{array}{l}\text { QuantiTect SYBR Green PCR 4,5 } \\
\text { Master Mix (Fa. Qiagen, Hilden) }\end{array}$ & \\
\hline
\end{tabular}

Tab.3.2: Pipettieransatz pro Gen und Well 
Die Wells wurden mit transparenten Flatcaps verschlossen und kurz zentrifugiert. Dies gewährleistete, dass sich der gesamte Ansatz im Boden des Wells befindet. Es wurden immer drei Wells pipettiert und drei PCRs durchgeführt, sodass zu jedem Gen und jeder Probe insgesamt 9 Ergebnisse aus 3 unterschiedlichen PCR-Durchläufen vorlagen. Am Ende jeder PCR wurde eine Schmelzkurvenanalyse durchgeführt, um zu gewährleisten, dass keine anderen als die gesuchten PCR-Produkte entstanden waren.

Das Programm des Mastercyclers ${ }^{\circledR}$ der PCR lautete wie folgt:

\begin{tabular}{llll} 
& Dauer & Temperatur in ${ }^{\circ} \mathbf{C}$ & Zyklenanzahl \\
\hline Initiale Denaturierung & $3 \mathrm{~min}$ & 95 & 1 \\
\hline Denaturierung & $20 \mathrm{~s}$ & 95 & 45 \\
Anlagerung & $20 \mathrm{~s}$ & Primer abhängig & 45 \\
Verlängerung & $20 \mathrm{~s}$ & 72 & 45 \\
\hline Schmelzkurve & Ramptime 20 s & $50-95$ & 1
\end{tabular}

Tab.3.3: Verwendetes PCR-Programm des Mastercycler® ep realplex ${ }^{2}$

\subsubsection{Effizienzkorrigierte Auswertung nach Pfaffl}

Um Aussagen über die in den Proben enthaltene Konzentration von mRNA treffen zu können, mussten die qRT-PCR-Ergebnisse quantifiziert werden. Dies kann entweder relativ oder absolut erfolgen. Die absolute Variante erfolgt anhand einer Kalibrierungskurve, welche auf einer Verdünnungsreihe von z. B. RT-PCR Produkten basiert (Morrison et al. 1998).

\subsubsection{Relative Quantifizierung}

Bei der relativen Quantifizierung betrachtet man keine absoluten Werte, sondern es wird die Expression des untersuchten Gens mit der Expression des sogenannten Housekeeping-Gens, eines Gens, welches in allen Zellen gleichmäßig exprimiert wird, verglichen. Man bezeichnet dies auch als Norma- 
lisierung. Dadurch wird die Varianz der Expressionsergebnisse reduziert, denn Fehler bei der reversen Transkription oder Unterschiede bei der RNA-Extraktion einer Probe betreffen dadurch sowohl das Ziel- als auch das HousekeepingGen. Durch die Berechnung der Effizienz des eingesetzten Primers lässt sich die relative Quantifizierung weiter verbessern.

In der vorgelegten Arbeit wurde als Housekeeping-Gen Beta-Aktin gewählt; dieses war in allen untersuchten Proben gleichmäßig exprimiert. Die relative Expression des untersuchten Gens wird auf ein Kontrollprobenmaterial bezogen. Dieses Probenmaterial entstammte dem Kieferwinkel der Maus. Die Berechnung der Expressionsunterschiede erfolgte über das $\Delta \Delta$ ct-Modell bzw. über das effizienzkorrigierte Modell mit folgenden mathematischen Formeln:

$$
\begin{gathered}
\Delta c t=c t \text { Zielgen }-c t \text { Referenzgen } \\
\Delta \Delta c t=\Delta c t \text { Probe }-\Delta c t \text { Kontrolle } \\
\text { Ratio }=2^{-\Delta \Delta c t}
\end{gathered}
$$

Dieses Modell setzt allerdings voraus, dass in jedem Zyklus der qRT-PCR die vorhandene DNA exakt verdoppelt wird, was jedoch nicht der Realität entspricht. Daher muss man die unterschiedliche Effizienz in die Berechnung mit einbeziehen, man spricht vom effizienzkorrigierten $\Delta \Delta$ ct- Modell (Pfaffl 2001). Dieses sieht folgendermaßen aus:

$$
\text { Ratio }=\frac{\left(E_{\text {Zielgen }}\right)^{\Delta c t_{\text {Zielgen }}(\text { Kontrolle }- \text { Probe })}}{\left(E_{\text {Referenzgen }}\right)^{\Delta c t_{\text {Referenzgen }}(\text { Kontrolle }- \text { Probe })}}
$$

\subsubsection{Effizienzbestimmung}

Zur Bestimmung der Effizienz der Primer wurden die eingesetzten Proben verdünnt und mit den Ergebnissen der qRT-PCR eine Standardkurve erstellt. Die Verdünnungsreihe erfolgte 1:1, 1:10, 1:100 und 1:1000. Die Verdünnung 
wird in einer logarithmischen Funktion gegen den mittleren ct-Wert der Verdünnungsreihe aufgetragen. Anschließend wird die Steigung der Regressionskurve ermittelt. Die Effizienz berechnet sich danach mit der Formel

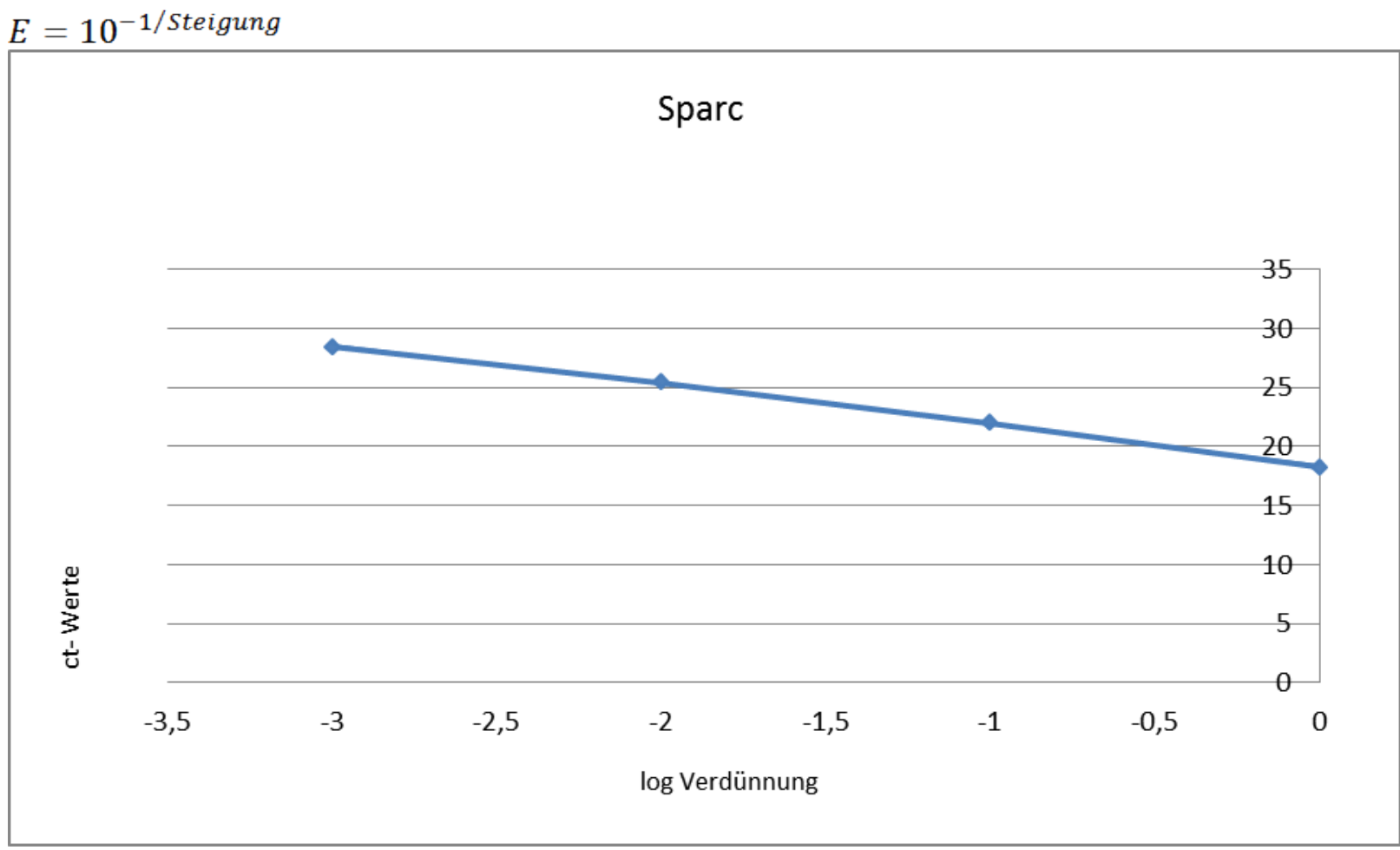

Abb.3.3: Standardkurve zur Bestimmung der Primereffizienz am Beispiel des Primers für das Gen Sparc

\subsection{Lichtmikroskopischer Nachweis von Osteocalcin, Osteopontin und Osteonektin mittels Immunhistochemie im Tuber maxillae und der Tibia}

\subsubsection{Probenmaterial}

\subsubsection{Gewinnung des Alveolarknochens}

Im Zuge der Weisheitszahnextraktion im Oberkiefer bei zwei männlichen Patienten im Alter zwischen 20 und 40 Jahren in einer Zahnarztpraxis in Goslar kam es jeweils zum Abriss des Tuber maxillae. Die Zähne waren kariesfrei und das Parodontium gesund. Die Patienten wurden über die Hintergründe der Studie aufgeklärt und erklärten sich mit der Verwendung des Knochengewebes 
einverstanden. Die Verwendung des Materials wurde durch die Ethikkommission der Medizinischen Fakultät der Georg-August-Universität Göttingen genehmigt.

Abb.3.4: Abriss und Fraktur des Tuber maxillae (Schwenzer und Ehrenfeld 2009, S. 31): Der Knochen befindet sich noch am extrahierten Weisheitszahn.

Der sich noch am extrahierten Zahn befindliche Oberkieferknochen wurde mit einem Hebel nach Bein und einer Hohlmeißelzange nach Luer abpräpariert und umgehend zur Immersionsfixierung in eine $5 \%$ gepufferte Formaldehydlösung (Fa. Fischar, Saarbrücken) gegeben.

\subsubsection{Herkunft des Tibiaknochens}

Der Tibiaknochen stammt von zwei Patienten im Alter zwischen 65-75 Jahren, welche eine Knietotalendoprothese erhielten. Die Probanden wurden vor dem Eingriff über die Verwendung der Proben aufgeklärt und gaben hierzu ihr schriftliches Einverständnis. Dies wurde durch die Ethikkommission der Medizinischen Fakultät der Georg-August-Universität Göttingen genehmigt. Unverzüglich nach Entnahme wurden die Proben in PBS-Lösung gelagert. Nach einer makroskopischen Beurteilung wurden die Bereiche verwendet, die als noch gesund bewertet wurden. 


\subsubsection{Einbettung der Präparate}

Nach der Fixierung in Formalin musste der Knochen entkalkt werden, damit Gewebeschnitte angefertigt werden konnten. Hierzu wurden die Präparate 6 Wochen in Ethylendiamintetraessigsäure (EDTA) gelagert. EDTA ist ein Chelatkomplex, der mit dem im Knochen enthaltenen $\mathrm{Ca}^{2+}$ einen Komplex bildet. Dadurch wird das Calcium aus dem Knochen gelöst und dieser wird weich.

Zur Herstellung der EDTA-Lösung wurden in $895 \mathrm{ml}$ Aqua dest. $105 \mathrm{ml} \mathrm{5N}$ $\mathrm{NaOH}$ und $200 \mathrm{~g}$ EDTA (Fa. AppliChem, Darmstadt) zwischen $50{ }^{\circ}-70^{\circ} \mathrm{C}$ gelöst. Die Proben lagerten jeweils in einer komplett gefüllten $50 \mathrm{ml}$ FalconTube auf einer Wippe. Da sich das EDTA mit der Bindung des $\mathrm{Ca}^{2+}$ verbraucht, wurde die Lösung alle 2 Tage erneuert. Mithilfe einer Nadelprobe wurde der Entkalkungsgrad überprüft.

Nach 6 Wochen wurden die Proben über Nacht in $70 \%$ Ethanol gelagert und anschließend in einen Einbettautomaten Duplex Processer, Fa. Shandon Elliot, Cheshire) gegeben, welcher folgende Schritte durchführte:

$\begin{array}{lll}\text { Pos. } 1 & 70 \% \text { Ethanol } & 3 \mathrm{~h} \\ \text { Pos. } 2 & 80 \% \text { Ethanol } & 1 \mathrm{~h} \\ \text { Pos. } 3 & 90 \% \text { Ethanol } & 1 \mathrm{~h} \\ \text { Pos. } 4 & 96 \% \text { Ethanol } & 1 \mathrm{~h} \\ \text { Pos. } 5 & 100 \% \text { Ethanol } & 2 \mathrm{~h} \\ \text { Pos. } 6 & \text { Isopropylalkohol } & 2 \mathrm{~h} \\ \text { Pos. } 7 & \text { Isopropylalkohol } & 1,5 \mathrm{~h} \\ \text { Pos. } 8 & \text { Xylol } & 30 \mathrm{~min} \\ \text { Pos. } 9 & \text { Xylol } & 45 \mathrm{~min} \\ \text { Pos. } 10 & \text { Xylol } & 45 \mathrm{~min} \\ \text { Pos. } 11 & \text { Paraplast }\left(52^{\circ} \mathrm{C}\right) & 6 \mathrm{~h} \\ \text { Pos. } 12 & \text { Paraplast }\left(56^{\circ} \mathrm{C}\right) & 7 \mathrm{~h}\end{array}$


Die Proben wurden danach in spezielle Formen gelegt und mit Paraffin übergossen, sodass sie in dieses vollständig eingebettet waren. Das Paraffin wurde dabei nur soweit erhitzt, dass gerade der Schmelzpunkt von $58{ }^{\circ} \mathrm{C}$ erreicht wurde, um eine reduzierte Immunreaktivität zu vermeiden. Vor der weiteren Verwendung härteten die Blöcke über Nacht bei Zimmertemperatur aus.

\subsubsection{Anfertigung der Gewebeschnitte}

Die ausgehärteten Paraffinblöcke wurden mithilfe eines Mikrotoms Modell 2035 Biocut (Fa. Leica/Reichert-Jung, Nussloch) in einer Dicke von $6 \mu \mathrm{m}$ geschnitten. Diese Schnitte wurden in einem $37{ }^{\circ} \mathrm{C}$ warmen Wasserbad aufgefangen,

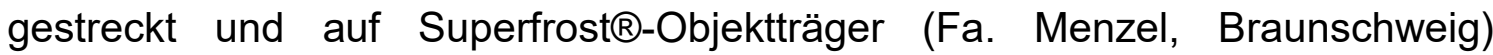
überführt. Die beschickten Objektträger wurden auf einer $37^{\circ} \mathrm{C}$ warmen Wärmeplatte für 1 ca. $2 \mathrm{~h}$ zwischengelagert. Die komplette Trocknung der Schnitte erfolgte ebenfalls bei $37^{\circ} \mathrm{C}$, über Nacht, in einem Wärmeschrank.

\subsubsection{Entparaffinierung und Rehydratation}

Zur weiteren Untersuchung musste das in den Präparaten enthaltene Paraffin entfernt und die Präparate mussten rehydriert werden, was durch Einlegen des Probenmaterials in Lösungsmittel erfolgte:

$\begin{array}{ll}\text { Xylol } & 10 \mathrm{~min} \\ \text { Xylol } & 10 \mathrm{~min} \\ 99 \% \text { Ethanol } & 5 \mathrm{~min} \\ 90 \% \text { Ethanol } & 5 \mathrm{~min} \\ 80 \% \text { Ethanol } & 5 \mathrm{~min} \\ 70 \% \text { Ethanol } & 5 \mathrm{~min} \\ 50 \% \text { Ethanol } & 5 \mathrm{~min} \\ 1 \times \text { PBS } & 10 \mathrm{~min}\end{array}$

Die Lösungen wurden frisch angesetzt. 


\subsubsection{Zur Methode der Immunhistochemie}

Als Immunhistochemie wird eine besondere Methode zur Färbung von histologischen Präparaten bezeichnet. Antikörper sind lösliche Immunglobuline (lg), die über eine antigenbindende Region (Fab-Fragment) und ein freies Fc-Fragment verfügen. Die spezifische Bindung der Antikörper an ein Antigen macht man sich zunutze. Der eingesetzte primäre Antikörper bindet mit seinem FabFragment an das gesuchte Protein, er stammt von einer anderen Spezies als die untersuchte (z. B.: Präparat = Mensch, Antikörper = Maus). Anschließend setzt man einen sekundären Antikörper ein. Im oben genannten Beispiel wäre dies ein Antikörper, der mit allen Isotypen von Immunglobulinen der Maus reagiert.

Dieser dient als Brückenantikörper zwischen dem primären und dem späteren Alkalische-Phosphatase-Anti-Alkalische-Phosphatase-Komplex (APAAP) bzw. dem Peroxidase-Anti-Peroxidase-Komplex (PAP).

Eingesetzte Enzyme sind, wie oben bereits erwähnt, entweder eine Peroxidase oder eine alkalische Phosphatase. Die Peroxidase setzt $2 \mathrm{H}_{2} \mathrm{O}_{2}$ in $\mathrm{O}_{2}$ und $\mathrm{H}_{2} \mathrm{O}$ um, wodurch 3,3'-Diaminobenzidine in ein unlösliches braunes Produkt umsetzt wird. Die Phosphatase spaltet Phosphat ab und setzt so den Farbstoff frei. Die Farbe ist dabei je nach Reagenz unterschiedlich, meist jedoch rot.

\subsubsection{Epitop-Demaskierung}

Durch die Fixierung des Präparates kann es vorkommen, dass sich Proteine untereinander vernetzen. Dies würde die Zahl der reaktiven Epitope vermindern und so die Bindungsstellen für den eingesetzten primären Antikörper vermindern. Diese Verbindungen kann man entweder durch feuchte Wärmeeinwirkung oder durch proteolytische Enzyme (Vorverdau) lösen. In diesem Fall hat sich durch Austesten ein enzymatischer Vorverdau bewährt.

Als erster Schritt wurden die Präparate mittels ProTaqs ${ }^{\circledR}$ I (Fa. Quartett, Berlin) für $20 \mathrm{~min}$ bei $60{ }^{\circ} \mathrm{C}$ vorverdaut. Als weitere Enzyme kamen Portease XXIV, Chondroitinase und Hyaluronidase zum Einsatz; sie wurden wie folgt angesetzt: 


\section{Protease 24, pH 7,6:}

25 mg Protease XXIV (Fa. Sigma-Aldrich, Steinheim)

$45 \mathrm{ml}$ Aqua dest.

$25 \mathrm{mg} \mathrm{CaCl} 2$

\section{Chondroitinase $\mathrm{ABC}$ :}

1 Unit Chondroitinase (Fa. Sigma-Aldrich, Steinheim) wurde in $1 \mathrm{ml}$ des folgenden Ansatzes gelöst:

$100 \mathrm{ml}$ Aqua dest.

$0,61 \mathrm{~g}$ Tris $\mathrm{NH}_{2} \mathrm{C}\left(\mathrm{CH}_{2} \mathrm{OH}\right)_{3}(50 \mathrm{mM}, \mathrm{pH} 8.0)$

0,492 g Natriumacetat $\mathrm{C}_{2} \mathrm{H}_{3} \mathrm{NaO}_{2}(60 \mathrm{mM})$ (Fa. Merck, Darmstadt)

0,02 g BSA $(0,02 \%)$ (Fa. Sigma-Aldrich, Steinheim)

\section{Hyaluronidase:}

Zunächst war eine Sörensen-Pufferlösung anzusetzen:

Herstellung der 0,3 M Sörensen-Pufferlösung, $\mathrm{pH}$ 7,4 aus Lösung $\mathrm{A}$ und Lösung B:

Lösung A (Kaliumdihydrogenphosphat):

$41,37 \mathrm{~g} \mathrm{KH}_{2} \mathrm{PO}_{4}$ in1 I aqua dest. (Lagerung erfolgt bei $4{ }^{\circ} \mathrm{C}$ )

Lösung B (Di-Natriumhydrogenphosphat):

42,58 $\mathrm{g} \mathrm{Na}_{2} \mathrm{HPO}_{4}$ in1 I aqua dest. lösen (Lagerung erfolgt bei

Raumtemperatur)

Zur Herstellung eines 0,3 M Sörensen-Puffers sind 18,2 ml Lösung A + 81,8 ml Lösung B zu mischen. 
6,66 ml der 0,3 M Sörensen-Pufferlösung wurden mit Aqua dest. auf $100 \mathrm{ml}$ aufgefüllt (Endkonz.: 0,02 M Phosphatpufferlsg.) und sodann zugefügt:

$0,45 \mathrm{~g} \mathrm{NaCl}(77 \mathrm{mM})$

0,01 g BSA $(0,01 \%)$

$100 \mathrm{mg}$ Hyaluronidase (1 mg/ml) (Fa. Sigma-Aldrich, Steinheim)

Für alle weiteren Schritte wurden die Objektträger in einer feuchten Kammer gelagert, um eine Austrocknung zu verhindern. Zwischen allen Schritten wurden die Präparate mit einer phosphatgepufferten Salzlösung (PBS, phosphate buffered saline) für $10 \mathrm{~min}$ gewaschen. Diese Lösung ist isotonisch und hat einen $\mathrm{pH}$ Wert von 7,4 .

1 Liter Phosphatgepufferte Salzlösung (PBS) enthält:

- $8 \mathrm{~g} \mathrm{NaCl}$

- $0,2 \mathrm{~g} \mathrm{KCl}$

- $1,44 \mathrm{~g} \mathrm{Na}_{2} \mathrm{HPO}_{4}$

- $0,24 \mathrm{~g} \mathrm{KH}_{2} \mathrm{PO}_{4}$

Von den oben beschrieben enzymhaltigen Lösungen wurden je $100 \mu \mathrm{l}$ auf jeden Schnitt pipettiert.

\subsubsection{Immundetektion}

Nach der Behandlung der Schnitte mit Enzymen konnten die Antikörper auf die Schnitte pipettiert werden. Es wurden für alle Antikörper die gleichen Schritte durchgeführt; lediglich die Konzentration dieser war unterschiedlich. Es wurden Antikörper gegen Osteocalcin vom Kaninchen (AA 40-49, Fa. BIOTREND, Köln), Osteonektin von der Maus (AON-1, Developmental Studies Hybridoma Bank, lowa City) und Osteopontin von der Maus (MPIIIB10, Developmental Studies Hybridoma Bank, lowa City) benutzt. Der Thrombospondin-1-Gehalt konnte aus technischen Gründen mit diesem Verfahren nicht bestimmt werden. 
Die verwendeten Antikörper wurden mit einer 1 \% PBS/BSA-Lösung (Bovines Serumalbumin) folgendermaßen verdünnt:
AA 40-49 1:300
AON-1 $1: 100$
MPIIIB10 1:25

Es wurden je $100 \mu \mathrm{l}$ der Antikörperlösung auf den jeweiligen Schnitt pipettiert. Dabei wurde darauf geachtet, dass der gesamte Objektträger um das Präparat herum trocken war, um ein Verlaufen der aufgebrachten Lösung zu vermeiden. So wurde eine konstante Benetzung des Präparates mit Antikörperlösung gewährleistet. Die Inkubation der Antikörper erfolgte in einer feuchten Kammer, bei $4{ }^{\circ} \mathrm{C}$ über Nacht.

Anschließend erfolgte eine 10 min Spülung in PBS. Zur Visualisierung der gesuchten Proteine, an deren Epitope nun die primären Antikörper gebunden hatten, wurde das Dako REAL ${ }^{\mathrm{TM}}$ Detection System, Alkaline Phosphatase/RED, Rabbit/Mouse (Fa. Dako, Hamburg), verwendet.

Der biotinylierte sekundäre Antikörper wurde für $15 \mathrm{~min}$ auf den Schnitten belassen, anschließend mit PBS abgespült. Danach wurde die Streptavidin Alkalische Phosphatase auf die Präparate pipettiert. Nach einer Inkubationszeit von 15 min wurde auch diese mit frischem PBS abgespült. Als letzter Schritt der Immundetektion konnte nun das Fast-Red Chromogen aufgebracht werden. Dieses wurde kurz zuvor laut Herstellerangaben frisch angesetzt, die Inkubationszeit betrug 20 min und erfolgte unter Sichtkontrolle. Durch das Spülen mit PBS wurde die Reaktion gestoppt. Das übrige Gewebe wurde mit Hämalaun nach Meyer, welches 1:4 verdünnt war, 3 min lang angefärbt. Die überschüssige Färbelösung wurde mit fließendem Leitungswasser abgespült. 


\subsubsection{Dehydratation und Eindecken}

Als Nächstes wurden die Schnitte in folgenden Schritten dehydriert:

1. $50 \%$ Ethanol $5 \mathrm{~min}$

2. $70 \%$ Ethanol $5 \mathrm{~min}$

3. $80 \%$ Ethanol $5 \mathrm{~min}$

4. $90 \%$ Ethanol $5 \mathrm{~min}$

5. $99 \%$ Ethanol $5 \mathrm{~min}$

6. Xylol $10 \mathrm{~min}$

7. Xylol $10 \mathrm{~min}$

Die Präparate wurden daraufhin mit Eukitt® (Fa. Sigma-Aldrich, Steinheim) eingedeckt und getrocknet.

\subsection{Statistische Methodik}

Die Auswertung der qRT-PCR-Daten erfolgte zunächst durch Mittelwertbildung und Berechnung der entsprechenden Standardabweichungen für das Housekeeping-Gen. Die Mittelwerte wurden sowohl aus den 9 Proben des Alveolarknochens (Referenz Sample) als auch aus den 9 Proben des Kieferwinkels (Referenz Control) gebildet.

Durch lineare Regression wurden die für die Berechnung der effizienzkorrigierten Berechnung nach Pfaffl notwendigen Primereffektivitäten bestimmt. Hierzu wurden die entsprechenden Werte aus den jeweils um den Faktor 10 verdünnten Primeransätze nach dem Logarithmus zur Basis 10 aufgetragen, wie in Abschnitt 3.1.10 beschrieben. Aus der Steigung wurde die Primereffizienz abgelesen, die dann in die nachfolgende Pfaffl-Berechnung einging. 
Die Schwellwertdurchgänge der jeweiligen Zielgene im Probenmaterial (Alveolarknochen) und im Kontrollmaterial (Kieferwinkel) konnten dann mit den Referenzwerten nach Pfaffl betrachtet werden. Für jedes Zielgen wurde dazu ebenfalls die jeweilige Primereffizienz durch lineare Regression der entsprechenden logarithmisch aufgetragenen Verdünnungsreihe abgelesen. Anschließend wurden die Einzelwerte nach Pfaffl berechnet, daraus schlussendlich der jeweilige Mittelwert gebildet. Dieser effizienzkorrigierte Wert nach Pfaffl quantifiziert die Exprimierung des Zielgens im Probenmaterial gegenüber der Zielgenexprimierung im Referenzmaterial.

Die jeweiligen Standardabweichungen wurden bestimmt, inr Betrag mit dem Abstand der Mittelwerte qualitativ verglichen. 


\section{Ergebnisse}

\subsection{Nachweis der Proteinexprimierung mit qRT-PCR}

\subsubsection{Osteocalcin}

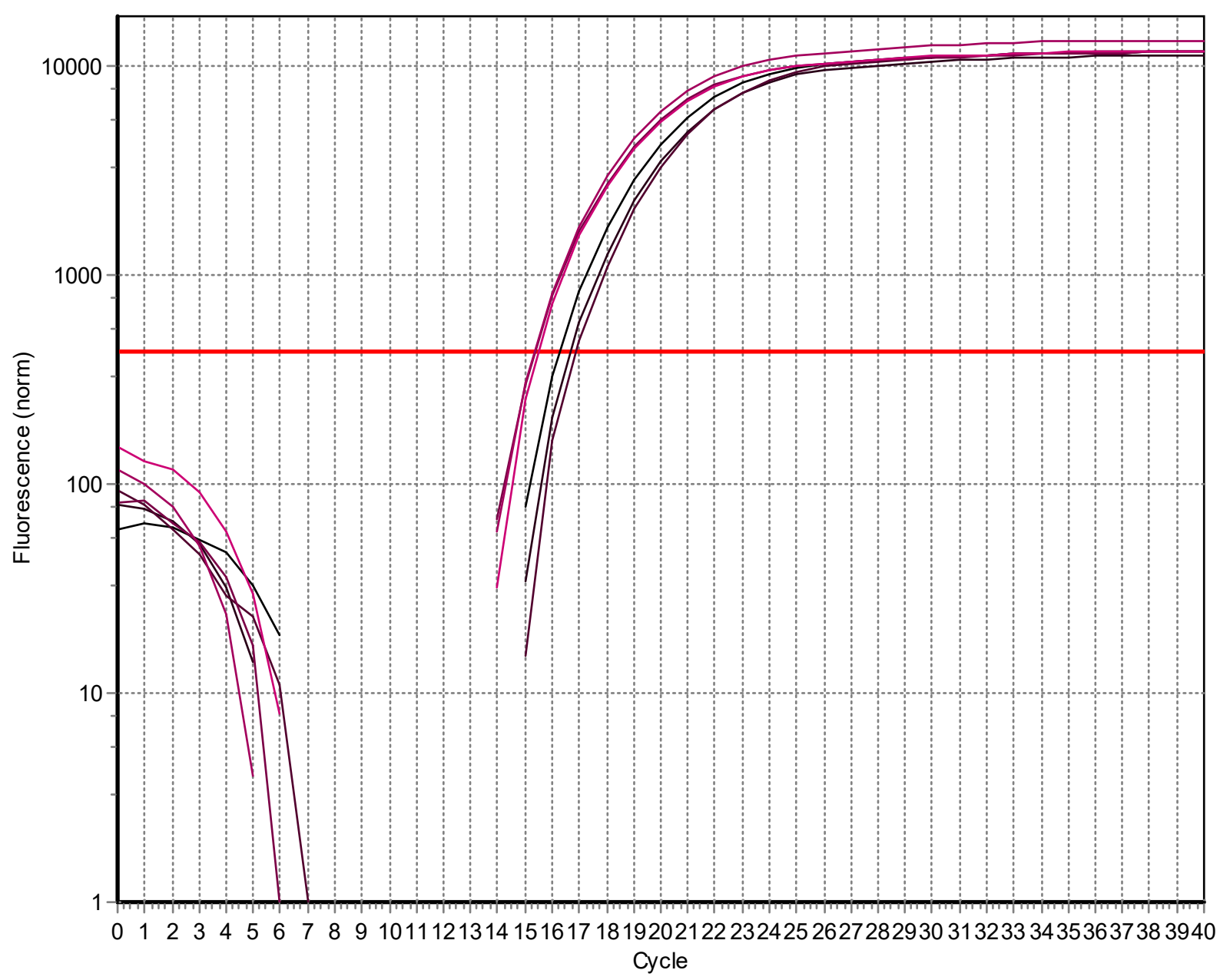

Threshold: $\quad 434$ (Noiseband)

Baseline settings: automatic, Drift correction OFF

Abb.4.1: PCR-Schmelzkurven zur Bestimmung des Gehaltes an Protein Bglap1 im Alveolarknochen (schwarze Kurvenschar) und im Kieferwinkel als Referenz (violette Kurvenschar) 


\subsubsection{Thrombospondine}

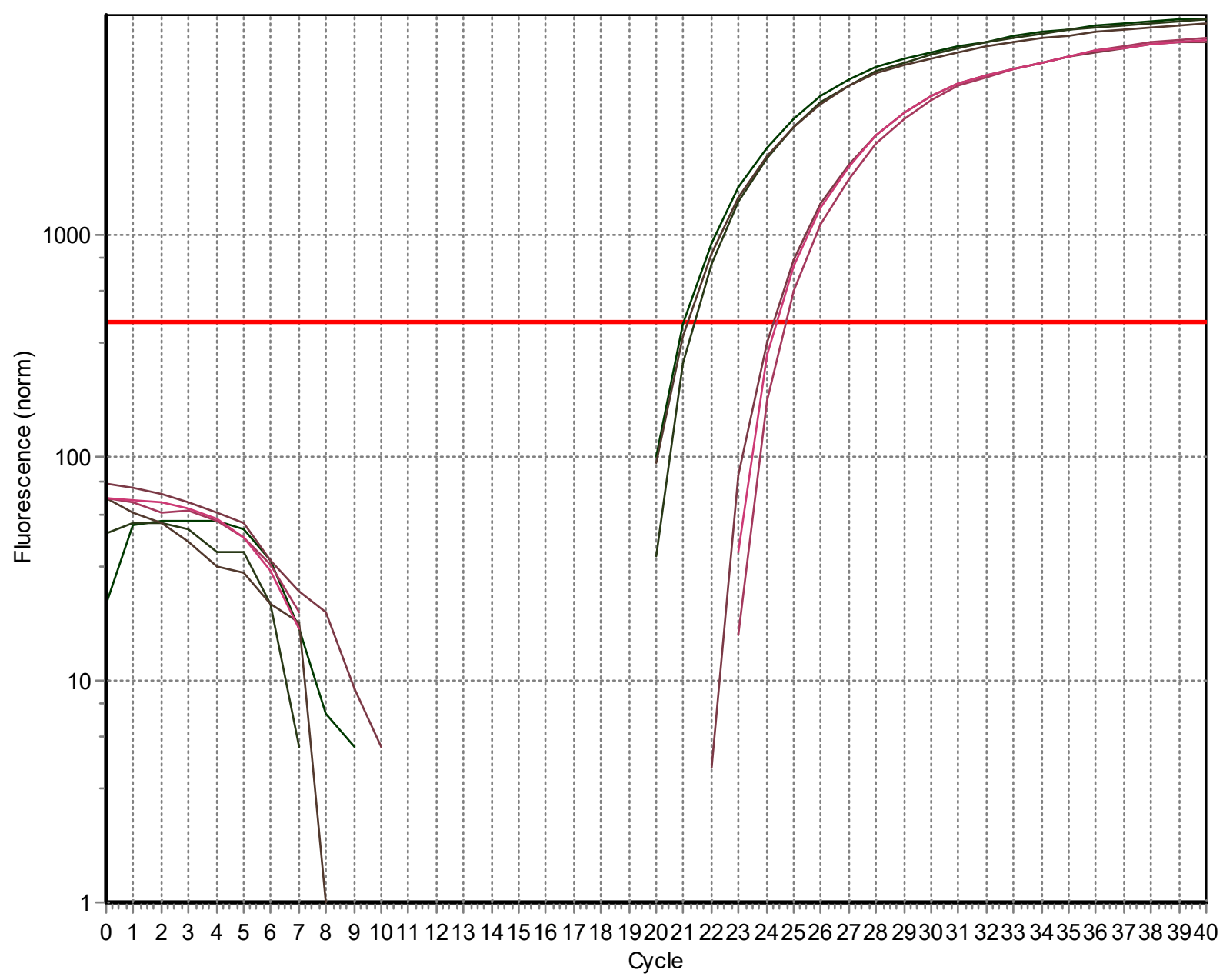

Threshold: $\quad 403$ (Noiseband)

Baseline settings: automatic, Drift correction OFF

Abb.4.2: PCR-Schmelzkurven zur Bestimmung des Gehaltes an Protein Thbs1 im Alveolarknochen (schwarze Kurvenschar) und im Kieferwinkel als Referenz (violette Kurvenschar)

Beispielhaft für die Thrombospondine wurde der Gehalt an Thrombospondin-1 bestimmt. 


\subsubsection{Osteonektin}

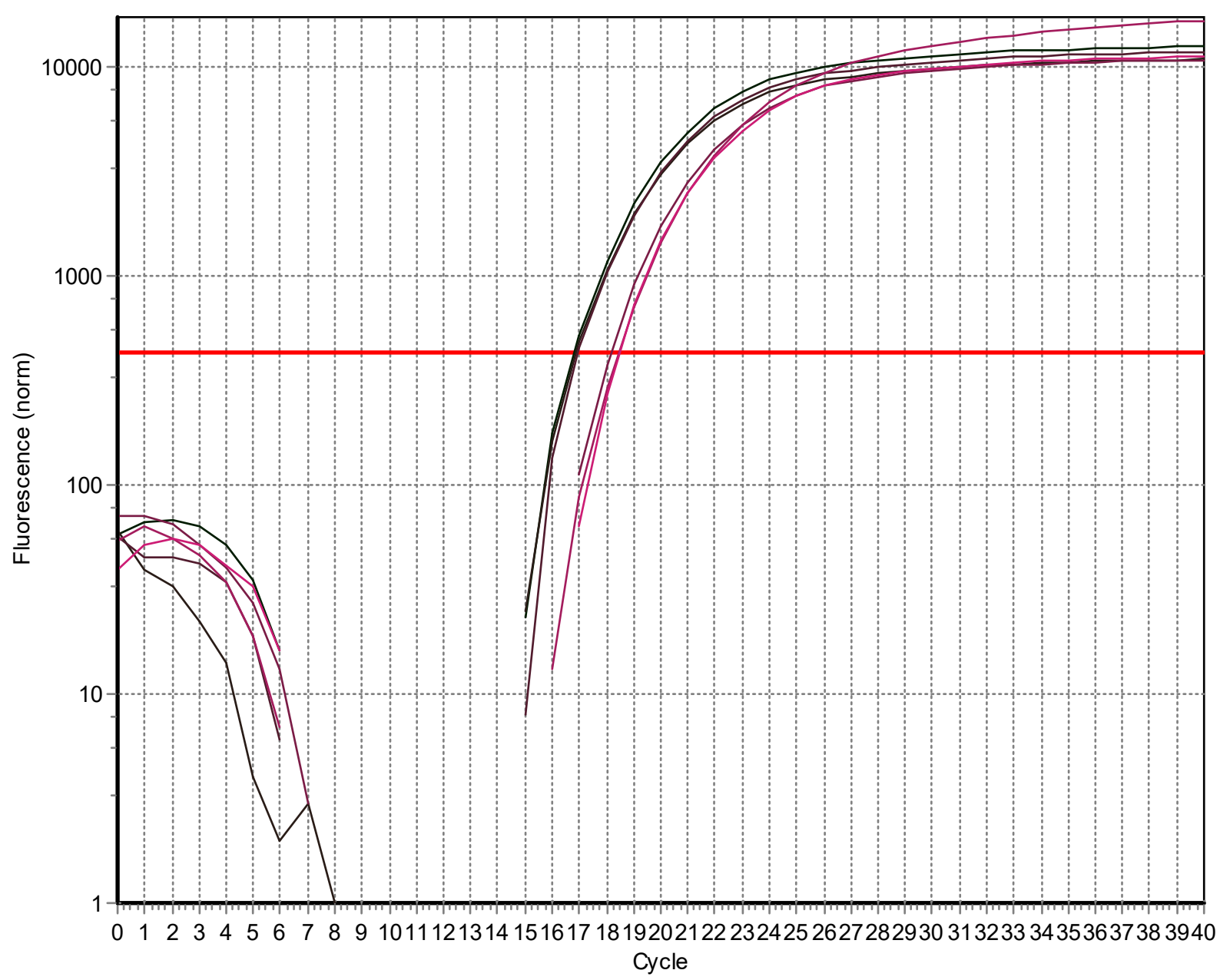

Threshold: $\quad 434$ (Noiseband)

Baseline settings: automatic, Drift correction OFF

Abb.4.3: PCR-Schmelzkurven zur Bestimmung des Gehaltes an Protein Sparc im Alveolarknochen (schwarze Kurvenschar) und im Kieferwinkel als Referenz (violette Kurvenschar) 


\subsubsection{Osteopontin}

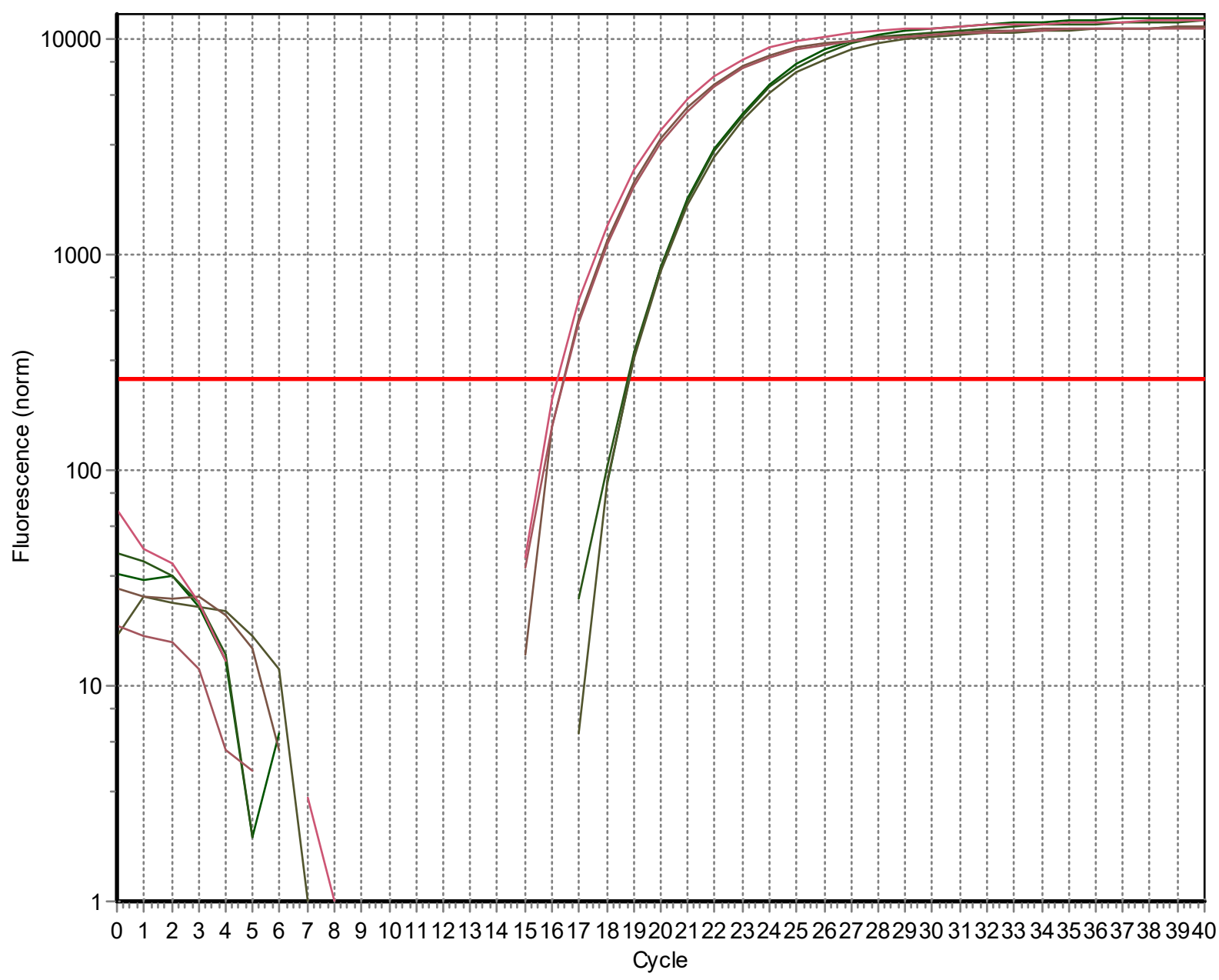

Threshold: 265 (Noiseband)

Baseline settings: automatic, Drift correction OFF

Abb.4.4: PCR-Schmelzkurven zur Bestimmung des Gehaltes an Osteopontin im Alveolarknochen (schwarze Kurvenschar) und im Kieferwinkel als Referenz (violette Kurvenschar) 


\subsection{Auswertung der qRT-PCR-Kurven nach PfaffI}

\subsubsection{Housekeeping-Gen Beta-Aktin bei Probe und Referenz}

\begin{tabular}{|lr|l|l|}
\hline \multicolumn{2}{|l|}{ Mittelw. I SD ref sample } & \multicolumn{2}{|l|}{ Mittelw. I SD ref control } \\
\hline & & & \\
Wert 1 & 17,58 & Wert 1 & 17,89 \\
Wert 2 & 17,47 & Wert 2 & 17,96 \\
Wert 3 & 17,50 & Wert 3 & 17,90 \\
Wert 4 & 17,54 & Wert 4 & 17,80 \\
Wert 5 & 17,57 & Wert 5 & 17,86 \\
Wert 6 & 17,94 & Wert 6 & 17,83 \\
Wert 7 & 17,91 & Wert 7 & 18,24 \\
Wert 8 & 17,87 & Wert 8 & 18,36 \\
Wert 9 & 18,09 & Wert 9 \\
\hline Mittelwert & 17,7188889 & Mittelwert & 17,98 \\
\hline S.D. & 0,17169741 & S.D. \\
\hline
\end{tabular}

Tab.4.1: Die PCR-Analysen für das Housekeeping-Gen im Alveolarknochen („Probe“) gegenüber dem Vorhandensein des Housekeeping-Gens im Kieferwinkel als Referenz

Zunächst wurde gemäß der Pfaffl-Methode anhand von acht qRT-PCR-Analysen der jeweilige Schwellwertdurchgang für das Housekeeping-Gen Beta-Aktin beim Referenzprobenmaterial aus dem Kieferwinkel bestimmt. Dazu wurden die jeweiligen Schnittpunkte der Schmelzkurven mit den angepassten Schwellwertlinien bestimmt und abgelesen. Aus diesen Werten wurden Mittelwert und Standardabweichung bestimmt.

In gleicher Weise erfolgte die Analyse der Schmelzkurven für die Alveolarknochenprobe. Hier wurden neun Schmelzkurven-Schwellwertschnittpunkte bestimmt. Damit ergibt sich für das Housekeeping-Gen ein Unterschied von:

$\Delta$ ct $($ Probe - Referenz $)=0,261111$

Mit der zuvor bestimmten Primereffizienz für das Housekeeping-Gen von $E=1,97$

ergibt sich durch Potenzieren mit dem Wert $\Delta$ ct (Probe - Referenz) für das Housekeeping-Gen:

$E^{\Delta \text { ct (Probe - Referenz })}=1,19368134$ 
Dies ist der fortan für die Ermittlung der Pfaffl-Ratio zu verwendende Nenner.

\subsubsection{Osteocalcin}

\begin{tabular}{|lr|}
\hline Mittelw. I SD target control \\
\hline Wert 1 \\
Wert 2 & 15,39 \\
Wert 3 & 15,36 \\
Wert 4 & 15,5 \\
Wert 5 & 15,24 \\
Wert 6 & 15,47 \\
Wert 7 & 15,4 \\
Wert 8 & 14,88 \\
Wert 9 & 15,48 \\
\hline Mittelwert & 15,03 \\
\hline S.D. & 15,3055556 \\
\hline
\end{tabular}

Tab.4.2: Die PCR-Analysen für Osteocalcin im Kieferwinkel als Referenz

Die jeweiligen Schnittpunkte der Schmelzkurven mit den Schwellwertlinien wurden für Osteocalcin an 9 Referenzproben (Kieferwinkel) bestimmt und abgelesen. Aus diesen Werten wurden wiederum der Mittelwert und die Standardabweichung bestimmt (Tabelle 4.2).

In gleicher Weise erfolgte die Analyse der Schmelzkurven für die Alveolarknochenprobe. Hier wurden neun Schmelzkurven-Schwellwertschnittpunkte bestimmt.

\begin{tabular}{|l|r|r|r|}
\hline \multicolumn{5}{|c|}{ Pfaffl-Berechnung für target sample } \\
\hline & target sample & delta ct target (control-sample) & Pfaffl \\
\hline Wert 1 & 16,31 & $-1,00444444$ & 0,41926042 \\
\hline Wert 2 & 16,7 & $-1,39444444$ & 0,31995004 \\
\hline Wert 3 & 16,91 & $-1,60444444$ & 0,27660872 \\
\hline Wert 4 & 16,9 & $-1,59444444$ & 0,27853269 \\
\hline Wert 5 & 16,9 & $-1,59444444$ & 0,27853269 \\
\hline Wert 6 & 16,91 & $-1,60444444$ & 0,27660872 \\
\hline Wert 7 & 16,99 & $-1,6844444$ & 0,26168779 \\
\hline Wert 8 & 16,94 & $-1,63444444$ & 0,27091619 \\
\hline Wert 9 & 16,96 & $-1,65444444$ & 0,26718641 \\
\hline Mittelwert & & & 0,29436485 \\
\hline S.D. & & & 0,04967605 \\
\hline
\end{tabular}

Tab.4.3: Die PCR-Analysen für Osteocalcin im Alveolarknochen 
Tabelle 4.3 zeigt für Osteocalcin neben den Schnittpunkten die Differenzen der Werte zum oben (Tabelle 4.2) bestimmten Mittelwert der Schnittpunktwerte des Kieferwinkels $\Delta$ ct (Probe - Referenz). Mit der aus den Verdünnungsreihen bestimmten Primereffizienz für das Osteocalcin von

$E=1,94$

ergaben sich durch Potenzieren mit dem jeweiligen Wert $\Delta$ ct (Probe Referenz) aus Tabelle 4.3 für das Osteocalcin die jeweiligen Zähler $\mathrm{E}^{\Delta \mathrm{ct} \text { (Probe - }}$ Referenz) und nach Division mit dem Nenner des Housekeeping-Gens ergaben sich die jeweiligen Pfaffl-Quotienten, die ebenfalls in Tabelle 4.3 dargestellt sind. Es ergab sich ein Mittelwert von:

Pfaffl-Ratio $=0,29436485$

Dies bedeutet, dass das Osteocalcin im Alveolarknochen schwächer exprimiert wird als im Kieferwinkel.

\subsubsection{Thrombospondine}

\begin{tabular}{|lr|}
\hline \multicolumn{2}{|l|}{ Mittelw. I SD target control } \\
\hline Wert 1 \\
Wert 2 & 24,25 \\
Wert 3 & 24,72 \\
Wert 4 & 24,37 \\
Wert 5 & 24,6 \\
Wert 6 & 24,62 \\
Wert 7 & 24,45 \\
Wert 8 & 24,96 \\
Wert 9 & 24,98 \\
\hline Mittelwert & 24,94 \\
\hline S.D. & 24,6544444 \\
\hline
\end{tabular}

Tab.4.4: Die PCR-Analysen für Thrombospondin im Kieferwinkel als Referenz

Die jeweiligen Schnittpunkte der Schmelzkurven mit den Schwellwertlinien wurden für Thrombospondin an 9 Referenzproben (Kieferwinkel) bestimmt und abgelesen. Aus diesen Werten wurden wiederum der Mittelwert und die Standardabweichung bestimmt (Tabelle 4.4). 
In gleicher Weise erfolgte die Analyse der Schmelzkurven für die Alveolarknochenprobe. Hier wurden neun Schmelzkurven-Schwellwertschnittpunkte bestimmt.

\begin{tabular}{|l|r|r|r|}
\hline \multicolumn{5}{|c|}{ Pfaffl-Berechnung für target sample } \\
\hline & target sample & delta ct target (control-sample) & Pfaffl \\
\hline Wert 1 & 21,02 & 3,63444444 & 9,99138371 \\
\hline Wert 2 & 21,41 & 3,24444444 & 7,6247207 \\
\hline Wert 3 & 21,18 & 3,47444444 & 8,94253892 \\
\hline Wert 4 & 21,52 & 3,13444444 & 7,06497518 \\
\hline Wert 5 & 21,44 & 3,21444444 & 7,46780622 \\
\hline Wert 6 & 21,22 & 3,43444444 & 8,69800472 \\
\hline Wert 7 & 21,82 & 2,83444444 & 5,73854302 \\
\hline Wert 8 & 21,73 & 2,92444444 & 6,10793408 \\
\hline Wert 9 & 21,68 & 2,97444444 & 6,32332991 \\
\hline Mittelwert & & & 7,551026273 \\
\hline S.D. & & & 1,428752189 \\
\hline
\end{tabular}

Tab.4.5: Die PCR-Analysen für Thrombospondin im Alveolarknochen

Tabelle 4.5 zeigt für Thrombospondin neben den Schnittpunkten die Differenzen der Werte zum oben (Tabelle 4.4) bestimmten Mittelwert der Schnittpunktwerte des Kieferwinkels $\Delta$ ct (Probe - Referenz). Mit der aus den Verdünnungsreihen bestimmten Primereffizienz für das Thrombospondin von

$E=2,3$

ergaben sich durch Potenzieren mit dem jeweiligen Wert $\Delta$ ct (Probe Referenz) aus Tabelle 4.5 für das Thrombospondin die jeweiligen Zähler $E^{\Delta \text { ct }}$ (Probe - Referenz) und nach Division mit dem Nenner des Housekeeping-Gens ergaben sich die jeweiligen Pfaffl-Quotienten, die ebenfalls in Tabelle 4.5 dargestellt sind. Es ergab sich ein Mittelwert von:

Pfaffl-Ratio $=7,551026273$

Dies bedeutet, dass das Thrombospondin im Alveolarknochen deutlich stärker exprimiert wird als im Kieferwinkel. 


\subsubsection{Osteonektin}

\begin{tabular}{|lr|}
\hline \multicolumn{2}{|l|}{ Mittelw. I SD target control } \\
\hline Wert 1 & 18,16 \\
Wert 2 & 18,45 \\
Wert 3 & 18,48 \\
Wert 4 & 18,3 \\
Wert 5 & 18,53 \\
Wert 6 & 18,01 \\
Wert 7 & 18,3 \\
Wert 8 & 18,24 \\
Wert 9 & 18,1 \\
\hline Mittelwert & 18,2855556 \\
\hline S.D. & 0,17791228 \\
\hline
\end{tabular}

Tab.4.6: Die PCR-Analysen für Osteonektin im Kieferwinkel als Referenz

Die jeweiligen Schnittpunkte der Schmelzkurven mit den Schwellwertlinien wurden für Osteonektin an 9 Referenzproben (Kieferwinkel) bestimmt und abgelesen. Aus diesen Werten wurden wiederum der Mittelwert und die Standardabweichung bestimmt (Tabelle 4.6).

In gleicher Weise erfolgte die Analyse der Schmelzkurven für die Alveolarknochenprobe. Hier wurden neun Schmelzkurven-Schwellwertschnittpunkte bestimmt.

\begin{tabular}{|l|r|r|r|}
\hline \multicolumn{5}{|c|}{ Pfaffl-Berechnung für target sample } \\
\hline & target sample & delta ct target (control-sample) & Pfaffl \\
\hline Wert 1 & 16,84 & 1,44555556 & 2,28174538 \\
\hline Wert 2 & 16,9 & 1,38555556 & 2,18879647 \\
\hline Wert 3 & 16,98 & 1,30555556 & 2,07072764 \\
\hline Wert 4 & 17,3 & 0,98555556 & 1,65879753 \\
\hline Wert 5 & 16,93 & 1,35555556 & 2,14375169 \\
\hline Wert 6 & 16,95 & 1,3355556 & 2,11423803 \\
\hline Wert 7 & 17,31 & 0,97555556 & 1,64733938 \\
\hline Wert 8 & 17,35 & 0,93555556 & 1,6022928 \\
\hline Wert 9 & 17,09 & 1,19555556 & 1,91871151 \\
\hline Mittelwert & & & 1,95848894 \\
\hline S.D. & & & 0,26072035 \\
\hline
\end{tabular}

Tab.4.7: Die PCR-Analysen für Osteonektin im Alveolarknochen 
Tabelle 4.7 zeigt für Osteonektin neben den Schnittpunkten die Differenzen der Werte zum oben (Tabelle 4.6) bestimmten Mittelwert der Schnittpunktwerte des Kieferwinkels $\Delta$ ct (Probe - Referenz). Mit der aus den Verdünnungsreihen bestimmten Primereffizienz für das Osteocalcin von

$E=1,97$

ergaben sich durch Potenzieren mit dem jeweiligen Wert $\Delta$ ct (Probe Referenz) aus Tabelle 4.3 für das Osteocalcin die jeweiligen Zähler $E^{\Delta \text { ct (Probe - }}$ Referenz) und nach Division mit dem Nenner des Housekeeping-Gens ergaben sich die jeweiligen Pfaffl-Quotienten, die ebenfalls in Tabelle 4.7 dargestellt sind. Es ergab sich ein Mittelwert von:

Pfaffl-Ratio $=1,95848894$

Dies bedeutet, dass das Osteonektin im Alveolarknochen stärker exprimiert wird, als im Kieferwinkel.

\subsubsection{Osteopontin}

\begin{tabular}{|lr|}
\hline \multicolumn{2}{|l|}{ Mittelw. I SD target control } \\
\hline Wert 1 & 16,44 \\
Wert 2 & 16,47 \\
Wert 3 & 16,21 \\
Wert 4 & 16,12 \\
Wert 5 & 16,37 \\
Wert 6 & 16 \\
Wert 7 & 16,73 \\
Wert 8 & 16,72 \\
Wert 9 & 16,66 \\
\hline Mittelwert & 16,4133333 \\
\hline S.D. & 0,26438608 \\
\hline
\end{tabular}

Tab.4.8: Die PCR-Analysen für Osteopontin im Kieferwinkel als Referenz

Die jeweiligen Schnittpunkte der Schmelzkurven mit den Schwellwertlinien wurden für Osteopontin an 9 Referenzproben (Kieferwinkel) bestimmt und abgelesen. Aus diesen Werten wurden wiederum der Mittelwert und die Standardabweichung bestimmt (Tabelle 4.8). 
In gleicher Weise erfolgte die Analyse der Schmelzkurven für die Alveolarknochenprobe. Hier wurden neun Schmelzkurven-Schwellwertschnittpunkte bestimmt.

\begin{tabular}{|l|r|r|c|}
\hline \multicolumn{5}{|c|}{ Pfaffl-Berechnung für target sample } \\
\hline & target sample & delta ct target (control-sample) & Pfaffl \\
\hline Wert 1 & 18,83 & $-2,41666667$ & 0,15587634 \\
\hline Wert 2 & 18,77 & $-2,35666667$ & 0,16249575 \\
\hline Wert 3 & 18,84 & $-2,42666667$ & 0,15479963 \\
\hline Wert 4 & 19,27 & $-2,85666667$ & 0,11490185 \\
\hline Wert 5 & 19 & $-2,58666667$ & 0,13854955 \\
\hline Wert 6 & 18,95 & $-2,53666667$ & 0,14343549 \\
\hline Wert 7 & 19,23 & $-2,81666667$ & 0,11813218 \\
\hline Wert 8 & 19,2 & $-2,78666667$ & 0,12061439 \\
\hline Wert 9 & 18,97 & $-2,55666667$ & 0,14146077 \\
\hline Mittelwert & & & 0,13891844 \\
\hline S.D. & & & 0,01755911 \\
\hline
\end{tabular}

Tab.4.9: Die PCR-Analysen für Osteopontin im Alveolarknochen

Tabelle 4.9 zeigt für Osteopontin neben den Schnittpunkten die Differenzen der Werte zum oben (Tabelle 4.8) bestimmten Mittelwert der Schnittpunktwerte des Kieferwinkels $\Delta$ ct (Probe - Referenz). Mit der aus den Verdünnungsreihen bestimmten Primereffizienz für das Osteopontin von

$E=2,02$

ergaben sich durch Potenzieren mit dem jeweiligen Wert $\Delta$ ct (Probe Referenz) aus Tabelle 4.3 für das Osteopontin die jeweiligen Zähler $E^{\Delta \text { ct (Probe - }}$ Referenz) und nach Division mit dem Nenner des Housekeeping-Gens ergaben sich die jeweiligen Pfaffl-Quotienten, die ebenfalls in Tabelle 4.3 dargestellt sind. Es ergab sich ein Mittelwert von:

Pfaffl-Ratio $=0,13891844$

Dies bedeutet, dass das Osteopontin im Alveolarknochen schwächer exprimiert wird als im Kieferwinkel. 


\subsection{Immunohistologischer Nachweis von Osteocalcin, Osteonektin und Osteopontin}

Das humane Probenmaterial aus Tuber maxillae und Tibia wurde wie in Kapitel 3.3 beschrieben in jeweils gleicher Weise eingefärbt, um eine qualitative Vergleichbarkeit der Proteinkonzentrationen anhand der Intensität der Färbungen zu ermöglichen. Wie bereits mitgeteilt, konnte der Thrombospondin1-Gehalt in den untersuchten Proben mit diesem Verfahren aus technischen Gründen nicht beurteilt werden.

\subsubsection{Osteocalcin}

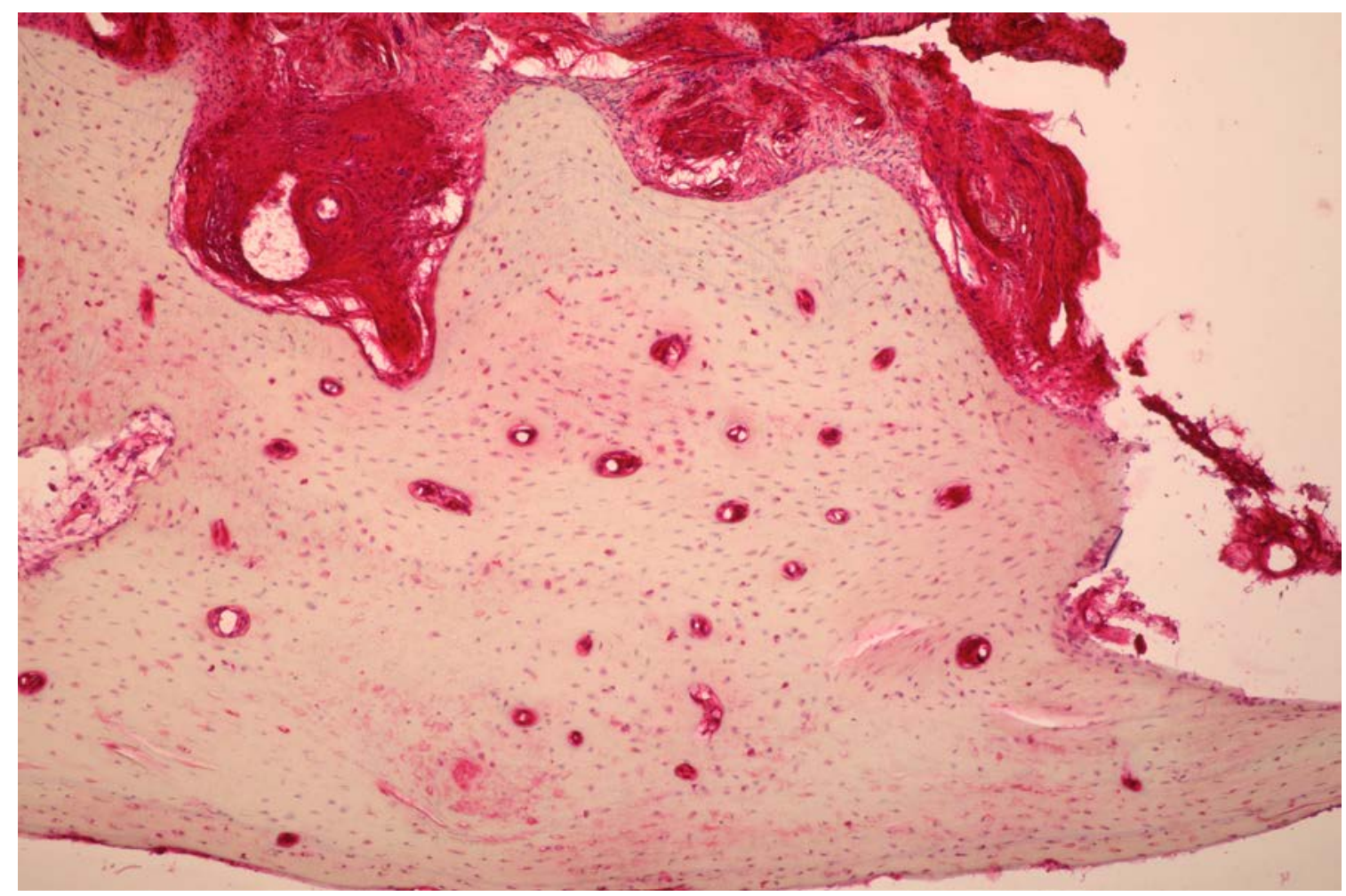

Abb.4.5: Humaner Tuber maxillae, Schnitt und Osteocalcin-Färbung (10-fache Vergrößerung). 


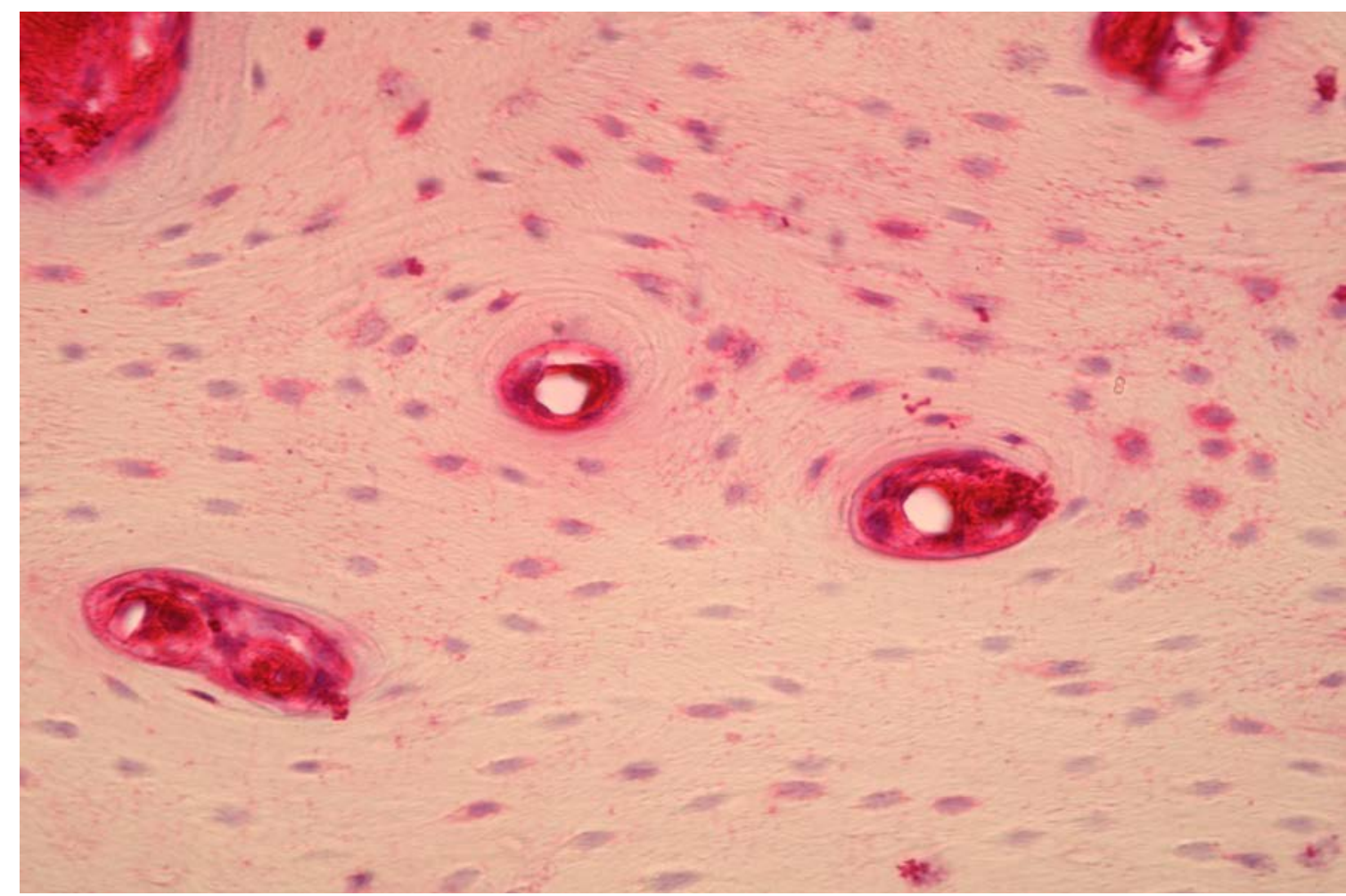

Abb.4.6: Humaner Tuber maxillae, Schnitt und Osteocalcin-Färbung (40-fache Vergrößerung)

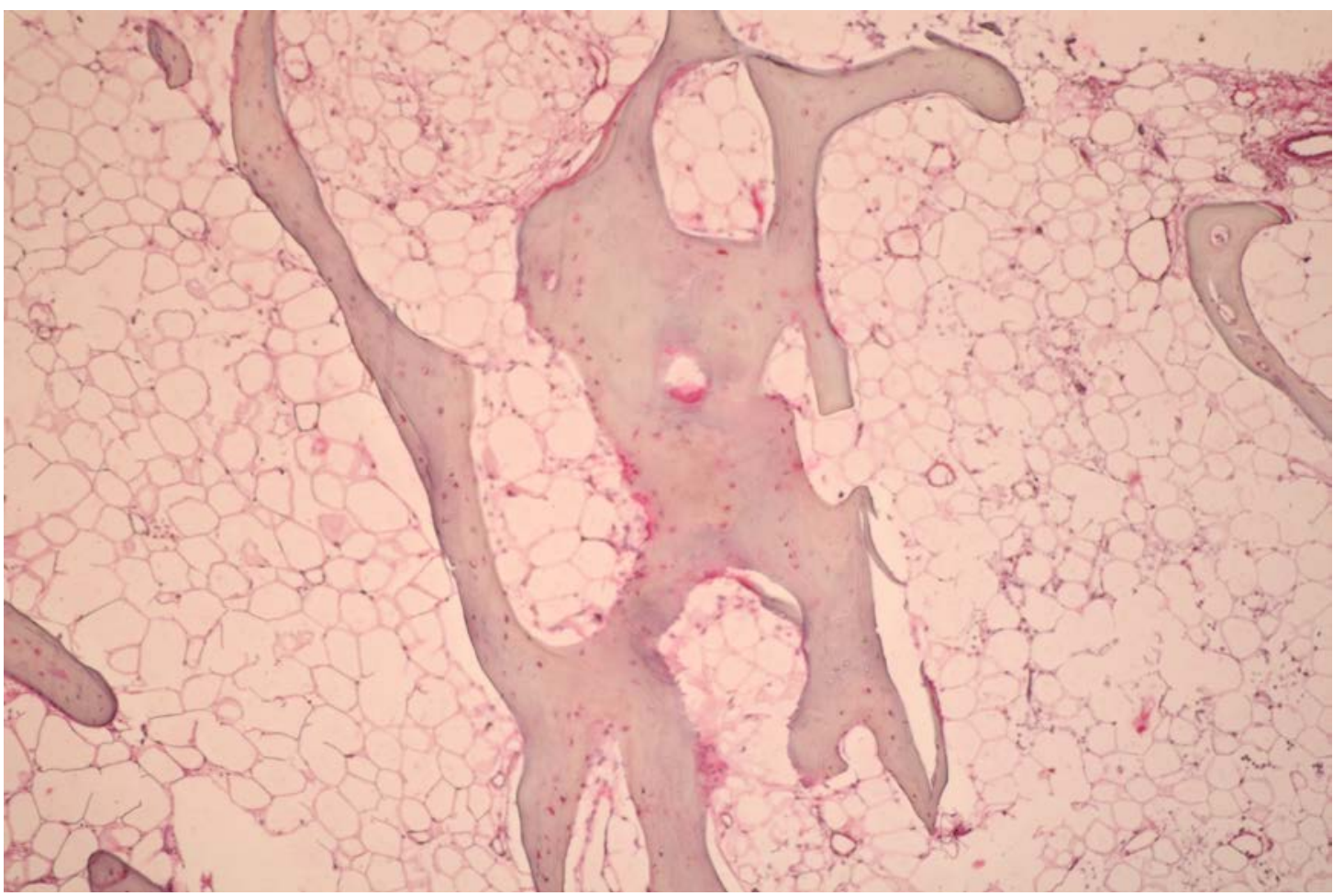

Abb.4.7: Humaner Tibiaknochen, Schnitt und Osteocalcin-Färbung (10-fache Vergrößerung): A Knorpelgewebe; C Knochenmatrix mit deutlich sichtbaren Zellrändern, die die Färbung angenommen haben. 


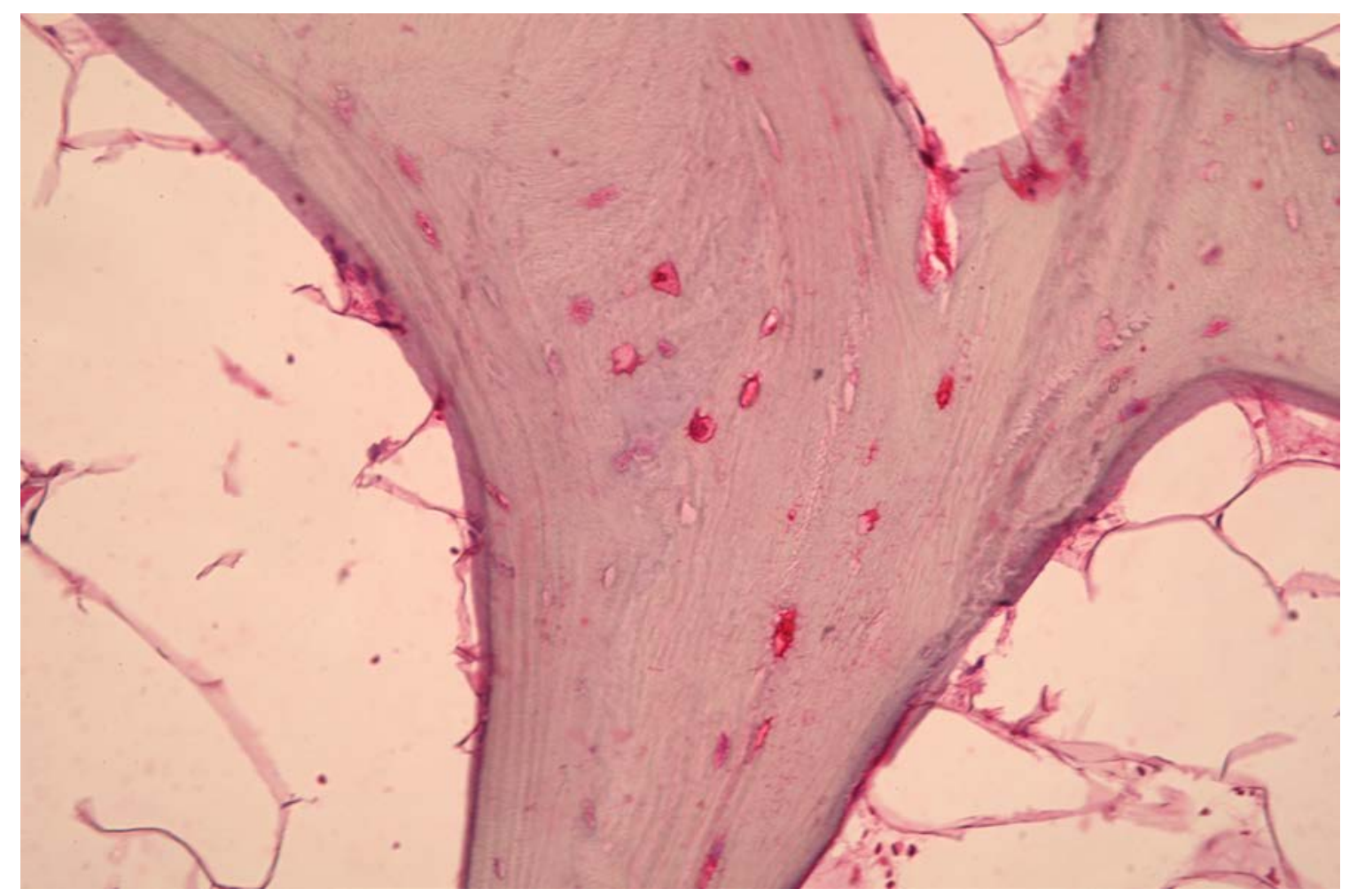

Abb.4.8: Humaner Tibiaknochen, Schnitt und Osteocalcin-Färbung (40-fache Vergrößerung):

Abbildung 4.8 zeigt die zum Vergleich herangezogene Tibia-Knochenprobe. An den Zellgrenzen sind anhand der Färbung Nachweise von Osteocalcin sichtbar. Abbildung 4.7 zeigt dieselbe Probe in der Übersicht.

Nachweise von Osteocalcin fehlen im Knochengewebe des aus einer Extraktion eines gesunden Weisheitszahnes stammenden Alveolarknochens. Abbildung 4.6 und 4.7 zeigen dieses Gewebe. Die Färbungen haften lediglich im Bindegewebe und an den durchdringenden Gefäßwänden als Artefakte, nicht jedoch im Knochengewebe selbst. Im Alveolarknochen ist anhand der Färbung wenig bis kein Osteocalcin nachweisbar. 


\subsubsection{Osteonektin}

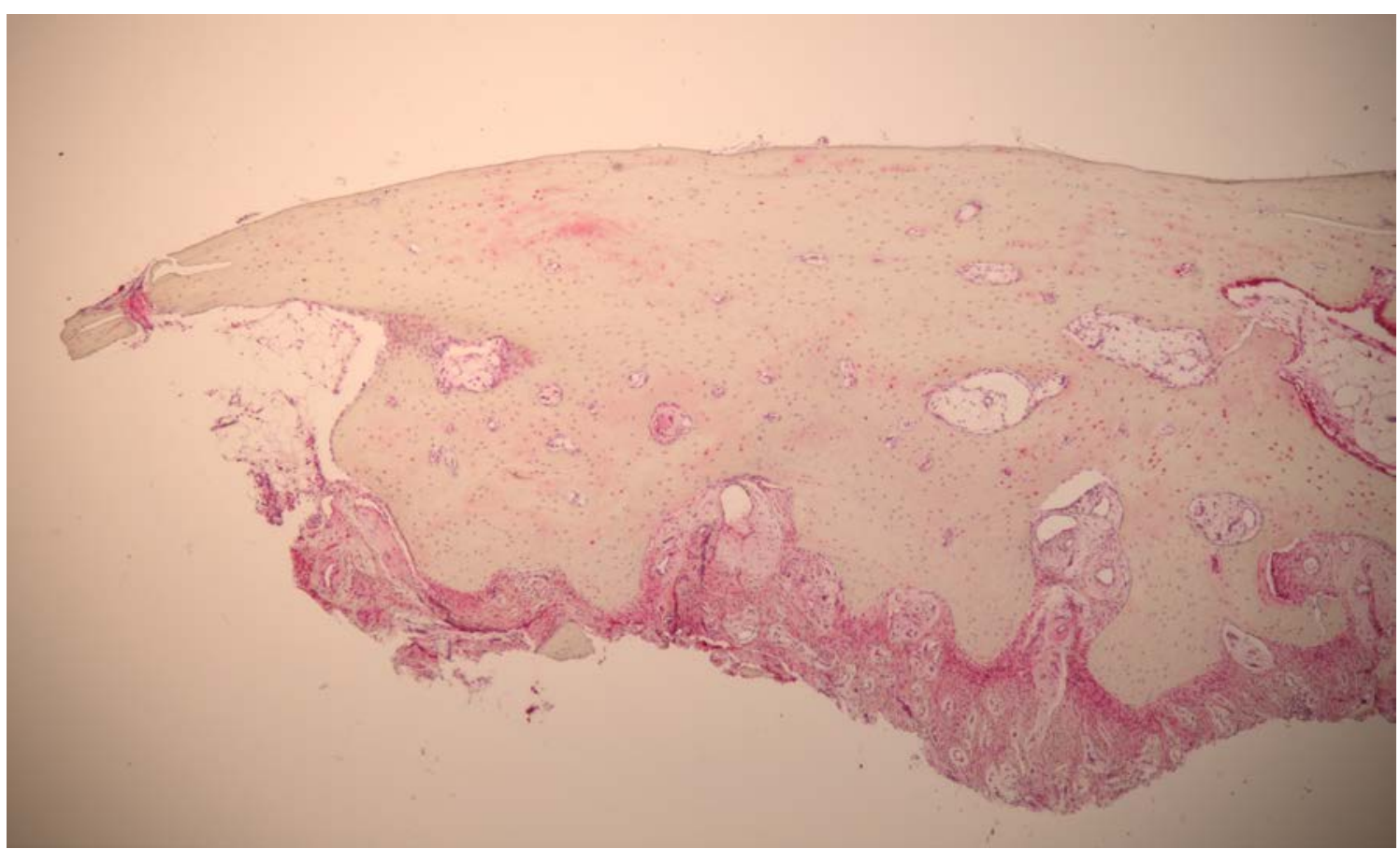

Abb.4.9: Humaner Tuber maxillae, Schnitt und Osteonektin-Färbung (4-fache Vergrößerung)

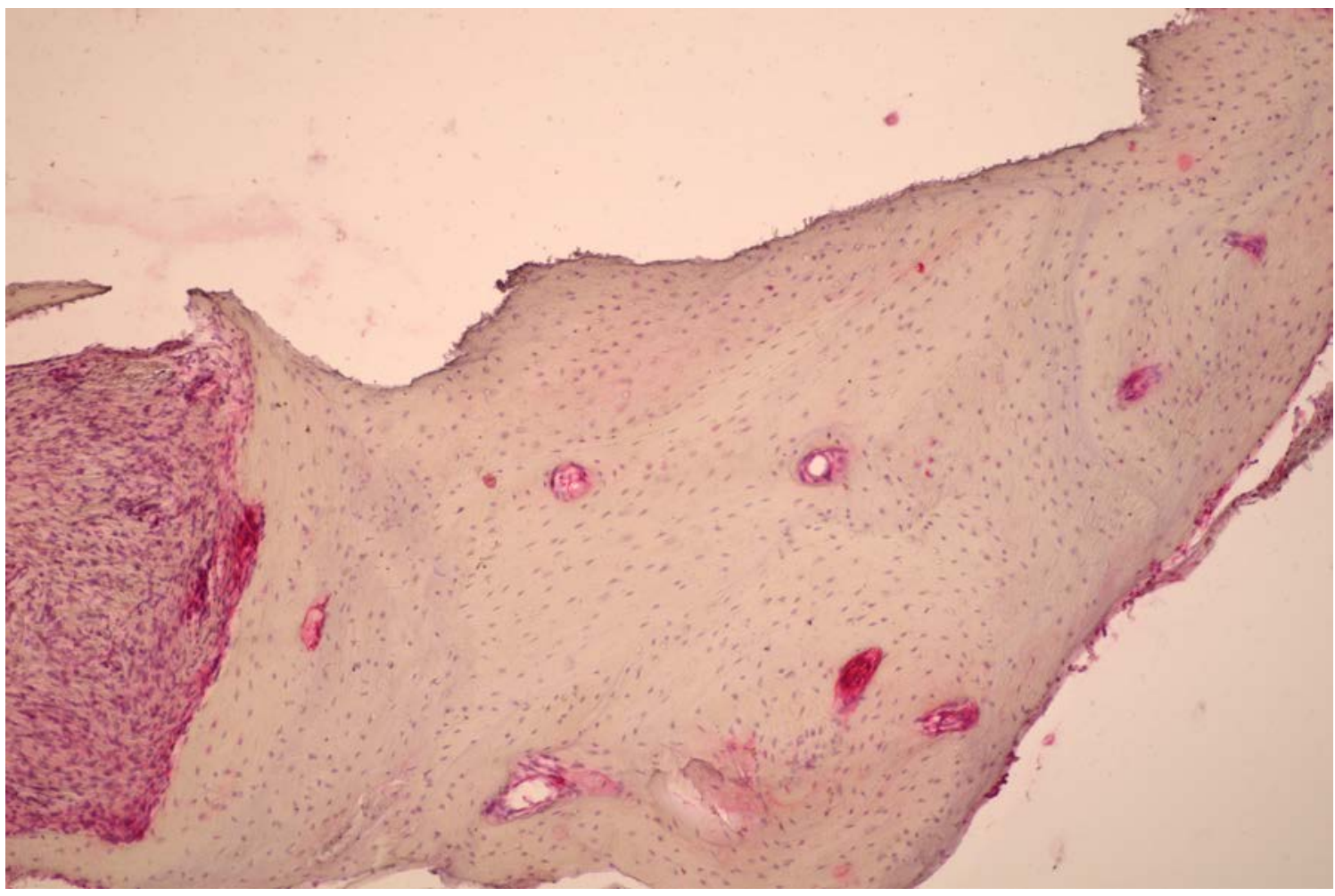

Abb.4.10: Humaner Tuber maxilae, Schnitt und Osteonektin-Färbung (10-fache Vergrößerung) 


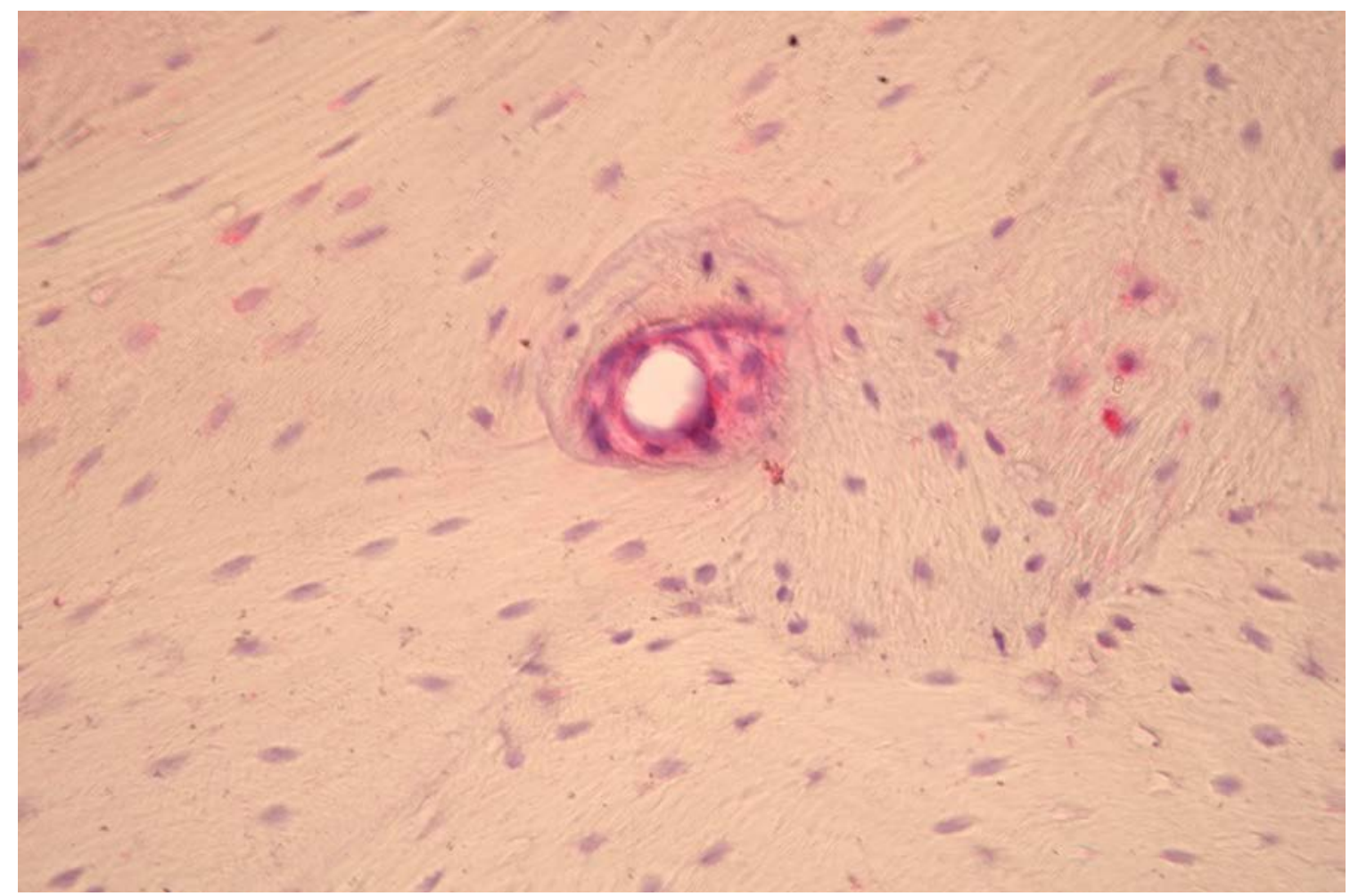

Abb.4.11: Humane Tuber maxillae, Schnitt und Osteonektin-Färbung (40-fache Vergrößerung)

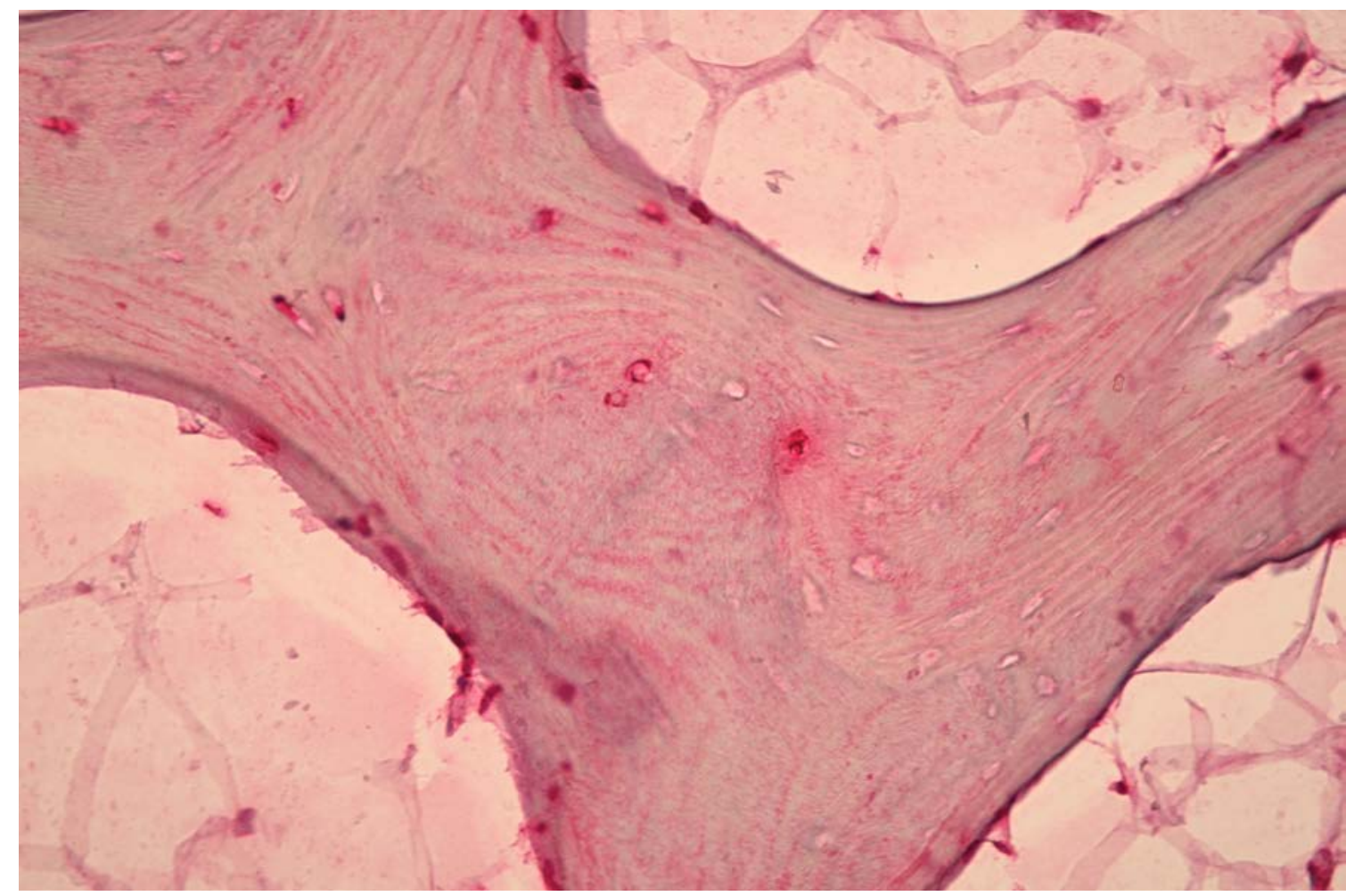

Abb.4.12: Humaner Tibiaknochen, Schnitt und Osteonektin-Färbung (40-fache Vergrößerung) 
Die Abbildungen 4.9 bis 4.11 zeigen die Alveolarknochenprobe mit OsteonektinFärbung. Der zum Vergleich herangezogene Tibiaknochen, Abbildung 4.12, zeigt eine schwache Färbung. Die Osteonektin-Färbung der Alveolarknochenprobe ist etwas stärker. Zieht man die Osteocalcin-Färbungen aus dem vorangegangenen Abschnitt mit hinzu, so erkennt man im Vergleich bei den Osteonektin-Färbungen die stärkere Färbung der Alveolarknochenproben und damit den Nachweis des Osteonekins. 


\subsubsection{Osteopontin}

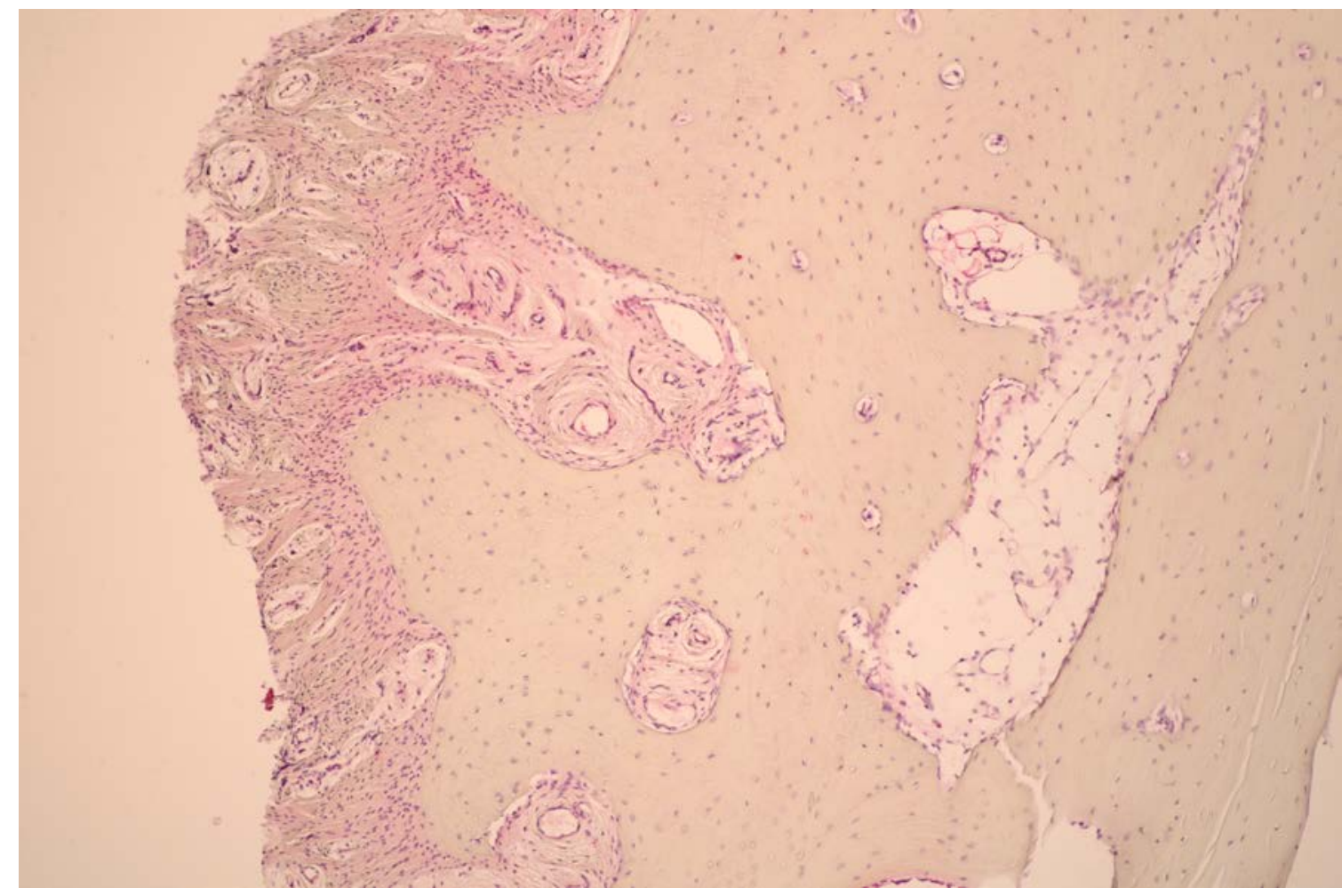

Abb.4.13: Humaner Tuber maxilae, Schnitt und Osteopontin-Färbung (10-fache Vergrößerung)

Abbildung 4.15 zeigt die zum Vergleich herangezogene Tibia-Knochenprobe. An den länglichen, strangartigen Zellgrenzen sind anhand der Färbung Nachweise von Osteopontin sichtbar. Solche Nachweise von Osteopontin fehlen im Knochengewebe des Alveolarknochens. Abbildungen 4.13 und 4.14 zeigen dieses Gewebe. Die Färbungen haften lediglich leicht im Bindegewebe und ganz schwach an den durchdringenden Gefäßwänden als Artefakte. Im Alveolarknochen ist anhand der Färbung kein Osteopontin nachweisbar. 


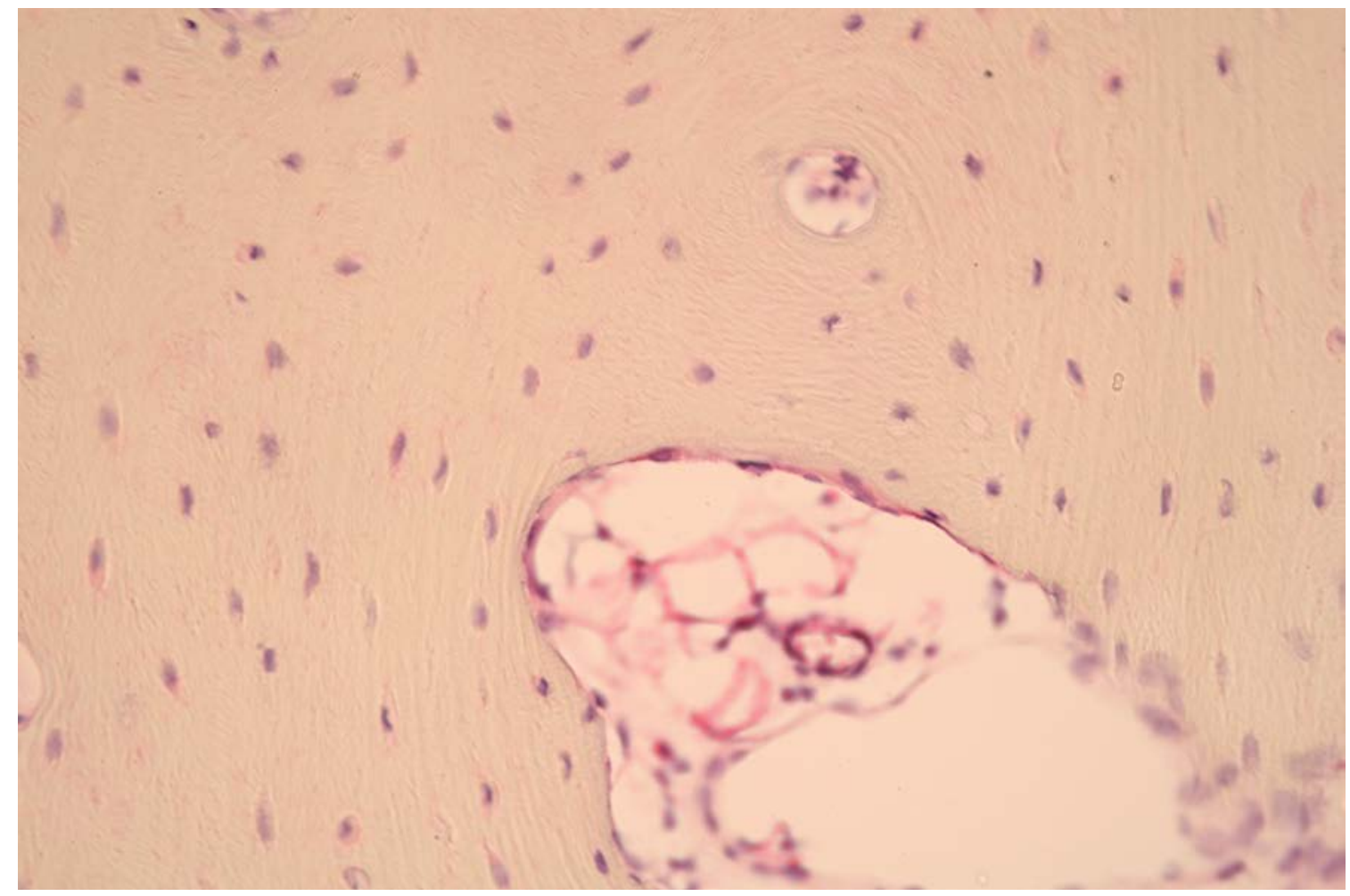

Abb.4.14: Tumaner Tuber maxillae, Schnitt und Osteopontin-Färbung (40-fache Vergrößerung)

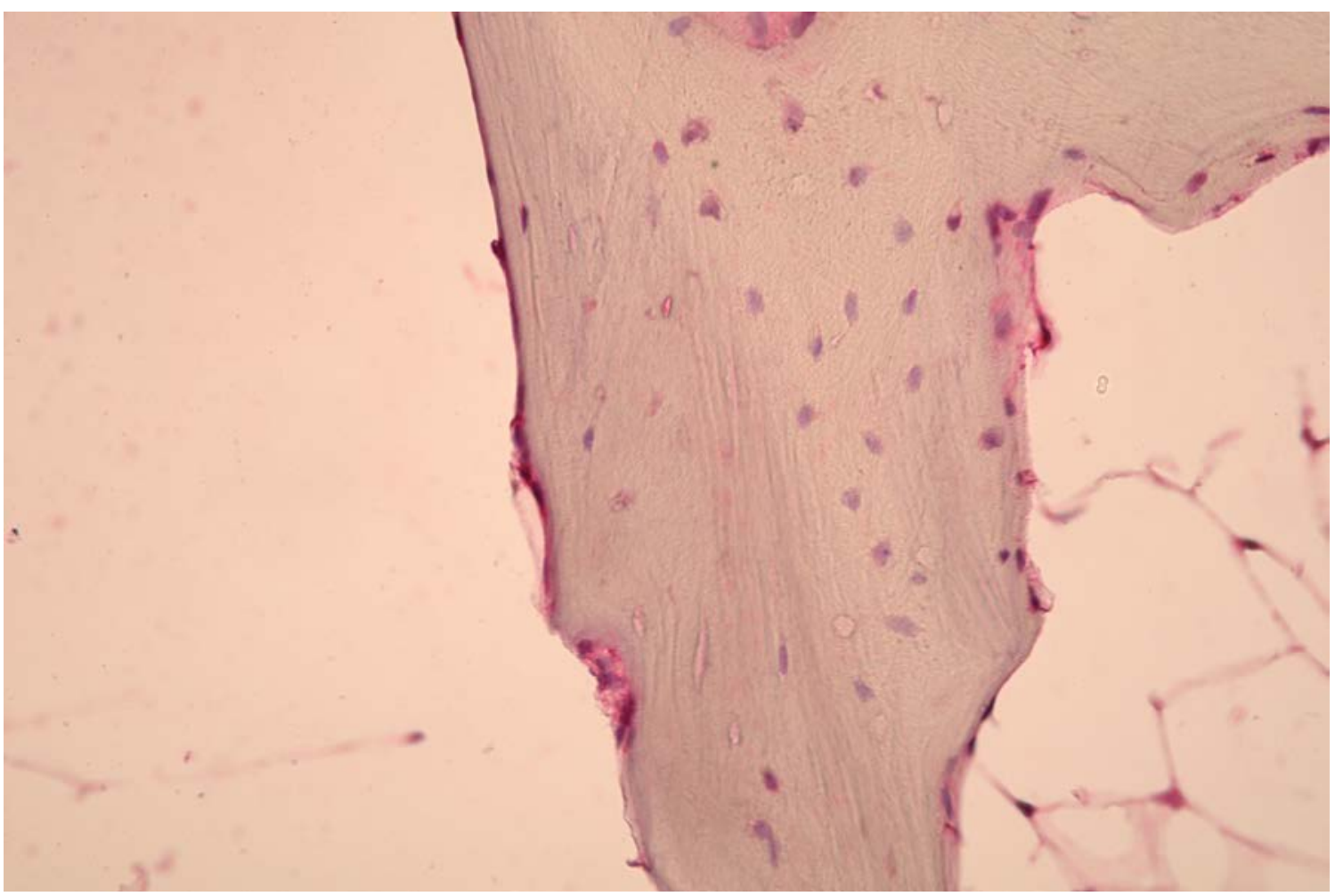

Abb.4.15: Humaner Tibiaknochen, Schnitt und Osteopontin-Färbung (40-fache Vergrößerung) 


\section{Diskussion}

Die vorliegende Arbeit befasst sich mit der Frage, ob zwischen dem Alveolarknochen und dem Knochen aus dem Kieferwinkel bzw. aus der Tibia Unterschiede bezüglich der Expression ausgewählter extrazellulärer Matrixproteine erkennbar sind.

Hierzu wurden zwei verschiedene Herangehensweisen gewählt: Im ersten Teil der Arbeit wurde murines Material aus dem Alveolarknochen und aus dem Kieferwinkel zum Nachweis der Expression der untersuchten Matrixproteine anhand einer qRT-PCR-Analyse angewendet. Im zweiten Teil wurde das Vorhandensein der genannten Matrixproteine in humanen Proben aus dem Alveolarknochen und aus der Tibia lichtmikroskopisch nach immunhistochemischer Färbung bestimmt. Die Resultate der beiden Bestimmungsverfahren wurden verglichen.

Es wurde die Expression folgender Matrixproteine untersucht: Osteonektin (Sparc), Osteopontin, Osteocalcin und Thrombospondin-1. Es zeigten sich - bei jedem der untersuchten Matrixproteine - teils deutliche Unterschiede zwischen den verglichenen Knochenarten.

\subsection{Ergebnis}

\subsubsection{Osteonektin}

In den murinen Proben wurde im Alveolarknochen fast die doppelte Menge Osteonektin im Vergleich zum Kieferwinkel nachgewiesen (Pfaffl-Ratio: 1,96). Bei der mikroskopischen Auswertung der gefärbten humanen Proben ist eine quantitative Auswertung nicht möglich, doch die Intensität der Färbung gestattet die Beantwortung der Frage, in welcher Probe Osteonektin stärker exprimiert ist. Auch anhand dieser Methode konnte gezeigt werden, dass die Expression des Osteonektins im Alveolarknochen höher ist als in der Tibia. 


\subsubsection{Osteopontin}

Bei diesem Matrixprotein waren die Verhältnisse umgekehrt. In den murinen Proben des Alveolarknochens wurde anhand der qRT-PCR ein wesentlich geringerer Osteopontingehalt ermittelt als im Kieferwinkel (Pfaffl-Ratio $=0,13$ ). Auch die mikroskopische Auswertung der humanen Proben weist sehr deutlich in die gleiche Richtung: Am zahnanhaftenden Material konnte kein Osteopontin nachgewiesen werden, während in der extrazellulären Matrix der Tibia Osteopontin deutlich in den nicht kalzifizierten Zonen visualisiert wird.

\subsubsection{Osteocalcin}

Bei der qRT-PCR-Analyse der murinen Proben fand sich im Alveolarknochen ein deutlich geringerer Osteocalcin-Gehalt im Vergleich zum Kieferwinkel (PfafflRatio: 0,29). In den humanen Proben konnte im Tuber maxillae kein Osteocalcin nachgewiesen werden, während in der Tibia sehr wohl eine entsprechende Osteocalcin-Färbung zu beobachten war. Es kann daher bestätigt werden, dass die Resultate der beiden verschiedenen Verfahren auch bezüglich des Osteocalcins übereinstimmende Rückschlüsse ermöglichen.

\subsubsection{Thrombospondine}

Der Thrombospondin-Gehalt wurde in der vorgelegten Arbeit nur an murinem Material anhand der qRT-PCR ermittelt, wobei stellvertretend für die Gruppe der fünf bekannten Thrombospondine die Expression des Thrombospondin-1 bestimmt wurde. Die Messungen ergaben, dass die ThrombospondinExpression im Alveolarknochen im Vergleich zum Kieferwinkel mehr als siebenfach erhöht war (Pfaffl-Ratio $=7,55$ ).

\subsection{Interpretation der Befunde}

Den in der vorliegenden Arbeit ermittelten Resultaten zufolge waren daher Osteonektin und Thrombospondin-1 im Alveolarknochen deutlich stärker exprimiert als im Kieferwinkel (murine Proben) bzw. in der Tibia (humane 
Proben), während Osteopontin und Osteocalcin im Alveolarknochen deutlich schwächer exprimiert waren als im Kieferwinkel bzw. in der Tibia.

Die Proteine der extrazellulären Matrix im Knochen werden zum größten Teil von Zellen der Osteoblastlinie - den Osteoblasten und Osteozyten - produziert und in die Matrix freigesetzt. Da die Aktivität der Osteoblasten in engem Zusammenhang mit dem Knochenumbau zu sehen ist (die Aktivität der Osteoklasten ebenfalls), ist es nur folgerichtig, auch die Funktion der einzelnen Matrixproteine im Zusammenhang mit dem Remodeling zu sehen. Entsprechend werden einzelne Matrixproteine auch als bone biomarker bezeichnet (Ram et al. 2015).

Unter normalen, d. h. physiologischen Bedingungen werden Knochenresorption und Knochenbildung von gekoppelten Prozessen gesteuert. Daher gehen einige Autoren davon aus, dass bereits die Bestimmung eines einzelnen Biomarkers Rückschlüsse auf den Gesamtzustand des Knochenremodelings zulassen müsste (Ram et al. 2015). Daraus ließe sich ableiten, dass die im Alveolarknochen - im Vergleich zu anderen Skelettknochen - beobachtete Steigerung der Osteonektin- und Thrombospondin-1 bei gleichzeitiger Reduktion der Osteopontin- und Osteocalcinwerte auf einen gemeinsamen Nenner gebracht werden und eine einheitliche Aussage über das Remodeling des Alveolarknochens gestatten müssten.

Um der Frage nachzugehen, ob diese Vermutung stimmt und ob bzw. wie sich der Alveolarknochen von anderen Knochen hinsichtlich der Expression der untersuchten Matrixproteine unterscheidet, ist eine nähere Betrachtung der Funktion der einzelnen Matrixproteine sinnvoll.

\subsubsection{Osteonektin}

Die exakte Funktion des Osteonektins und dessen Regulation wurden bis dato noch nicht eindeutig geklärt (Ram et al. 2015). Es wird angenommen, dass ein bestimmter Osteonektin-Spiegel für den normalen Knochenumbau sowie für die normale Entwicklung des Knochengerüsts erforderlich ist. Darauf weist der 
Umstand hin, dass bei Patienten mit Osteogenesis imperfecta weniger Osteonektin produziert wird als bei gesunden Kontrollpersonen (Delany et al. 2000). Im Tierexperiment wurde diese Vermutung untermauert: Bei OsteonektinKnockout-Mäusen ist die Zahl der Osteoklasten und Osteoblasten deutlich reduziert, der Knochenumbau ist gehemmt und es entwickelt sich eine Osteopenie (Delany et al. 2000).

Allerdings ist die Osteonektin-Expression nicht in allen Knochen des Skeletts zum gleichen Zeitpunkt vergleichbar; vielmehr wurden - in Abhängigkeit vom Knochen- bzw. Gewebetyp sowie von der jeweiligen Entwicklungsphase unterschiedliche Expressionen des Osteonektin-Gens beobachtet. So stellen sich beispielsweise bei Osteonektin-Knock-out-Zebrafischen bereits während der Embryogenese spezifische Fehlbildungen im Innenohr ein, während die Entwicklung der anderen Knochen in dieser Phase unauffällig ist. Dagegen sind Osteonektin-Knockout-Mäuse bei der Geburt phänotypisch normal; erst nach der Geburt stellt sich eine Reihe von Entwicklungsstörungen ein (Rotllant et al. 2008).

Es ist daher davon auszugehen, dass zu den Funktionen des Osteonektins der Erhalt des ausgewogenen Knochenumbaus zählt; ferner scheint eine ausreichende Osteonektin-Expression für die normale Entwicklung des Knochengerüsts entscheidend zu sein.

\subsubsection{Osteopontin}

Dem Matrixprotein Osteopontin wird eine wesentliche Rolle sowohl bei der Mineralisierung als auch bei der Knochenresorption zugeschrieben (Ram et al. 2015), allerdings wurden auch Berichte veröffentlicht, wonach Osteopontin die Mineralisierung der Knochen inhibiert (Chabas 2005).

Die Osteopontin-Expression in einer ganzen Reihe auch nicht mineralisierten Gewebes, unter anderem auch in Tumoren (Chellaiah et al. 2003; Ram et al. 2015), weist jedoch darauf hin, dass dieses Protein offenbar auch außerhalb des Knochenremodelings wichtige Funktionen hat. So ist unter anderem die 
Beteiligung des Osteopontins an der Rekrutierung von Makrophagen und Lymphozyten im Rahmen der Immunabwehr nicht spezifischer Infektionen zu nennen (Ram et al. 2015).

Unlängst wurde beschrieben, dass dieses Matrixprotein auch an der Regulierung zweier wichtiger Überlebenssignalwege maßgeblich beteiligt ist: Osteopontin aktiviert sowohl Akt, welches den Akt/mTOR-Signalweg einleitet, als auch den MAPK/ERK 1/2-Signalweg (Robertson et al. 2010). Die Aktivität dieser beiden Signalwege ist allgemein für Zellwachstum, -proliferation und motilität von entscheidender Bedeutung. Darüber hinaus verhindern diese Signalwege in aktiviertem Zustand den programmierten Zelltod (Apoptose). Aus diesem Grund spielen der PI3K/Akt/mTOR- und der MAPK/ERK 1/2-Signalweg (und somit auch deren Aktivator, das Osteopontin) eine zentrale Rolle insbesondere in jenen Zellen, die sich intensiv vermehren und proliferieren etwa in embryonalen und/oder in regenerierenden Geweben, aber auch in Tumoren.

Die Bedeutung des Osteopontins für das Knochenremodeling wurde an murinen Osteoklasten demonstriert: Es wurde beobachtet, dass Osteopontindefizienz mit einer eingeschränkten Motilität und einer Reduktion der Resorptionskapazität einherging (Chellaiah et al. 2003).

Die beschriebenen Funktionen des Osteopontins lassen erwarten, dass Zellen, in denen eine hohe Osteopontin-Expression festgestellt wurde, generell intensiver wachsen und proliferieren und über eine ausgeprägte Motilität verfügen, während Zellen mit geringerem Osteopontingehalt sich eher in einem Ruhezustand befinden.

\subsubsection{Osteocalcin}

Osteocalcin hat eine wichtige Funktion sowohl bei der Knochenresorption als auch bei der Mineralisierung des Knochens (Ram et al. 2015). Es wurde gezeigt, dass dieses Matrixprotein über die Aktivierung der Osteoklasten die Remodellierung des Knochens steuert (Davies 1996). Zudem wird die 
Anwesenheit von Osteocalcin als zuverlässiger Anhaltspunkt für eine fortgeschrittene Reifung von Osteoblasten angesehen (Ducy et al. 2000).

Allerdings wird die Osteocalcin-Expression von einer Reihe unterschiedlicher Faktoren beeinflusst, sodass der Osteocalcinspiegel interindividuell sehr stark variieren kann. So können sowohl Glukokortikoide als auch Schilddrüsenhormone die ermittelten Osteocalcinwerte beeinflussen (Beresford et al. 1984). Im Tierexperiment wurde gezeigt, dass bei Diabetes der Osteocalcingehalt in den Knochen sinkt (Thorwarth et al. 2005; Lu et al. 2003).

Die Funktionen des Osteocalcins sind daher insbesondere im Bereich der Mineralisierung und der Regulierung der Osteoklastenaktivität zu sehen.

\subsubsection{Thrombospondin-1 (TSP1)}

Zu den wichtigsten Funktionen des Thrombospondin-1 zählt die Regulation der Knochenmineralisierung und der Matrixproduktion und somit die Erhaltung der Homöostase (Ueno et al. 2006). Eine verminderte TSP1-Expression hat im Tierexperiment (an Mäusen) kraniofazialen Dysmorphismus ausgelöst (Nishiwaki et al. 2006).

Kürzlich wurde berichtet, dass Thrombospondin-1 über die Regulation des TGFbeta in die Differenzierung der Osteoblasten eingebunden ist (Bailey et al. 2012). Die Beobachtung von Amend und Kollegen, wonach bei Thrombospondin-1-Defizienz die Differenzierung und Aktivität der Osteoklasten reduziert ist, lässt annehmen, dass Thrombospondin-1 auch für die Entwicklung von Osteoklasten von entscheidender Bedeutung ist (Amend et al. 2015).

In Tumorzellen ist die Expression des Thrombospondin-1 unterdrückt (Shi et al. 2013). Das weist darauf hin, dass Thrombospondin-1 zumindest in schnell wachsenden und proliferierenden Zellen offenbar gegensätzlichere Funktionen ausübt als Osteopontin.

Die wichtigsten Funktionen des Thrombospondin-1 liegen demnach im Bereich des Erhalts der Homöostase und der normalen Entwicklung des Skeletts. 
Darüber hinaus ist Thrombospondin offenbar für die Differenzierung von Osteoblasten und -klasten wichtig.

\subsection{Zusammenfassende Analyse der Resultate}

Es bleibt festzuhalten, dass im Knochenmaterial, welches im Rahmen der vorgelegten Arbeit untersucht wurde, auf der einen Seite die Expression von Osteonektin und Thrombospondin steht - diese beiden Matrixproteine waren im Alveolarknochen deutlich stärker exprimiert als im Kieferwinkel (murine Proben) bzw. in der Tibia (humane Proben).

Auf der anderen Seite sind Osteopontin und Osteocalcin zu sehen. Diese beiden Proteine waren jeweils im Alveolarknochen wesentlich schwächer exprimiert als im Vergleichsmaterial (Kieferwinkel bzw. Tibia).

\begin{tabular}{|l|l|}
\hline Osteonektin & Thrombospondin-1 \\
\hline Erhalt der Balance & Erhalt der Homöostase \\
\hline $\begin{array}{l}\text { Normale Entwicklung des } \\
\text { Knochengerüsts }\end{array}$ & $\begin{array}{l}\text { Normale Entwicklung des } \\
\text { Skeletts }\end{array}$ \\
\hline $\begin{array}{l}\text { Bei Defizienz reduzierte } \\
\text { Osteoblasten und -klastenzahl }\end{array}$ & $\begin{array}{l}\text { Regulation der Osteoblasten- } \\
\text { Differenzierung }\end{array}$ \\
\hline $\begin{array}{l}\text { Marker für Differenzierung } \\
\text { osteogener Knochenzellen }\end{array}$ & $\begin{array}{l}\text { In Tumoren unterdrückte } \\
\text { Expression }\end{array}$ \\
\hline
\end{tabular}

Tab.5.1: Osteonektin und Thrombospondin-1: Wichtige Funktionen

Ausgehend von Gemeinsamkeiten bezüglich der Funktionen bzw. der Eigenschaften des Osteonektins und des Thrombospondins kann daher postuliert werden: Beide Proteine sind wichtig für den Erhalt der Homöostase und für die normale Entwicklung des Knochengerüsts (bei Defizienz treten morphologische Anomalien auf). Sowohl Osteonektin als auch Thrombospondin- 
1 sind in die Differenzierung von Osteoblasten (z. T. auch von Osteoklasten) eingebunden.

Der Umstand, dass keines dieser Matrixproteine in Tumorzellen aktiv ist, lässt darüber hinaus darauf schließen, dass diese beiden Proteine für den Erhalt der Merkmale schnelles Wachstum, intensive Proliferation, Motilität und Unsterblichkeit der Zelle nicht zwingend erforderlich sind.

Die relativ stärkere Ausprägung des Osteonektins und des Thrombospondin-1 im Alveolarknochen - worauf die Resultate der vorgelegten Studie hinweisen kann daher in dem Sinne interpretiert werden, dass dies dem Erhalt der Homöostase sowie der normalen Differenzierung der Osteoblasten und Osteoklasten und somit der normalen Entwicklung des Alveolarknochens dient.

\begin{tabular}{|l|l|}
\hline Osteopontin & Osteocalcin \\
\hline $\begin{array}{l}\text { Wesentliche Rolle bei } \\
\text { Mineralisierung und } \\
\text { Knochenresorption }\end{array}$ & $\begin{array}{l}\text { Wesentliche Rolle bei } \\
\text { Mineralisierung und } \\
\text { Knochenresorption }\end{array}$ \\
\hline $\begin{array}{l}\text { Ist auch in nicht mineralisierten } \\
\text { Geweben exprimiert; aktiviert } \\
\text { Überlebenssignalwege; spielt in } \\
\text { Tumoren eine wichtige Rolle }\end{array}$ & $\begin{array}{l}\text { Aktivierung der Osteoklasten } \\
\text { Expression ist u. a. abhängig von } \\
\text { Hormonen }\end{array}$ \\
\hline $\begin{array}{l}\text { Ist in die Immunabwehr } \\
\text { eingebunden }\end{array}$ & $\begin{array}{l}\text { Marker für fortgeschrittene } \\
\text { Reifung der Osteoblasten }\end{array}$ \\
\hline
\end{tabular}

Tab.5.2: Osteopontin und Osteocalcin: Wichtige Funktionen

Auch bei den beiden Matrixproteinen Osteopontin und Osteocalcin, die aufgrund unserer Resultate im Alveolarknochen in geringerem Maße vertreten waren als im Vergleichsknochen, sind gemeinsame Funktionen erkennbar. Die wesentliche Rolle beider Proteine ist offenbar im Bereich der Mineralisierung sowie im Bereich der Osteoklastenfunktion und der Knochenresorption angesiedelt. 
Die relativ schwächere Ausprägung dieser beiden Matrixproteine im Alveolarknochen könnte in dem Sinne interpretiert werden, dass der Alveolarknochen im Vergleich zu anderen Knochen eher für Störungen der Mineralisierung und Knochenresorption anfällig sein könnte; ebenso dürfte - bei vorhandener Osteopontin- oder Osteocalcindefizienz - die Aktivität und Motilität der Osteoklasten und somit auch das Knochenremodeling beeinträchtigt bzw. eingeschränkt sein. Ein zu geringer Osteopontingehalt dürfte auch die Entwicklung und Proliferation der Osteoblasten beeinträchtigen.

\subsection{Diskussion der Resultate}

Vorausgesetzt, dass die in der vorgelegten Arbeit ermittelten Resultate belastbar sind, wäre folgende Aussage über den Alveolarknochen im Vergleich zu anderen Knochen möglich:

Ein ausreichender, im Vergleich zu anderen Skelettknochen höherer Gehalt an Osteonektin und Thrombospondin-1 im Alveolarknochen weist auf ein stabiles Gleichgewicht zwischen Knochenabbau und -aufbau und auf eine ungestörte Entwicklung des Alveolarknochens hin.

Der Umstand, dass Osteopontin und Osteocalcin im Alveolarknochen schwächer vertreten sind als in anderen Skelettknochen, lässt darauf schließen, dass das Wachstum und die Proliferation sowohl der Osteoblasten als auch der Osteoklasten und insbesondere die Knochenresorption (und damit das "Startsignal" für Knochenumbau) sich in Grenzen hält. Es ist allerdings wichtig, dass der Gehalt dieser beiden Matrixproteine nicht unter eine bestimmte kritische Grenze fällt, da eine Osteopontin- und/oder Osteocalcindefizienz schwerwiegende Folgen für die Entwicklung des Knochens haben kann.

\subsubsection{Kritische Betrachtung der Methode}

Die Datenbasis der qRT-PCR-Analyse umfasste bis zu neun Einzelanalysen des jeweils von zehn gesunden Mäusen gewonnenen Knochenmaterials aus Alveolarknochen und Kieferwinkel. Die Zahl der angewendeten Tiere reicht aus, 
um das gewonnene, sorgfältig präparierte Material als repräsentativ ansehen zu können. Das gewählte Verfahren machte jedoch die Analyse des jeweils kompletten, homogenisierten Knochens erforderlich, sodass es nicht möglich war, lokale Unterschiede in der Konzentration der einzelnen Matrixproteine zu untersuchen.

Auf dieses Problem wurde in der Vergangenheit bereits hingewiesen (Bilbe et al. 1996): Aufgrund der erforderlichen Homogenisierung des Zellmaterials ist eine zellspezifische, scharf abgegrenzte Zuordnung und Lokalisierung der Expression extrazellulärer Matrixproteine nicht möglich. Zwar bietet die RT-PCR den Vorteil der Quantifizierung der Matrixproteine, die zellindividuelle Quantifizierbarkeit wird jedoch infrage gestellt (Bilbe et al. 1996). Je nach Mischungsverhältnis der Probe könnte demnach das Ergebnis unterschiedlich ausfallen.

In der vorliegenden Arbeit wurde zur Bestimmung der Pfaffl-Quotienten für jedes Matrixprotein jeweils das gleiche Probenmaterial verwendet; bei der Extraktion wurde auf die Auswahl reinen Knochenmaterials geachtet, sodass insbesondere durch anhaftendes Material keine Verfälschungen der quantitativen Analysen mittels RT-PCR zu erwarten waren.

Frank et al. (2002) weisen auf die erhebliche Komplexität der Knochenneubildung und der beteiligten Prozesse bei der Osteoblastenreifung hin. Dies bedeutet, dass einzelne extrazelluläre Matrixproteine, insbesondere Osteocalcin, zwar einen gewissen Anhaltspunkt für den Reifungsprozess darstellen, aufgrund der unbekannten Herkunft der Proteine jedoch keine eindeutigen Aussagen über das Stadium und den momentanen Zustand möglich sind.

Saffar et al. (1997) weisen auf die lokalen Auf- und Abbauprozesse im Alveolarknochen hin. Der Alveolarknochen befindet sich in einem stetigen Veränderungsprozess, wodurch die Migration der Zähne möglich wird. Bei einer Betrachtung mehrerer gesamthaft gewonnener muriner Alveolarknochen können jedoch die lokalen Unterschiede der an Knochenaufbauprozessen beteiligten Matrixproteine nicht berücksichtigt werden. Vor diesem Hintergrund sind die Ergebnisse der vorliegenden Arbeit dahin gehend zu betrachten, dass selbst im 
gesamthaft extrahierten Alveolarknochenmaterial deutlich unterschiedliche Gehalte extrazellulärer Matrixproteine im Vergleich zum Kieferwinkel festgestellt wurden. Daraus kann abgeleitet werden, dass in Alveolarknochen lokal auch erheblich höhere Konzentrationen vorliegen können.

Anhand von Rasterelektronenmikroskop-Aufnahmen von Knochenmaterial, das ex vivo auf entsprechend mit Matrix-Proteinen präparierte Träger aufgetragen wurde, zeigten Gramoun et al. (2010) die unterschiedlichen Teilungsraten, vor allem aber auch die verschiedenen, von den Matrixproteinen offensichtlich gesteuerten Wachstumsmorphologien.

Bennett et al. (2001) wiesen auf die spezifischen Einflüsse der Integrine auf die Osteoblastenreifung hin. Demnach steuern insbesondere Hydrocortison und Vitamin D3 über entsprechende Signalkaskaden die Integrinexprimierung und führen zu einer höheren Zelldifferenzierung, während der epidermale Wachstumsfaktor (EGF) die Reifung zwar fördert, jedoch eine ,schlankere' Differenzierung bewirkt. Die während der Reifung ausgeschütteten Integrine sind wiederum sehr vielfältig und lösen ihrerseits Signalkaskaden aus, die die Bildung extrazellulärer Matrixproteine induzieren (Bennett et al. 2001). Die Untersuchungen der vorliegenden Arbeit zeigen demnach das Resultat dieser Signalkaskaden während der Osteoblastenreifung.

In-vivo-Betrachtungen von Einheilungsprozessen, etwa von Implantaten, sind gegenwärtig nur anhand bildgebender Verfahren möglich. Analysen wie die qRT- PCR sind in vivo nur an extrahiertem Material durchführbar. Wegen der komplizierten Beschaffung geeigneten Probenmaterials ist eine Betrachtung der Expression entsprechender mRNA bzw. der Ausschüttung extrazellulärer Matrixproteine im Verlauf von Heilungsprozessen schwierig. Natürlich besteht die Möglichkeit, Zellkulturen anzulegen und diese als In-vitro-Modelle zu untersuchen. Die im vorhergehenden Abschnitt betrachteten Arbeiten von Khan et al. (2012) und Rausch-Fan et al. (2008) basierten auf solchen In-vitro-Ansätzen. 


\subsubsection{Limitationen}

Die Resultate der vorgelegten Arbeit basieren auf der Analyse der Expression ausgewählter Matrixproteine in murinen und humanen Proben aus Alveolar- und Referenzknochen. Da sich die Gewinnung ausreichender Mengen geeigneten Materials als sehr kompliziert erwies, mussten bestimmte methodische Limitationen in Kauf genommen werden.

Murines Knochenmaterial: Aufgrund der sehr geringen absoluten Mengen verfügbaren Knochenmaterials wurden die Alveolarknochen des Ober- und Unterkiefers vor der PCR-Analyse zusammengeführt und bei der weiteren Verarbeitung als einheitliche Proben behandelt. Daher kommen - neben den bereits erwähnten Problemen, die sich aus der erforderlichen Homogenisierung des Knochenmaterials ergeben - weitere offene Fragen hinzu, die für die ermittelten Resultate eventuell von Bedeutung sein könnten. So berichten Watabe et al. (2011), dass der Gehalt einiger Biomarker in Osteoblasten aus der Mandibula von jenem in Osteoblasten aus anderen Knochen häufig abweicht; auch bezüglich der Entwicklung der Osteoklasten und der RANKL-Produktion seien Unterschiede zwischen der Mandibula und den Referenzknochen beobachtet worden (Watabe et al. 2011) - wobei allerdings kein direkter Vergleich zwischen Mandibular- und Maxillarknochen vorgenommen wurde. Dennoch ist nicht völlig auszuschließen, dass bezüglich der in der vorliegenden Arbeit untersuchten extrazellulären Matrixproteine unterschiedliche Mengenverhältnisse im Alveolarknochen der Maxilla im Vergleich zur Manibula herrschen.

Humanes Knochenmaterial: Wie bereits im Kapitel "Material und Methoden“ dargelegt, wurden zur Analyse des humanen Alveolarknochens Reste des Tuber maxillae angewendet, die an extrahierten Weisheitszähnen anhafteten. Der Grund für die Extraktionen ist den zur Verfügung stehenden Patientendaten nicht zu entnehmen. Es ist daher nicht auszuschließen, dass im Bereich der Maxilla, aus dem die hier analysierten Proben stammen, inflammatorische Prozesse stattfanden, von denen unter Umständen der in der vorgelegten Arbeit untersuchte Alveolarknochen in Mitleidenschaft gezogen wurde. 
Bei der Beurteilung der Qualität bzw. Eignung der humanen Proben aus der Tibia könnten ähnliche Einschränkungen eine Rolle spielen. Die Proben stammen, wie bereits dargelegt, von Patienten, denen totale Knieendoprothesen implantiert wurden. Es ist deshalb anzunehmen, dass die betroffenen Patienten an fortgeschrittener Arthrose oder rheumatoider Arthritis litten. Beide Erkrankungen gehen mit chronischer Inflammation einher; bei rheumatoider Arthritis handelt es sich darüber hinaus um eine systemische Autoimmunkrankheit. Die Resultate der Analyse der Proben aus den humanen Tibiae sind daher mir einiger Vorsicht zu betrachten, da die Proben zwar von gesund erscheinenden Tibiae, jedoch nicht von gesunden Personen stammen. Ob bzw. inwieweit die gewonnenen Resultate durch diesen Umstand beeinflusst wurden, kann im Moment nicht beurteilt werden. 


\section{Schlussfolgerungen und Ausblick}

In der vorliegenden Arbeit wurde der Gehalt von vier extrazellulären Matrixproteinen (Osteocalcin, Osteopontin, Osteonektin und Thrombospondin-1) im Alveolarknochen mit dem Gehalt in einem Referenzknochenmaterial verglichen. Quantitativ war dies an murinem Knochenmaterial anhand der RT-PCR möglich; qualitativ wurde stichprobenartig an humanem Knochenmaterial geprüft, ob anhand mikroskopischer Analyse immunhistochemisch gefärbter Schnitte Resultate gewonnen werden können, die mit der Aussage der Resultate aus der qRTPCR-Analyse übereinstimmen.

\section{Murines Knochenmaterial}

Die Konzentrationen der einzelnen Matrixproteine im murinen Material wurden statistisch ausgewertet. Es ergaben sich signifikante Unterschiede bezüglich des Gehalts der untersuchten Matrixproteine im Alveolarknochen und im Referenzmaterial: Die mRNA-Konzentration des Osteocalcins im Alveolarbogen beträgt nur $30 \%$ der Konzentration dieses Matrixproteins im Kieferwinkel; der Osteopontingehalt des Alveolarknochens war bei einem Pfaffl-Ratio von nur 0,13 noch geringer. Dies könnte auf insgesamt niedrigere Kalzifizierungsraten im Alveolarknochen hinweisen. Eine langsamere Kalzifizierung kann durchaus von Vorteil für die mechanischen Eigenschaften des Knochens sein. Gleichzeitig weist der geringe Gehalt an Osteopontin darauf hin, dass das Zellwachstum und insbesondere die Proliferation - im Vergleich zum Kieferwinkel - im hier untersuchten Alveolarknochen gehemmt sind.

Zugleich fand sich im murinen Alveolarknochen ein praktisch verdoppelter Gehalt an Osteonektin (Pfaffl-Ratio: 1,96). Bei Heilungsprozessen, etwa nach Frakturen, sowie bei der Osseointegration von Implantaten spielen die mechanische Festigkeit und die gerichtete Struktur des Alveolarknochens eine entscheidende 
Rolle für die Tragfähigkeit der geheilten Zone respektive des eingeheilten Implantates. Hierbei ist ein hoher Gehalt an Osteonektin förderlich (Rotlland 2008).

Mit einer Pfaffl-Ratio von 7,5 wurde im murinen Alveolarknochen im Vergleich zum Kieferwinkel ein unerwartet hoher Gehalt an Thrombospondin-1 ermittelt. Die Funktion der Thrombospondine ist in verschiedenen Bereichen angesiedelt, insbesondere in der Regulierung der Knochenmineralisierung (Ueno et al. 2006) und der Differenzierung der Osteoklasten (Amend et al. 2015); auch wird innen eine ordnende Eigenschaft zugeschrieben (Masli et al. 2006; Contreras-Ruiz et al. 2013).

\section{Humanes Knochenmaterial}

Die Resultate der mikroskopischen Auswertung der immunhistochemisch gefärbten Schnitte aus humanen Proben stimmen bezüglich ihrer Aussage mit den Resultaten der RT-PCR-Analyse des murinen Materials überein. In dieser Beobachtung ist ein wichtiger Beitrag der vorliegenden Arbeit für künftige Studien mit ähnlicher Fragestellung zu sehen: Wie die vorliegenden Resultate belegen, ist es durchaus möglich, Vergleiche bezüglich des Gehalts extrazellulärer Matrixproteine in verschiedenen Knochenmaterialien sowohl anhand einer lichtmikroskopischen Analyse immunhistochemisch gefärbter histologischer Schnitte als auch anhand der qRT-PCR vorzunehmen.

Jedes der beiden verglichenen Verfahren hat seinen Vorteil und seinen Nachteil. Der Nachteil der mikroskopischen Auswertung beruht darin, dass die Resultate nur qualitativ, im optimalen Fall semiquantitativ, ausgewertet werden können. Dagegen besteht bei diesem Verfahren - im Vergleich zur RT-PCR - der große Vorteil, dass bei der mikroskopischen Analyse der Nachweis der analysierten Proteine den jeweiligen zellulären Strukturen zugeordnet werden kann. Dies ist gegenwärtig - durch die erforderliche Homogenisierung des Materials - anhand der PCR-Analyse nicht möglich. Die beiden Verfahren ergänzen sich daher auf sehr günstige Weise, was für künftige Studien mit ähnlicher Fragestellung von großer Bedeutung ist.

Bedeutung der Matrixproteine für die Implantatforschung 
Die gewonnenen Resultate sind auch ein wichtiger Beitrag für die Implantatforschung. Es ist erkennbar, dass beim Alveolarknochen bezüglich der Expression diverser extrazellulärer Matrixproteine im Vergleich zu anderen Skelettknochen individuelle Eigenschaften zu berücksichtigen sind. Die für eine erfolgreiche Osseointegration von Implantaten erforderliche mechanische Festigkeit und die gerichtete Struktur des Alveolarknochens hängen maßgeblich vom Gehalt einzelner, für diese Eigenschaften entscheidender Matrixproteine $a b$.

Die Frage, die gegenwärtig im Fokus der Implantatforschung steht - ob eine gezielte Supprimierung oder Steigerung der Expression bestimmter extrazellulärer Matrixproteine angestrebt werden sollte (und wenn ja, welcher) - ist nur aufgrund einer sorgfältigen Analyse der im gesunden, normalen Alveolarknochen exprimierten Matrixproteine und ihrer vielfachen Wechselwirkungen mit anderen Proteinen und davon abhängigen Signaltransduktionswegen zu beantworten. Hierzu bedarf es weitergehender Untersuchungen an umfangreicherem, qualitativ einwandfreiem Datenmaterial.

Diese Anforderungen sind leicht formuliert, in der Praxis jedoch nicht einfach realisierbar. So stellt insbesondere die Gewinnung geeigneter humaner Proben den Forscher vor schwer zu lösende Aufgaben. Um sich ein möglichst exaktes Bild von der Verteilung der Expression einzelner Proteine im Alveolarknochen machen zu können, sind getrennte Proben sowohl aus dem Alveolarknochen des Ober- als auch des Unterkiefers erforderlich. Als zuverlässiges Referenzmaterial soltten jeweils Proben von Skelettknochen des gleichen Donors dienen, da bei einigen Matrixproteinen interindividuelle Unterschiede beschrieben wurden. Natürlich steht auch die aus wissenschaftlicher Sicht berechtigte Forderung nach Proben aus gesunden Knochen von gesunden Donoren im Raum. 


\section{Zusammenfassung}

Die Osseointegration moderner Implantatoberflächen wird durch Matrixproteine gesteuert. In der vorliegenden Arbeit wurde die Expression extrazellulärer Matrixproteine im Alveolarknochen im Vergleich zum Referenzknochenmaterial untersucht, um zu klären, ob sich der Alveolarknochen hinsichtlich des Gehalts ausgewählter Matrixproteine (Osteonektin, Osteopontin Osteocalcin und Thrombospondin-1) von Skelettknochen unterscheidet.

Die vorgelegte Arbeit basiert auf den Resultaten zweier unterschiedlicher Herangehensweisen: In der ersten Phase wurden murine Proben aus dem Alveolarknochen im Vergleich zum Kieferwinkel anhand der qRT-PCR-Analyse ausgewertet und die Resultate einer quantitativen Analyse anhand der PfafflBerechnung unterzogen. In der zweiten Phase wurden humane Proben aus dem Alveolarknochen im Vergleich zu Proben aus der Tibia lichtmikroskopisch nach immunhistochemischer Färbung qualitativ ausgewertet. Die Resultate der quantitativen RT-PCR- und der qualitativen histochemischen Analyse wurden verglichen.

Anhand der qRT-PCR-Analyse wurde im Alveolarknochen ein Osteocalcin-Gehalt ermittelt, der gegenüber dem Kieferwinkel um den Faktor 0,294 geringer war (Pfaffl-Ratio). Der Osteopontingehalt im Alveolarknochen war mit einer Pfaffl-Ratio von nur 0,13 um einen Faktor $>7$ niedriger als im Kieferwinkel. Der Osteonektin-Gehalt im Alveolarknochen war gegenüber dem Kieferwinkel um den Faktor 1,9584 erhöht, der Thrombospondingehalt im Alveolarknochen war gegenüber dem Kieferwinkel sogar um den Faktor 7,551 erhöht.

Die im humanen Knochenmaterial gewonnenen qualitativen Resultate weisen bei allen verglichenen Matrixproteinen in die gleiche Richtung und bestätigen somit die Resultate aus den murinen Proben. Dies eröffnet für weitergehende vergleichende Studien des Matrixproteingehalts im Alveolarknochen die 
Möglichkeit einer sowohl quantitativen (qRT-PCR) als auch qualitativen (histochemisch) Auswertung.

Weitergehende, an größerem Material vorgenommene Untersuchungen sind erforderlich, um den Hinweis auf eine mögliche Sonderstellung des Alveolarknochens bezüglich der Expression einzelner extrazellulärer Matrixproteine zu überprüfen und evtl. zu erhärten. Dies könnte direkte Auswirkungen auf die aktuelle Implantatforschung, insbesondere im Hinblick auf Überlegungen einer gezielten Supprimierung oder Steigerung bestimmter Matrixproteine im Alveolarknochen, haben. 


\section{Verzeichnis der Abkürzungen}

\begin{tabular}{ll} 
Akt & Akt, Proteinkinase B; eine Serin/Threonin-Kinase \\
Arg & Arginin \\
Asp & Asparaginsäure \\
Bglap & Bone gamma carboxyglutamate protein \\
BM40 & SPARC/Osteonectin in der Basalmembran \\
BSP & Bone Sialoprotein \\
C57/BL6 & ein häufig angewendetes Mausmodell \\
CDNA & komplementäre DNA \\
EDTA & Etyhlendiamintetraessigsäure \\
EGF & Epidermal Growth Factor \\
Fab-Fragment & Fragment antigen binding; Antigen-bindendes Fragment \\
FAK & Focal Adhesion Kinase \\
Gly & Glycin \\
MAPK & Mitogen-activated protein kinases (MAPK) \\
ERK & Extracellular-signal Regulated Kinase \\
mRNA & messenger RNA \\
mTOR & mechanistic Target of Rapamycin, früher mammalian Target of \\
OC & Rapamycin \\
ON & Osteocalcin \\
OPN & Osteonectin, SPARC, Sparc \\
PI3K & Osteopontin \\
Rac & Phosphoinositid-3-Kinasen \\
& small G-Protein, Bestandteil verschiedener \\
& Signaltransduktionswege \\
\hline
\end{tabular}


RANKL Receptor Activator of NF-KB Ligand

RGD-Sequenz Aminosäuresequenz Arginin, Glycin und Asparaginsäure

RT-PCR Reverse Transkriptase-Polymerase-Kettenreaktion

SPARC Secreted protein acid and rich in cysteine, Osteonektin

TSP Thrombospondine 


\section{Verzeichnis der Tabellen}

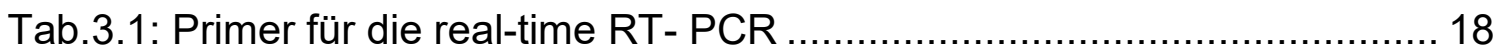

Tab.3.2: Pipettieransatz pro Gen und Well.......................................... 20

Tab.3.3: Verwendetes PCR-Programm des Mastercycler® ep realplex 2........ 21

Tab.4.1: Die PCR-Analysen für das Housekeeping-Gen im Alveolarknochen („Probe“) gegenüber dem Vorhandensein des Housekeeping-Gens im Kieferwinkel als Referenz ...................................................... 37

Tab.4.2: Die PCR-Analysen für Osteocalcin im Kieferwinkel als Referenz ....... 38

Tab.4.3: Die PCR-Analysen für Osteocalcin im Alveolarknochen .................... 38

Tab.4.4: Die PCR-Analysen für Thrombospondin im Kieferwinkel als Referenz 39

Tab.4.5: Die PCR-Analysen für Thrombospondin im Alveolarknochen ............. 40

Tab.4.6: Die PCR-Analysen für Osteonektin im Kieferwinkel als Referenz ....... 41

Tab.4.7: Die PCR-Analysen für Osteonektin im Alveolarknochen .................... 41

Tab.4.8: Die PCR-Analysen für Osteopontin im Kieferwinkel als Referenz....... 42

Tab.4.9: Die PCR-Analysen für Osteopontin im Alveolarknochen.................... 43

Tab.5.1: Osteonektin und Thrombospondin-1: Wichtige Funktionen................ 58

Tab.5.2: Osteopontin und Osteocalcin: Wichtige Funktionen ........................ 59 


\section{Verzeichnis der Abbildungen}

Abb.1.1: Das knöcherne Zahnfach (aus Wolf et al. 2003, S. 17) …................. 3

Abb.1.2: Osseointegration und fibroossäre Einheilung (aus Schwenzer und Ehrenfeld 2009, S. 232)............................................................. 5

Die Verwendung erfolgt mit Genehmigung der Thieme-Verlagsgruppe

Abb.1.3: Expression von Matrixproteinen durch Knochenbelegzellen (aus Alford und Hankenson 2006, S. 753)....................................... 9

Abb.3.1: Exemplarische Schmelzkurve einer Gradienten PCR. Ordinate: Fluoreszenzeinheiten (RFU)

Abb.3.2: Beispiel der Schmelzkurve einer Gradienten PCR. Ordinate: Änderung der Fluoreszenzintensität : -dl/dT (\%) ........................... 20

Abb.3.3: Standartkurve zur Bestimmung der Primereffizienz am Beispiel des Primers für das Gen Sparc 23

Abb.3.4: Abriss und Fraktur des Tuber maxillae (aus Schwenzer und Ehrenfeld 2009, S. 31): Der Knochen befindet sich noch am extrahierten Weisheitszahn.

Die Verwendung erfolgt mit Genehmigung der Thieme-Verlagsgruppe

Abb.4.1: PCR-Schmelzkurven zur Bestimmung des Gehaltes an Protein Bglap1 im Alveolarknochen und im Kieferwinkel als Referenz ......... 33

Abb.4.2: PCR-Schmelzkurven zur Bestimmung des Gehaltes an Protein Thbs1 im Alveolarknochen und im Kieferwinkel als Referenz

Abb.4.3: PCR-Schmelzkurven zur Bestimmung des Gehaltes an Protein Sparc im Alveolarknochen und im Kieferwinkel als Referenz 35

Abb.4.4: PCR-Schmelzkurven zur Bestimmung des Gehaltes an Osteopontin im Alveolarknochen und im Kieferwinkel als Referenz 36

Abb.4.5: Humaner Tuber maxillae, Schnitt und Osteocalcin-Färbung (10-fache Vergrößerung) 44

Abb.4.6: Humaner Tuber maxillae, Schnitt und Osteocalcin-Färbung (40-fache Vergrößerung)

Abb.4.7: Humaner Tibiaknochen, Schnitt und Osteocalcin-Färbung (10-fache Vergrößerung). 
Abb.4.8: Humaner Tibiaknochen, Schnitt und Osteocalcin-Färbung (40-fache Vergrößerung). 46

Abb.4.9: Humaner Tuber maxillae, Schnitt und Osteonektin-Färbung (4-fache Vergrößerung) 47

Abb.4.10: Humaner Tuber maxilae, Schnitt und Osteonektin-Färbung (10-fache Vergrößerung) 47

Abb.4.11: Humane Tuber maxillae, Schnitt und Osteonektin-Färbung (40-fache Vergrößerung) 48

Abb.4.12: Humaner Tibiaknochen, Schnitt und Osteonektin-Färbung (40-fache Vergrößerung) 48

Abb.4.13: Humaner Tuber maxilae, Schnitt und Osteopontin-Färbung (10-fache Vergrößerung) 49

Abb.4.14: Humaner Tuber maxillae, Schnitt und Osteopontin-Färbung (40-fache Vergrößerung) 50

Abb.4.15: Humaner Tibiaknochen, Schnitt und Osteopontin Färbung (40-fache Vergrößerung) 51 


\section{Literaturverzeichnis}

Alford AI, Hankenson KD (2006): Matricellular proteins: Extracellular modulators of bone development, remodeling and regneration. Bone $\underline{38}, 749-$ 757

Amend SR, Uluckan O, Hurchla M, Leib D, Novack DV silva M, Frazier W, Weilbaecher KN (2015): Thrombospondin-1 regulates bone homeostasis through effects on bone matrix integrity and nitric oxide signaling in osteoclasts. J Bone Miner Res $\underline{30}, 106-15$

Anderson JM (2001): Biological responses to materials. Annu Rev Mater Res $\underline{31}, 81-110$

Armstrong LC, Bornstein P (2003): Thrombospondins 1 and 2 function as inhibitors of angiogenesis. Matrix Biol 22, 63-71

Asch AS, Silbiger S, Heimer E, Nachman RL (1991): CD36-transfected Jurkat cells bind thrombospondin via a malaria-homologous domain. Clin Res $\underline{39}$, A338

Bailey DK, Zayzafoon M, Murphy-Ullrich JE (2012): Thrombospondin-1 inhibits osteogenic differentiation of human mesenchymal stem cells through latent TGF- $\beta$ activation. Biochem Biophys Res Commun $\underline{422}$, 488-93

Bennett JH, Carter DH, Alavi AL, Beresford JN, Walsh S (2001): Patterns of integrin expression in a human mandibular explant model of osteoblast differentiation. Arch Oral Biol $\underline{46}, 229-238$

Beresford JN, Gallagher JA, Poser JW, Russell RG (1984) Production of osteocalcin by human bone cells in vitro. Effects of 1,25(OH)2D3, 24,25(OH)2D3, parathyroid hormone, and glucocorticoids. Metab Bone Dis 
Relat Res $\underline{5}, 229-234$

Bilbe G, Roberts E, Birch M, Evans DB (1996): PCR phenotyping of cytokines, growth factors and their receptors and bone matrix proteins in human osteoblast-like cell lines. Bone $\underline{19}$, 437-445

Bornstein P (1995): Diversity of function is inherent in matricellular proteins: an appraisal of thrombospondin 1. J Cell Biol 130, 503-506

Bornstein P (2001): Thrombospondins as matricellular modulators of cell function. J Clin Invest 107, 929-934

Bornstein P, Sage EH (1994): Thromospondins. Methods Enzymol 245, $62-85$

Bornstein P, Agah A, Kyriakides TR (2004): The role of thrombospondins 1 and 2 in the regulation of cell-matrix interactions, collage fibril formation, and the response to injury. IJBCB $\underline{36}, 1115-1125$

Bradshaw AD, Sage EH (2001): SPARC, a matricellular protein that functions in cellular differentation and tissue response to injury. J Clin Invest 107, 1049-1054

Brånemark PI, Hansson BO, Adell R, Breine U, Lindström J, Hallen O, Ohmann A (1977): Osseointegrated implants in the treatment of the edentulous jaw. Experience from a 10-year period. Scand J of Plast Reconstr Surg Suppl 16, 1132

Carron JA, Wagstaff SC, Gallagher JA, Bowler WB (2000): A Cd36-binding peptide from thrombospondin-1 can stimulate resorption by osteoclasts in vitro. Biochem Biophys Res Commun 270, 1124-1127

Chabas D (2005): Osteopontin, a multi-faceted molecule. Med Sci (Paris) $\underline{21,832-838}$ 
Chellaiah MA, Kizer N, Biswas R, Alvarez U, Strauss-Schoenberger J, Rifas L, Rittling SR, Denhardt DT, Hruska KA (2003): Osteopontin Deficiency Produces Osteoclast Dysfunction Due to Reduced CD44 Surface Expression. Mol Biol Cell $14,173-189$

Chen CS, Mrksich M, Huang S, Whitesides GM, Ingber DE (1997): Geometric control of cell life and death. Science $\underline{276}, 1425-1428$

Cohen M, Joester D, Geiger B, Addadi L (2004): Spatial and temporal sequence of events in cell adhesion: from molecular recognition to focal adhesion assembly. Chembiochem $\underline{5}, 1393-1399$

Contreras-Ruiz L, Regenfuss B, Mir FA, Kearns J, Masli S (2013): Conjunctival Inflammation in Thrombospondin-1 Deficient Mouse Model of Sjögren's Syndrome. PLoS ONE 즈, e75937

Cowles EA, DeRome ME, Pastizzo G, Brailey LL, Gronowiez GA (1998): Mineralization and the expression of matrix proteins during in vivo bone development. Calcif Tissue Int $\underline{62}, 74-82$

Danen EH, Sonnenberg A (2003): Integrins in rgulation of tissue development and function. J Pathol 201, 632-641

Davies JE (1996). In vitro modeling of the bone/implant interface. Anat Rec. $\underline{45}$, 426-445

Delany AM, Amling M, Priemel M, Howe C, Baron R, Canalis E (2000): Osteopenia and decreased bone formation in Osteonektin-deficient mice. J Clin Invest $\underline{105}$, 915-923 
Delany AM, Kalajzic I, Bradshaw AD, Sage EH, Canalis E (2003): Osteonetinnull mutation compromises osteoblast formation, maturation, and survival. Endocrinology 144 , 2588-2596

Ducy P, Desbois C, Boyce B, Pinero G, Story B, Dunstan C, Smith E, Bonadio J, Goldstein S, Gundberg C, et al. (1996): Increased bone formation in osteocalcin- deficient mice. Nature $\underline{382}, 448-452$

Ducy P, Schinke T, Karsenty G (2000): The osteoblast: a sophisticated fibroblast under central surveillance. Science $\underline{289}, 1501-1504$

Eckelt U, Pilling E, Mai R, Huhle M, Bierbaum S, Bernhardt R, Scharnweber D, Kuhlisch E, Hempel U, Stadlinger B (2007): Beschleunigte Osseointegration durch Implantatbeschichtungen mit Bestandteilen der extrazellularen Matrix. Z Zahnärztl Impl $\underline{23}, 101-111$

Felding- Habermann B, Cheresh DA (1993): Vitronectin and its receptors. Curr Opin Cell Biol $\underline{5}, 864-868$

Felsenberg D: Stützwerk aus Kollagen und Hydroxylapatit - Struktur und Funktion des Knochens. In: Deutsche Pharmazeutische Gesellschaft (Hrsg.): Pharmazie in unserer Zeit. Band 30, Ausgabe 6, Wiley VCH Verlag, Weinheim 2001

Ferron M, Hinoi E, Karsenty G, Ducy P (2008): Osteocalcin differentially regulates beta cell and adipocyte gene expression and affects the development of metabolic diseases in wild-type mice. Proc Natl Acad Sci USA 105, 52665270

Frank O, Heim M, Jakob M, Barbero A, Schafer D, Bendik I, Dick W, Heberer M, Martin I (2002): Real-time quantitative RT-PCR analysis of human bone marrow 
stromal cells during osteogenic differentiation in vitro. J Cell Biochem $\underline{85,737-}$ 746

Franzén A, Heinegård D (1985): Isolation and characterzation of two sialoproteins present only in bone calcified matrix. Biochem J 232, 715-724

Garcia AJ (2005): Get a grip: integrins in cell-biomaterial interactions. Biomaterial $\underline{26}, 7525-7529$

Giachelli CM, Streitz S (2000): Osteopontin: a versatile regulator of inflammation and biomineralization. Matrix Biol $\underline{19}, 615-622$

Giancotti FG, Ruoslathi E (1999): Integrin signaling. Science 285, 1028-1032

Goldberg HA, Hunter GK (1995): The inhibitory activity of osteopontin on hydroxyapatite formation in vitro. Ann N Y Acad Sci $\underline{760}$, 305-308

Gramoun A, Goto T, Nordström T, Rotstein OD, Grinstein S, Heersche JNM, Manolson MF(2010): Bone Matrix Proteins and Extracellular Acidification:

Potential Co-Regulators of Osteoclast Morphology. Journal of Cellular Biochemistry 111, 350-361

Hauschka PV, Lian JB, Cole DE, Gundberg CM (1989): Osteocalcin and matrix Gla protein: vitamin K dependent proteins in bone. Physiol Rev $\underline{69}$, 990-1047

Hynes RO (2002): Integrins: Bidirectional, allosteric signaling machines. Cell 110, 673-687 
Ihara H, Denhardt DT, Furuya K, Yamashita T, Muguruma Y, Tsuji K, Hruska KA, Higashio K, Enomoto S, Nifuji A, et al. (2001): Parathyroid hormone-induced bone resorption does not occur in the absence of osteopontin. J Biol Chem $\underline{276}$, 13065-13071

Khan MR, Donos N, Salih V, Brett PM (2012): The enhanced modulation of key bone matrix components by modified Titanium implant surfaces. Bone. $\underline{50}, 1-8$

Lane TF, Sage EH (1994): The biology of SPARC, a protein that modulates cellmatrix interactions. FASEB J $\underline{8}, 163-173$

Lawler J, Hynes RO (1989): An integrin receptor on normal and thrombasthenic platelets that bind thrombospondin. Blood 74, 2022-2027

Lehmann KM, Hellwig E, Wenz HJ: Zahnärztliche Propädeutik: Einführung in die Zahnheilkunde. 11. Auflage; Deutscher Zahnärzte Verlag, Köln 2008

Lu H, Kraut D, Gerstenfeld LC, Graves DT. (2003) Diabetes interferes with the bone formation by affecting the expression of transcription factors that regulate osteoblast differentiation. Endocrinology 144, 346-352

Mackie EJ, Murphy LI (1998): The role of tenascin-C and related glycoproteins in early chondrogenesis. Microsc Res Tech $\underline{43}, 102-110$

Masli S, Turpie B, Streilein JW (2006) Thrombospondin orchestrates the tolerance-promoting properties of TGFbeta-treated antigenpresenting cells. Int Immunol 18, 689-699 
McKee MD, Nanci A (1995): Osteopontin and the bone remodeling sequence: Colloid-gold immunocytochemistry of an interfacial extracellular matrix protein. Ann N Y Acad Sci $\underline{760}, 177-189$

Morrison TB, Weis JJ, Wittwer CT (1998): Quantification of low-copy transcripts by continuous SYBR Green I monitoring during amplification. Biotechniques $\underline{24}$, 954-958

Nishiwaki T, Yamaguchi T, Zhao C, Amano H, Hankenson KD; Bornstein P, Toyama Y, Matsuo K (2006): Reduced expression of thrombospondins and craniofacial dysmorphism in mice overexpressing Fra1. J Bone Miner Res $\underline{21}$, 596-604

Oldberg A, Franzén A, Heinegård D (1986): Cloning and sequence analysis of rat bone sialoprotein (osteopontin) CDNA revels an arg-gly-asp cell-binding sequence. Proc Natl acad Sci USA $\underline{83}$, 8819-8823

Oury F, Sumara G, Sumara O, Ferron M, Chang H, Smith CE, Hermo L, Suarez S, Roth BL, Ducy P, et al. (2011): Endocrine regulation of male fertility by the skeleton. Cell 144, 796-809

Pfaffl MW (2001): A new mathematical model for relative quantification in realtime RT-PCR. Nucleic Acids Res $\underline{9}$, e45

Price PA, Williamson MK (1981): Effects of warfarin on bone. Studies on the vitaminK-dependant protein in rat bone. J Biol Chem 256, 12754-12759

Prince CW, Butler WT (1987): 1,25 Dihydroxyvitamin D3 regulates the biosynthesis of osteopontin, a bone-derived cell attachment protein, in clonal osteoblast-like osteosarcoma cells. Collagen Rel Res $\underline{7}, 305-313$ 
Ram VS, Parthiban, Sudhakar U, Mithradas An Prabhakar R (2015):

Bonebiomarkers in periodontal disease: a review article. J Clin Diagn Res $\underline{9}, 7$ 10

Rausch-Fan X, Qu Z, Wieland M, Matejka M, Schedle A (2008): Differentiation and cytokine synthesis of human alveolar osteoblasts compared to osteoblast like cells in response to titanium surfaces. Dent Mater $\underline{24}, 102-110$

Robertson BW, Bonsal L, Chellaiah MA (2010): Regulation of Erk1/2 activation by osteopontin in PC3 human prostate cancer cells. Molecular Cancer $\underline{9}, 260-$ 270

Rodan SB, Rodan GA (1997): Integrin function in osteoclasts. J Endocrinol 154, $47-56$

Ross FP, Chappel J, Alvarez JI, Sander D, Butler WT, Farach- Carson MC, Mintz KA, Robey PG (1993): Interactions between the Bone Matrix ProteinsOsteopontin and Bone Sialoprotein and the Osteoclast Integrin avß3 Potentiate Bone Resorption. J Biol Chem 268, 9901-9907

Rotllant J, Liu D, Yan YL, Postlethwait JH, Westerfield M, Du SJ (2008): Sparc (Osteonektin) functions in morphogenesis of the pharyngeal skeleton and inner ear. Matrix Biology 27, 561-572

Saffar JL, Lasfargues JJ, Cherruau SM (1997): Alveolar bone and the alveolar process: the socket that is never stable. Periodontology $2000 \underline{13}, 76-90$

Sage EH, Bornstein P (1991): Extracellular Proteins That Modulate Cell-Matrix Interactions: SPARC, tenascin and thrombospondin. J Biol Chem $\underline{266}, 14831-$ 14834 
Shi X, Deepak V, Wang L, Ba X Komori T, Zeng X, Liu W (2013):

Thrombospondin-1 is a putative target gene of Runxx2 and Runx3. Int J Mol Sci 14, $14321-14332$

Schwenzer N, Ehrenfeld M: Zahnärztliche Chirurgie (Zahn-MundKieferheilkunde). 4. Auflage; Georg Thieme Verlag, Stuttgart 2009

Shekaran A, Garcia AJ (2010): Extracellular matrix-mimetic adhesive biomaterilas for bone repair. J Biomed Mater Res A $\underline{96}$, 261-272

Sodek J, McKee MD (2000): Molecular and cellular biology of alveolar bone. Periodontology $2000 \underline{24}, 99-126$.

Sodek J, Ganss B, McKee MD (2000): Osteopontin. Crit Rev Oral Biol Med 11, 279-303

Stanford CM, Keller JC (1991): The concept of osseointegration and bone matrix expression. Crit Rev Oral Biol Med 2 2, 83-101

Streit M, Velasco P, Brown LF, Skobe M, Richard L, Riccardi L, Lawler J, Detmar M (1999): Overepresion of thrombospondin-1decreases angiogenesis and inhibits the growth of human cutaneous squamous cell carcinomas. Am J Pathol $\underline{155}$, 441-452

Termine JD, Kleinmann HK, Whitson SW, Conn KM, McGarvey ML, Martin GR (1981): Osteonektin, a bone-specific protein linking mineral to Collagen. Cell $\underline{26}$, 99-105 
Thorwarth M, Rupprecht S, Falk S, Felszeghy E, Wiltfang J, Schlegel KA (2005): Expression of bone matrix proteins during de novo bone formation using a bovine collagen and platelet-rich plasma (prp)--an immunohistochemical analysis. Biomaterials $\underline{26}, 2575-2584$

Ueno A, Miwa Y, Miyoshi K, Horiguchi T, Inoue H, Ruspita I, Abe K, Yamashita K, Hayashi E, Noma T (2006): Constitutive Expression of Thrombospondin 1 in MC3T3-E1 Osteoblastic cells inhibit mineralization. J Cell Physiol 209, 322-332

Watabe H, Furuhama T, Tani-Ishii N, Mikuni-Takagaki Y (2011):

Mechanotransduction activates $\alpha_{5} \beta_{1}$ integrin and PI3K/Akt signaling pathways in mandibular osteoblasts. Experimental Cell Research $\underline{317}$, 2642-2649

Weber GF, Ashkar S, Glimcher MJ, Cantor H (1996): Receptor-ligand interaction between CD44 and osteopntin(Eta-1). Science 271, 509-512

Welsch U: Sobotta Lehrbuch Histologie. 2. Auflage; Urban \& Fischer Verlag, München 2006

Wigfield C, Robertson J, Gill S, Nelson R (2003): Clinical experience with porous tantalum cervical interbody implants in a prospective randomized controlled trial. Br J Neurosurg 17, 418-425

Wolf HF, Rateitschak KH, Rateitschak EM: Parodontologie. Farbatlanten der Zahnmedizin. Bd. 1, 3. Auflage; Thieme Verlag, Stuttgart 2003 


\section{Danksagung}

Mein besonderer Dank gilt Herrn Prof. Dr. med. Nicolai Miosge, der mir mit viel Geduld und seiner sehr guten Betreuung die Erstellung dieser Arbeit erst ermöglicht hat. Ebenso möchte ich mich bei allen jetzigen und ehemaligen Mitarbeitern der Arbeitsgemeinschaft orale Biologie und Geweberegenration bedanken, die mir bei offenen Fragen immer weitergeholfen haben. 


\section{Lebenslauf}

Als zweites Kind von Christel und Werner Große Steffen wurde ich am 1. Februar 1983 in Salzgitter- Lebenstedt geboren.

Ab 1989 besuchte ich die katholische Grundschule St. Michael und seit 1993 die Orientierungsschule An der Schölke in Salzgitter.

Das Kranich- Gymnasium in Salzgitter besuchte ich seit 1995, an welchem ich 2002 mit dem Abitur die Allgemeine Hochschulreife erlangte.

Mit Beginn des Wintersemesters 2002/2003 studierte ich für sechs Semester Rechtswissenschaften an der Georg- August- Universität in Göttingen.

Zum Wintersemester 2005/2006 wechselte ich in den Studiengang der Zahnmedizin, welchen ich 2010 mit dem Staatsexamen erfolgreich abschließen konnte.

Nach Erteilung der Approbation begann ich im Frühjahr 2011 meine Assistenzzeit in der Praxis von Gunda und Klaus- Dirk Schumann in Goslar.

Nach sechs Monaten führte ich diese in Goslar in der Praxis Dr. Belger und Kollegen zu Ende, wo ich seit 2013 als Zahnarzt tätig bin. Am 31. Mai 2014 wurde mein Sohn Moritz Große Steffen geboren. Die Mutter von Moritz, Frau Nadine Hoppe, habe ich am 1. Juni 2015 geheiratet. 